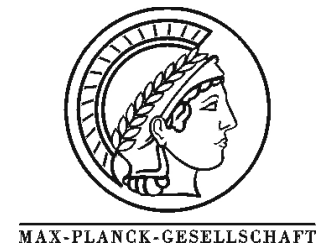

Originally published as:

"Methanol Steam Reforming"

Malte Behrens and Marc Armbrüster

Chapter 5, 2012, 175-235

DOI: $10.1007 / 978-1-4614-0344-95$

In: Catalysis for Alternative Energy Generation.

Edited by Guczi, László; Erdôhelyi, András

2012, XIII, 536 p. 185 illus., 48 in color., Hardcover

Copyright (C) Springer Science+Business Media New York 2012

ISBN: 978-1-4614-0343-2 


\title{
Methanol Steam Reforming
}

\author{
Malte Behrens ${ }^{a}$,* and Marc Armbrüster ${ }^{\mathrm{b}}$ \\ a. Department of Inorganic Chemistry, Fritz-Haber-Institute, Faradayweg 4-6, 14196 \\ Berlin, Germany \\ b. Max-Planck-Institut für Chemische Physik fester Stoffe, Nöthnitzer Strasse 40, 01187 \\ Dresden, Germany \\ * email: behrens@fhi-berlin.mpg.de, Tel: +49 3084134408
}

\section{Outline}

Catalysis: Alternative Energy Generation - Methanol Steam Reforming .....................................................................................1

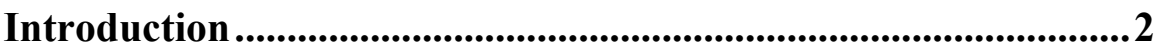

Cu-based Catalysts for Methanol Steam reforming .......................8

General aspects of $\mathrm{Cu} / \mathrm{ZnO}$-based catalysts .............................. 10

Drawbacks of $\mathrm{Cu} / \mathrm{ZnO}$-based catalysts ..................................... 14

Preparation of $\mathrm{Cu} / \mathrm{ZnO}$-based catalysts ..................................... 21

Ternary $\mathrm{Cu} / \mathrm{ZnO} / \mathrm{X}$ catalysts $\left(\mathrm{X}=\mathrm{Al}_{2} \mathrm{O}_{3}, \mathrm{ZrO}_{2}\right) \ldots \ldots \ldots \ldots \ldots \ldots . . . . . . . . . . . .32$

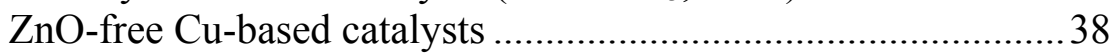

The active form of $\mathrm{Cu}$ under MSR conditions ............................43

Intermetallic Compounds in Methanol Steam Reforming.........51

Catalysts derived by decomposition of intermetallic compounds 57

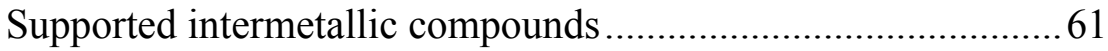

Unsupported intermetallic compounds.................................... 76 


\section{Introduction}

The currently increasing interest in catalytic reactions of methanol, $\mathrm{CH}_{3} \mathrm{OH}$, is - in addition to its customary role as an important base chemical and feedstock for value-added molecules - due to its potential as a chemical storage molecule for hydrogen. Methanol is industrially produced from natural gas- or coal-derived syngas, but can in principle also be synthesized from $\mathrm{CO}_{2}$ by hydrogenation [1]. It is suggested by Olah et al. [2] as a " $\mathrm{CO}_{2}$-neutral" combustion fuel in the context of the so-called methanol economy or can be used in direct methanol fuel cells (DMFC) for generation of electric power. Methanol might thus play a key role in the transition towards a future energy scenario, which has to be more and more independent from fossil sources [3].

The main advantage of using methanol for chemical instead of physical storage of hydrogen is related to its decentralized use of hydrogen, e.g. in the transportation sector. Methanol is a very attractive onboard hydrogen source for polymer electrolyte fuel cells (PEMFC) in mobile applications like automobiles as it circumvents the problems of physical storage and distribution of hydrogen such as the necessity of pressurized or cryogenic containers. Methanol is liquid at ambient conditions and can be safely distributed using pipelines and conventional filling station infrastructure. It has a high $\mathrm{H}: \mathrm{C}$ ratio of 4:1 and no C-C bond, which has to be broken.

There are several catalytic reactions available for liberating hydrogen from methanol: 
Methanol decomposition (MD):

$$
\mathrm{CH}_{3} \mathrm{OH} \rightarrow \mathrm{CO}+2 \mathrm{H}_{2} \quad \Delta \mathrm{H}^{0}=90 \mathrm{~kJ} / \mathrm{mol}(1)
$$

Methanol steam reforming (MSR):

$$
\mathrm{CH}_{3} \mathrm{OH}+\mathrm{H}_{2} \mathrm{O} \rightarrow \mathrm{CO}_{2}+3 \mathrm{H}_{2} \quad \Delta \mathrm{H}^{0}=49 \mathrm{~kJ} / \mathrm{mol}(2)
$$

Partial oxidation of methanol (POM):

$$
\mathrm{CH}_{3} \mathrm{OH}+0.5 \mathrm{O}_{2} \rightarrow \mathrm{CO}_{2}+2 \mathrm{H}_{2} \quad \Delta \mathrm{H}^{0}=-155 \mathrm{~kJ} / \mathrm{mol}(3)
$$

Furthermore, the water gas shift (WGS) and reverse WGS (rWGS) reactions have to be considered:

$$
\mathrm{CO}+\mathrm{H}_{2} \mathrm{O} \rightarrow \mathrm{CO}_{2}+\mathrm{H}_{2} \quad \Delta \mathrm{H}^{0}=-41 \mathrm{~kJ} / \mathrm{mol}(4)
$$

Among these reactions, MSR seems to be most attractive as it generates the highest hydrogen concentration in the product stream, runs at relatively low temperatures of $500-600 \mathrm{~K}$, and does not directly produce $\mathrm{CO}$, which acts as a poison for the downstream PEMFC anode catalyst. MSR was first described in 1921 by J. A. Christiansen [4] and research on its application for hydrogen production has a long history [5]. The recently renewed interest was triggered by the development of fuel cell technology requiring clean and preferably renewable hydrogen. A number of general overview articles and reviews are available addressing the role of MSR in this context [e.g. 
5-11]. MSR is an endothermic reaction and requires external heating. It is sometimes used in combination with exothermic POM (autothermal reforming or oxidative steam reforming) $[12,13]$ or combustion of methanol [8] in order to generate the necessary heat. However, the endothermicity of MSR is much weaker compared to steam reforming of other hydrocarbons or higher alcohols [8] and reformer units can be relatively small enabling the onboard combination with PEMFCs. Several prototype vehicles that run on hydrogen fuel cell technology have already been developed by different companies. A comparison between methanol and other molecules as reactants for onboard hydrogen production can be found in the comprehensive review by Palo et al. and in the references therein [11].

This chapter will focus mainly on the challenges of catalyst development for MSR. The requirements for a good MSR catalyst to be used for onboard hydrogen production in combination with PEMFCs are the following:

- The catalyst should be highly selective to $\mathrm{CO}_{2}$ and minimize the $\mathrm{CO}$ content in the hydrogen-rich product gas stream, which acts as a poison for PEMFC anodes.

- It should be active at low temperatures to be efficient and to disfavor the rWGS reaction as a source of CO.

- Its components should be abundant and of low cost and its preparation should be facile and scalable. 
- It should be stable at extended time on stream, i.e. resistant to coke formation, stable against sintering and tolerant towards catalyst poisons.

- In particular, it should be stable towards abrupt changes of the conditions of reforming, i.e. work reliably in transient situations like on-off operations as well as in steady state to produce sufficient amounts of hydrogen on demand.

The detrimental role of $\mathrm{CO}$ in the effluent for the downstream PEMFC is to be emphasized. CO chemisorbs irreversibly on the typically Pt-based fuel cell catalysts and causes irreversible site blocking. Its concentration has to be below ca. $20 \mathrm{ppm}$ in order to prevent poisoning, which is usually not achieved in the reformer outlet gas. Thus, in technical applications, a gas purification step has to be introduced between reformer and fuel cell. The $\mathrm{CO}$ concentration in the gas stream can lowered by means of preferential oxidation (PROX) or using Pd membranes, which in both cases complicates the setup and generates costs [14]. Generally, a low selectivity to CO - in addition to high activity and stability - is, thus, a major and particular requirement for a successful MSR catalyst.

This chapter is divided into two parts treating different families of catalytic materials active in the MSR reaction. The first part covers the widely studied $\mathrm{Cu}$-based catalysts, while the second part will focus on the role of intermetallic compounds in MSR. Some catalytic 
data from the literature for the MSR reaction over selected catalysts treated in this chapter is compiled in Table 1.

Tab. 1: Comparison of catalytic performance in (oxidative) MSR of selected catalyst systems covered in this contribution. Note possible difference in feed gas composition and contact time of the experiments. Some values were re-calculated from the data given in the original references.

\begin{tabular}{|c|c|c|c|c|c|c|c|}
\hline Catalyst & $\begin{array}{l}\text { Pre- } \\
\text { treatment }^{a}\end{array}$ & $\begin{array}{l}\text { Conver- } \\
\text { sion / \% }\end{array}$ & $\begin{array}{l}\mathrm{CO}_{\mathrm{x}} \text { for- } \\
\text { mation / } \\
\%\end{array}$ & $\begin{array}{l}\mathbf{H}_{2} \text { produc- } \\
\text { tion rate / } \\
\mathbf{L g}^{-1} \mathbf{h}^{-1}\end{array}$ & $\mathbf{T} / \mathbf{K}$ & Remarks $^{\text {b }}$ & Ref. \\
\hline \multirow[t]{2}{*}{$43.8 \% \mathrm{Cu} / \mathrm{ZnO}$} & C623 & \multirow[t]{2}{*}{90} & \multirow[t]{2}{*}{$0.14^{\mathrm{c}}$} & \multirow[t]{2}{*}{ - } & \multirow[t]{2}{*}{582} & \multirow[t]{2}{*}{ (Co-ppt.) } & \multirow[t]{2}{*}[15]{} \\
\hline & R523 & & & & & & \\
\hline \multirow{2}{*}{$\begin{array}{l}39.4 \% \\
\mathrm{Cu} / \mathrm{ZnO} / \mathrm{Al}_{2} \mathrm{O}_{3}\end{array}$} & C623 & \multirow[t]{2}{*}{90} & \multirow[t]{2}{*}{$0.11^{\mathrm{c}}$} & \multirow[t]{2}{*}{-} & \multirow[t]{2}{*}{579} & \multirow[t]{2}{*}{ (Co-ppt.) } & \multirow[t]{2}{*}{ [15] } \\
\hline & R573 & & & & & & \\
\hline \multirow{2}{*}{$\begin{array}{l}32.3 \% \\
\mathrm{Cu} / \mathrm{ZnO} / \mathrm{ZrO}_{2}\end{array}$} & C623 & \multirow[t]{2}{*}{90} & \multirow[t]{2}{*}{$0.05^{\mathrm{c}}$} & \multirow[t]{2}{*}{-} & \multirow[t]{2}{*}{567} & \multirow[t]{2}{*}{ (Co-ppt.) } & \multirow[t]{2}{*}[15]{} \\
\hline & R573 & & & & & & \\
\hline \multirow{2}{*}{$\begin{array}{l}30.9 \% \\
\mathrm{Cu} / \mathrm{ZnO} / \mathrm{Al}_{2} \mathrm{O}_{3} / \mathrm{ZrO}_{2}\end{array}$} & $\mathrm{C} 623$ & \multirow[t]{2}{*}{90} & \multirow[t]{2}{*}{$0.05^{\mathrm{c}}$} & \multirow[t]{2}{*}{-} & \multirow[t]{2}{*}{551} & \multirow[t]{2}{*}{ (Co-ppt.) } & \multirow[t]{2}{*}{ [15] } \\
\hline & R573 & & & & & & \\
\hline \multirow[t]{2}{*}{$\mathrm{Cu} / \mathrm{ZnO} / \mathrm{Al}_{2} \mathrm{O}_{3}$} & $\mathrm{C} 723$ & \multirow[t]{2}{*}{90} & \multirow[t]{2}{*}{$<0.05^{\mathrm{c}}$} & 38.4 & 673 & $18 \mathrm{~mol} \%$ & [16] \\
\hline & R723 & & & & & $\begin{array}{l}\text { Cu in LDH } \\
\text { (Co-ppt.), } \\
\text { oMSR }\end{array}$ & \\
\hline $\begin{array}{l}61.7 \% \\
\mathrm{Cu} / \mathrm{ZnO} / \mathrm{Al}_{2} \mathrm{O}_{3}\end{array}$ & R523 & 84.4 & $0.11^{\mathrm{c}}$ & 1.4 & 523 & $\begin{array}{l}\text { (commer- } \\
\text { cial) }\end{array}$ & [17] \\
\hline $32.3 \%$ & C723 & 71.7 & $0.22^{\mathrm{c}}$ & 8.7 & 503 & (Co-ppt.), & [18] \\
\hline $\mathrm{Cu} / \mathrm{ZnO} / \mathrm{ZrO}_{2}$ & R573 & & & & & oMSR & \\
\hline $35.5 \%$ & C723 & 66.8 & $0.23^{\mathrm{c}}$ & 8.2 & 503 & (Co-ppt.), & [18] \\
\hline $\mathrm{Cu} / \mathrm{ZnO} / \mathrm{CeO}_{2}$ & R523 & & & & & & \\
\hline $8.5 \% \mathrm{Cu} / \mathrm{ZrO}_{2}$ & C773 & 92 & $0.2^{\mathrm{c}}$ & - & 523 & (Templ. & [19] \\
\hline & R523 & & & & & & \\
\hline $16 \% \mathrm{Cu} / \mathrm{ZrO}_{2}$ & C673 & 57 & $0.02^{\mathrm{c}}$ & - & 523 & & [20] \\
\hline & R523 & & & & & method) & \\
\hline $3.9 \% \mathrm{Cu} / \mathrm{CeO}_{2}$ & $\mathrm{C} 723$ & 90.7 & $2.3^{\mathrm{d}}$ & 10.9 & 533 & (Co-ppt.) & [21] \\
\hline & R673 & & & & & & \\
\hline $3.9 \% \mathrm{Cu} / \mathrm{ZnO}$ & $\mathrm{C} 723$ & 66.8 & $0.9^{\mathrm{d}}$ & 8.0 & 533 & (Co-ppt). & [21] \\
\hline & R673 & & & & & & \\
\hline $3.9 \% \mathrm{Cu} / \mathrm{Al}_{2} \mathrm{O}_{3}$ & C723 & 21.5 & $0.4^{\mathrm{d}}$ & 2.6 & 533 & (Co-ppt.) & [21] \\
\hline & R673 & & & & & & \\
\hline QC- $-\mathrm{Al}_{63} \mathrm{Cu}_{25} \mathrm{Fe}_{12}{ }^{\mathrm{f}}$ & R523 & - & - & 14.1 & 573 & $\mathrm{~L}: \mathrm{NaOH}$ & [22] \\
\hline $\mathrm{CuAl}_{2}$ & & - & - & 3.81 & 513 & L:NaOH/ & [23] \\
\hline
\end{tabular}


$\mathrm{Na}_{2} \mathrm{CrO}_{4}$

\begin{tabular}{|c|c|c|c|c|c|c|c|}
\hline $\mathrm{Ni}_{3} \mathrm{Al}$ & R523 & 10 & $6^{\mathrm{e}}$ & $56^{\mathrm{g}}$ & 793 & & {$[24]$} \\
\hline \multirow[t]{2}{*}{$\mathrm{A}-\left(\mathrm{Cu}_{50} \mathrm{Zr}_{50}\right)_{90} \mathrm{Au}_{10}{ }^{\mathrm{f}}$} & C550 & 80 & $100^{\mathrm{e}}$ & 14.0 & 523 & & {$[25]$} \\
\hline & R573 & & & & & & \\
\hline \multirow[t]{2}{*}{$10 \% \mathrm{Pd} / \mathrm{SiO}_{2}$} & $\mathrm{C} 773$ & 15.7 & $0^{\mathrm{e}}$ & 2.82 & 493 & & {$[26]$} \\
\hline & $\mathrm{R} 773$ & & & & & & \\
\hline \multirow[t]{2}{*}{$10 \% \mathrm{Pd} / \mathrm{Al}_{2} \mathrm{O}_{3}$} & $\mathrm{C} 773$ & 67.4 & $0^{\mathrm{e}}$ & 12.14 & 493 & & {$[26]$} \\
\hline & $\mathrm{R} 773$ & & & & & & \\
\hline \multirow[t]{2}{*}{$10 \% \mathrm{Pd} / \mathrm{ZnO}$} & $\mathrm{C} 773$ & 55 & $99.8^{\mathrm{e}}$ & 9.80 & 493 & & {$[26]$} \\
\hline & $\mathrm{R} 773$ & & & & & & \\
\hline \multirow[t]{2}{*}{$10 \% \mathrm{Pt} / \mathrm{SiO}_{2}$} & $\mathrm{C} 773$ & 25.6 & $0.3^{\mathrm{e}}$ & $4.61^{\mathrm{h}}$ & $493^{\mathrm{h}}$ & & {$[27]$} \\
\hline & $\mathrm{R} 773$ & & & & & & \\
\hline \multirow[t]{2}{*}{$10 \% \mathrm{Pt} / \mathrm{ZnO}$} & $\mathrm{C} 773$ & 27.6 & $95.4^{\mathrm{e}}$ & 4.96 & 493 & & {$[26]$} \\
\hline & $\mathrm{R} 773$ & & & & & & \\
\hline $2 \% \mathrm{Pt}-\mathrm{Zn} / \mathrm{C}$ & $\mathrm{R} 873$ & 100 & $83^{\mathrm{e}}$ & 1.12 & 553 & $\mathrm{Zn} / \mathrm{Pt}=5.0$ & {$[27]$} \\
\hline $2 \% \mathrm{Pt} / \mathrm{C}$ & $\mathrm{R} 873$ & 76 & $48^{\mathrm{e}}$ & 0.84 & 553 & & {$[27]$} \\
\hline $10 \% \mathrm{Pt} / \mathrm{In}_{2} \mathrm{O}_{3}$ & $\mathrm{C} 773$ & 30.6 & $98.3^{\mathrm{e}}$ & 5.51 & 493 & & {$[28]$} \\
\hline \multirow{3}{*}{$10 \% \mathrm{Pt} / \mathrm{Ga}_{2} \mathrm{O}_{3}$} & $\mathrm{R} 773$ & & & & & & \\
\hline & $\mathrm{C} 773$ & 5.4 & $75.5^{\mathrm{e}}$ & 0.97 & 493 & & [28] \\
\hline & $\mathrm{R} 773$ & & & & & & \\
\hline $10 \% \mathrm{Pd} / \mathrm{Ga}_{2} \mathrm{O}_{3}$ & $\mathrm{C} 773$ & 21.2 & $94.6^{\mathrm{e}}$ & 3.82 & 493 & & {$[26]$} \\
\hline \multirow{3}{*}{$10 \% \mathrm{Pd} / \mathrm{In}_{2} \mathrm{O}_{3}$} & $\mathrm{R} 773$ & & & & & & \\
\hline & C773 & 28.3 & $95.5^{\circ}$ & 5.10 & 493 & & [26] \\
\hline & $\mathrm{R} 773$ & & & & & & \\
\hline $15 \% \mathrm{Pd}-\mathrm{In} / \mathrm{Al}_{2} \mathrm{O}_{3}$ & C673 & 91 & $98.7^{\mathrm{e}}$ & 68.25 & 698 & $\mathrm{In} / \mathrm{Pd}=2$ & {$[29]$} \\
\hline \multirow[t]{2}{*}{$8.9 \% \mathrm{Pd}-\mathrm{Zn} / \mathrm{Al}_{2} \mathrm{O}_{3}$} & $\mathrm{C} 623$ & 46.5 & $99.4^{\mathrm{e}}$ & 4.1 & 493 & $\mathrm{Zn} / \mathrm{Pd}=$ & {$[30]$} \\
\hline & R673 & & & & & 2.6 & \\
\hline \multirow[t]{2}{*}{$8.6 \% \mathrm{Pd} / \mathrm{ZnO}$} & $\mathrm{C} 623$ & 14.3 & $99.2^{\mathrm{e}}$ & 1.6 & 493 & & {$[30]$} \\
\hline & R673 & & & & & & \\
\hline \multirow[t]{2}{*}{$10 \% \mathrm{Ni} / \mathrm{ZnO}$} & $\mathrm{C} 773$ & 15.7 & $4.7^{\mathrm{e}}$ & $2.83^{\mathrm{h}}$ & $493^{\mathrm{h}}$ & & {$[27]$} \\
\hline & $\mathrm{R} 773$ & & & & & & \\
\hline \multirow[t]{2}{*}{$10 \% \mathrm{Ni} / \mathrm{SiO}_{2}$} & $\mathrm{C} 773$ & 7.3 & $1.1^{\mathrm{e}}$ & $1.31^{\mathrm{c}}$ & $493^{c}$ & & {$[27]$} \\
\hline & $\mathrm{R} 773$ & & & & & & \\
\hline \multirow{2}{*}{$10 \% \mathrm{Co} / \mathrm{ZnO}$} & $\mathrm{C} 773$ & 20.3 & $8.9^{\circ}$ & $3.65^{11}$ & $493^{\mathrm{h}}$ & & {$[27]$} \\
\hline & $\mathrm{R} 773$ & & & & & & \\
\hline Pd black & R513 & $7^{1}$ & $2^{\mathrm{e}}$ & 13.3 & 533 & & {$[31]$} \\
\hline $\mathrm{ZnPd}$ & R513 & $7^{\mathrm{i}}$ & $100^{\mathrm{e}}$ & 2.6 & 533 & & {$[31]$} \\
\hline PtZn & R513 & $7^{\mathrm{i}}$ & $50^{\mathrm{e}}$ & 2.6 & 533 & & {$[31]$} \\
\hline $\mathrm{PdCd}$ & R513 & $7^{\mathrm{i}}$ & $100^{\mathrm{e}}$ & 2.6 & 533 & & {$[31]$} \\
\hline $\mathrm{NiZn}$ & R513 & $7^{i}$ & $15^{\mathrm{e}}$ & 2.6 & 533 & & {$[31]$} \\
\hline
\end{tabular}


${ }^{\mathrm{b}}$ Methods of preparation $(\mathrm{Co}-\mathrm{ppt} .=$ co-precipitation, templ. method $=$ template method, $\mathrm{ME}$ method $=$ microemulsion method, $\mathrm{LDH}=$ layered double hydroxide, $\mathrm{L}=$ leaching agent $)$, oMSR = oxidative MSR

${ }^{c}$ given as $\mathrm{CO}$ concentration in the product gas

d given as selectivity towards $\mathrm{CO}$

e given as selectivity towards $\mathrm{CO}_{2}$

${ }^{\mathrm{f}} \mathrm{QC}$ :quasicrystalline, A: amorphous

$\mathrm{g}$ in $\mathrm{Lh}^{-1} \mathrm{~m}^{-2}$

${ }^{\mathrm{h}}$ derived from comparison to data from [26]

i $7 \%$ to $10 \%$ given

\section{Cu-based Catalysts for Methanol Steam reform- ing}

$\mathrm{Cu}$-based catalysts are widely used in $\mathrm{C} 1$ chemistry. This is mostly due to the commercial interest in the most common industrial methanol synthesis catalyst, a complex $\mathrm{Cu} / \mathrm{ZnO} / \mathrm{Al}_{2} \mathrm{O}_{3}$ bulk catalyst, which is also active in MSR and fulfills many of the requirements mentioned above, such as high activity at low temperature, relatively low CO levels, and feasible and scalable - though complex - preparation at moderate costs. Commercial ternary $\mathrm{Cu} / \mathrm{ZnO} / \mathrm{Al}_{2} \mathrm{O}_{3}$ catalysts or the unpromoted binary $\mathrm{Cu} / \mathrm{ZnO}$ model system were thus employed in many studies of MSR and this material will be discussed in detail below. While preparation and composition of the industrial catalyst $\mathrm{Cu} / \mathrm{ZnO} / \mathrm{Al}_{2} \mathrm{O}_{3}$ can be regarded as already highly optimized for application under methanol synthesis conditions, modifications of the $\mathrm{Cu} / \mathrm{ZnO} / \mathrm{X}$ system turned out to improve the properties of $\mathrm{Cu}$-based catalysts for use in MSR. In particular, choosing another second oxide phase $\mathrm{X}$ or employing new catalyst precursors like layered double hydroxides, or even changing to $\mathrm{ZnO}$-free samples and using zirconia or ceria for preparation of $\mathrm{Cu}$-based catalysts 
was reported to lead to interesting MSR performance. The state of the active $\mathrm{Cu}$ surface under reaction conditions and the nature of the active sites are still debated in literature and will be discussed in this section.

Several studies are available addressing the mechanism and kinetics of the MSR reaction over $\mathrm{Cu}$ based catalysts [32-38]. There seems to be agreement nowadays that $\mathrm{CO}_{2}$ is a direct product of the MSR reaction and not of a sequence of MD and WGS reactions. The main source of $\mathrm{CO}$ is the rWGS reaction taking place as a secondary reaction after MSR. Frank et al. [38] presented a comprehensive microkinetic analysis of the MSR reaction based on the work of Peppley et al. [34]. They investigated several $\mathrm{Cu}$-based catalysts with various oxide components showing considerably different activities. Similar activation energies support the idea that the surface chemistry is independent of the oxide material (with the exception of $\mathrm{Cu} / \mathrm{Cr}_{2} \mathrm{O}_{3} / \mathrm{Fe}_{2} \mathrm{O}_{3}$, which behaved differently). Dehydrogenation of methoxy groups is the rate limiting step and by means of DRIFTS experiments methoxy and formate species were found as the dominating species at the surface. Two distinct kinds of active sites were considered, $\mathrm{S}_{\mathrm{A}}$ for the adsorption and desorption of oxygenates and $\mathrm{S}_{\mathrm{B}}$ for hydrogen (Fig. 1) and two reaction pathways of the methoxy intermediate are discussed via dioxomethylene, the intermediate of the reverse methanol synthesis reaction, or methyl formate. On basis of the kinetic data it was not possible to decide which route was dominant. 


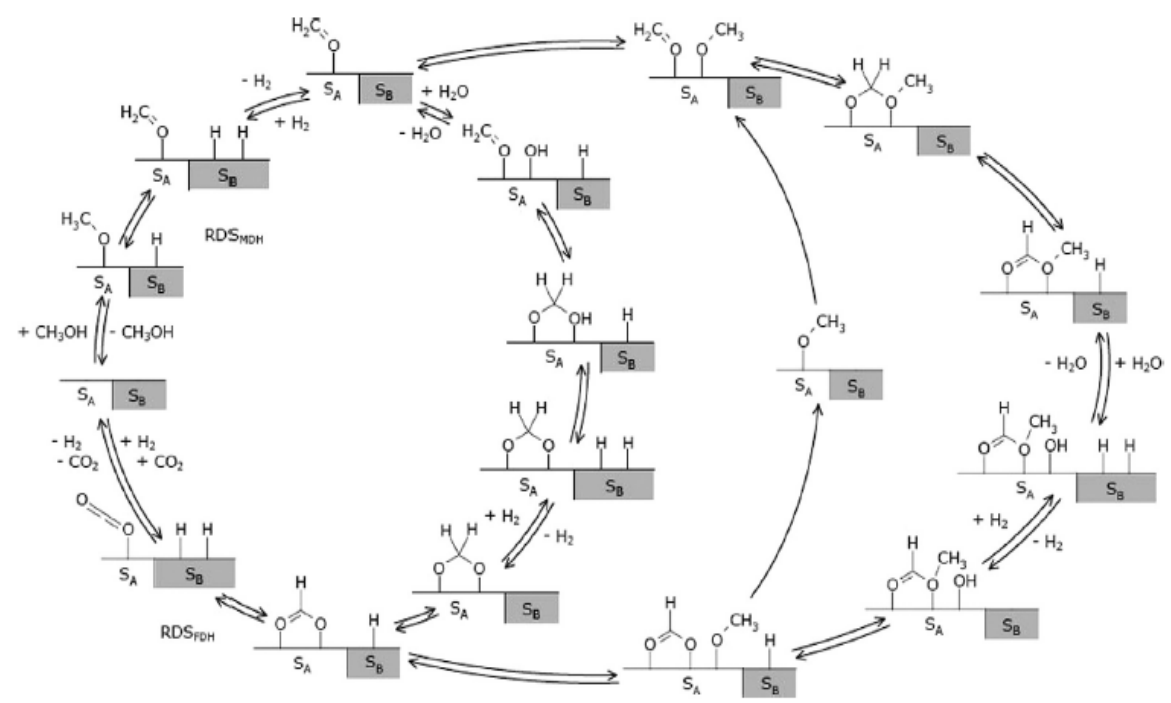

Fig. 1: Catalysis cycle for MSR over Cu-based catalysts based on the work in refs [32-34] including two different kinds of reactive sites $\mathrm{S}_{\mathrm{A}}$ and $\mathrm{S}_{\mathrm{B}}$. Reprinted from ref [38] with permission from Elsevier.

\section{General aspects of $\mathrm{Cu} / \mathrm{ZnO}$-based catalysts}

Commercial $\mathrm{Cu} / \mathrm{ZnO} / \mathrm{Al}_{2} \mathrm{O}_{3}$ methanol synthesis catalysts are often mistaken as supported systems, but neither $\mathrm{ZnO}$ nor $\mathrm{Al}_{2} \mathrm{O}_{3}$ represent classical extended oxidic supports. This is obvious, when considering the typical composition of modern $\mathrm{Cu} / \mathrm{ZnO} /\left(\mathrm{Al}_{2} \mathrm{O}_{3}\right)$ catalysts, which is characterized by a molar $\mathrm{Cu}: \mathrm{Zn}$ ratio close to 70:30, while the amount of $\mathrm{Al}_{2} \mathrm{O}_{3}$ typically is significantly lower than that of $\mathrm{ZnO}$. This $\mathrm{Cu}$-rich composition manifests itself in a peculiar microstructure of the industrial $\mathrm{Cu} / \mathrm{ZnO} / \mathrm{Al}_{2} \mathrm{O}_{3}$ catalyst (Fig. 2) [39], which is composed of spherical $\mathrm{Cu}$ nanoparticles of a size $<10 \mathrm{~nm}$ and often even smaller $\mathrm{ZnO}$ nanoparticles arranged in an alternating fashion. Thus, porous aggregates are formed (Fig. 2d) in which the oxide particles act as spacers between $\mathrm{Cu}$ particles (Fig. 2e). The 
presence of inter-particle pores as seen in the HRTEM image allows some access to the "inner surface" of larger $\mathrm{Cu} / \mathrm{ZnO}$ aggregates. This unique microstructure, represented in Figure $2 b$, can be described as an intermediate stage between a supported catalyst, schematically drawn in Figure 2a, and a bulk metallic sponge or skeletal Raney-type catalyst, represented in Figure 2c.

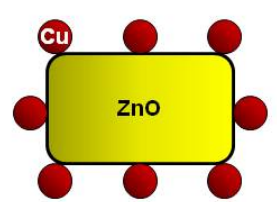

a) Supported catalyst

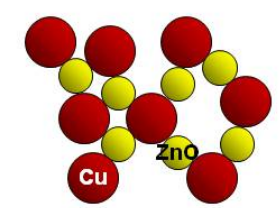

b) Porous bulk catalyst

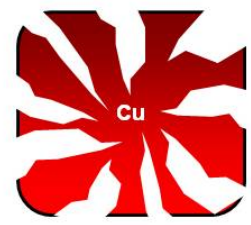

c) Skeletal catalyst

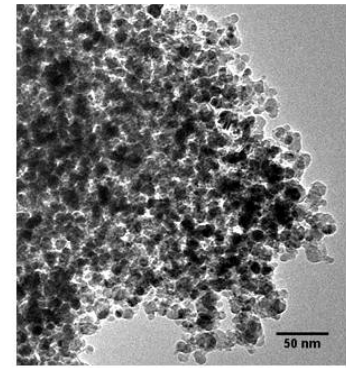

d) $\mathrm{Cu} / \mathrm{ZnO}$ aggregates

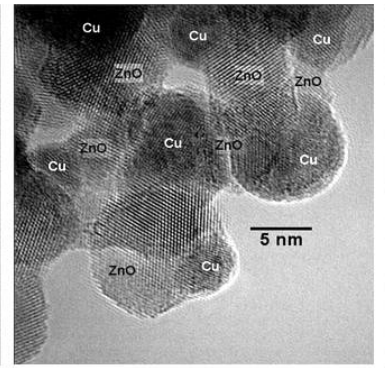

e) $\mathrm{Cu} / \mathrm{ZnO}$ microstructure

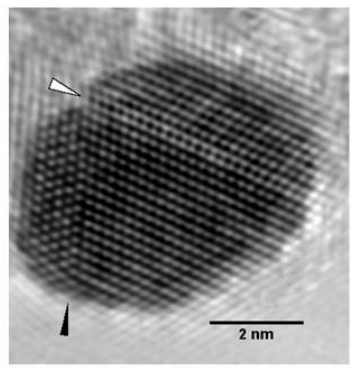

f) Faulted Cu nanoparticle

Fig. 2: Schemes of different catalyst microstructures (a-c) and transmission electron micrographs of a $\mathrm{Cu} / \mathrm{ZnO} /\left(\mathrm{Al}_{2} \mathrm{O}_{3}\right)$ catalyst (d-e). In the high resolution image (f) planar defects of the $\mathrm{Cu}$ nanoparticles like twin boundaries (black arrow) and stacking faults (white arrow) can be seen.

It is this unique microstructure, which enables a reasonably high dispersion of $\mathrm{Cu}$ and exposure of many $\mathrm{Cu}-\mathrm{ZnO}$ interfaces at a high total $\mathrm{Cu}$ content. The specific $\mathrm{Cu}$ surface area $\left(\mathrm{SA}_{\mathrm{Cu}}\right)$ of methanol catalysts can be determined by reactive $\mathrm{N}_{2} \mathrm{O}$ titration [40], which causes surface oxidation of the $\mathrm{Cu}$ particles and allows estimation of 
$\mathrm{SA}_{\mathrm{Cu}}$ from the amount of evolved $\mathrm{N}_{2}$, as $\mathrm{N}_{2} \mathrm{O}$ is decomposed at the metallic $\mathrm{Cu}$ surface, or from the $\mathrm{H}_{2}$ consumption upon re-reduction. Assuming formation of an oxygen monolayer, a surface stochiometry corresponding to $\mathrm{Cu}_{2} \mathrm{O}$ and an abundance of $1.47 \times 10^{19}$ oxygen atoms $/ \mathrm{m}^{2}, \mathrm{SA}_{\mathrm{Cu}}$ can be calculated in $\mathrm{m}^{2} \mathrm{~g}^{-1}$. This method has to be applied carefully, as for instance too high temperatures may cause a significant extent of bulk oxidation, which leads to an overestimation of $\mathrm{SA}_{\mathrm{Cu}}[41,42]$. Also reaction of oxygen vacancies of the oxide components with $\mathrm{N}_{2} \mathrm{O}$ or modified reactivity of a defective $\mathrm{Cu}$ surface towards $\mathrm{N}_{2} \mathrm{O}$ may be a source of error. $\mathrm{SA}_{\mathrm{Cu}}$ of the state-of-theart methanol synthesis catalyst measured by this method amounts to $25-35 \mathrm{~m}^{2} \mathrm{~g}^{-1}$. If reliable data of the average $\mathrm{Cu}$ particle size are available, e.g. by sufficient TEM observations [39], the degree of oxide coverage of the $\mathrm{Cu}$ particles, i.e. the average ratio of interface to surface area, can be calculated. For industrial $\mathrm{Cu} / \mathrm{ZnO} / \mathrm{Al}_{2} \mathrm{O}_{3}$ catalysts, this value is around 35\% [43]. The high MSR activity of this type of $\mathrm{Cu} / \mathrm{ZnO} /\left(\mathrm{Al}_{2} \mathrm{O}_{3}\right)$ catalysts at relatively low temperatures can most likely be explained with the large $\mathrm{SA}_{\mathrm{Cu}}$ due to this favorable microstructure and to the proper balance of $\mathrm{Cu}$ dispersion and loading. Clearly, one role of $\mathrm{ZnO}$ is to act as spacer and stabilizer avoiding direct contact of the $\mathrm{Cu}$ particles and preventing them from sintering [44]. In addition to this geometrical function, a so-called $\mathrm{Cu}-\mathrm{ZnO}$ synergy is described in literature for the methanol synthesis reaction [45]. The nature of this synergy is debated and several models have been proposed. Strong metal-oxide-interactions (SMSI) between $\mathrm{Cu}$ and $\mathrm{ZnO}$ were observed at highly reducing conditions [46] and it 
was suggested that partially reduced $\mathrm{ZnO}_{\mathrm{x}}$ migrates onto the surface of the $\mathrm{Cu}$ particles under methanol synthesis conditions [47]. On a supported $\mathrm{Cu} / \mathrm{ZnO}$ model catalyst, reversible wetting/de-wetting was observed as the reduction potential of the gas phase was varied [48] which was not detected on $\mathrm{Cu} / \mathrm{SiO}_{2}$. While the role of surface decoration or morphology change for high performance catalysts under industrial methanol synthesis conditions is still unclear, a correlation of the concentration of planar defects in the $\mathrm{Cu}$ particles with the catalytic activity in methanol synthesis was observed in a series of industrial $\mathrm{Cu} / \mathrm{ZnO} / \mathrm{Al}_{2} \mathrm{O}_{3}$ catalysts by Kasatkin et al. [39]. Planar defects like stacking faults and twin boundaries can also be observed by HRTEM and are marked with arrows in Figure $2 \mathrm{f}$. The origin of strain and defects is thought to be the interface of the $\mathrm{Cu}$ particles with the $\mathrm{ZnO}$ phase.

It is generally agreed that the role of $\mathrm{ZnO}$ in $\mathrm{Cu}$-based methanol synthesis catalysts exceeds the function of a mere physical stabilizer and $\mathrm{ZnO}$ is a crucial component in high performance methanol synthesis catalysts. In light of the fact, that highly active $\mathrm{Cu}$-based MSR catalysts can also be prepared in absence of $\mathrm{ZnO}$ (e.g. as $\mathrm{Cu} / \mathrm{ZrO}_{2}$, see below), this type of $\mathrm{Cu}-\mathrm{ZnO}$ synergy does not seem to be an as critical factor in case of MSR compared to methanol synthesis or it is not as strictly limited to $\mathrm{ZnO}$.

On the other hand, there are many similarities of methanol synthesis and MSR [35]. This is often accounted for by the concept of microscopic reversibility, as MSR formally is the reverse reaction of methanol synthesis. It has to be considered, however, that the differ- 
ent reactant gas mixtures used for MSR and methanol synthesis will affect the surface state of the catalyst, which consequently will be different under highly reducing methanol synthesis conditions compared to the much less reducing MSR feed. Thus, unlike forward and backward reactions at equilibrium, methanol synthesis and MSR probably take place over practically different catalytic surfaces. This general limit of the application of the concept of microscopic reversibility has been pointed out by Spencer for WGS and rWGS [49] and is valid accordingly also for methanol synthesis and MSR [50]. One may conclude that an optimized methanol synthesis catalyst, for which the fine tuning of preparation and operation conditions is far more advanced, will also be active in MSR due to its generally large $\mathrm{SA}_{\mathrm{Cu}}$ and represents a powerful reference system, but it does not necessarily represent the optimal catalyst for this reaction [50]. Finding $\mathrm{Cu} / \mathrm{ZnO} / \mathrm{X}$ systems with a composition and microstructure optimized for the MSR reaction is thus the major current challenge in development of a MSR catalyst for energy applications.

\section{Drawbacks of $\mathrm{Cu} / \mathrm{ZnO}$-based catalysts}

The unique microstructure of modern $\mathrm{Cu} / \mathrm{ZnO} /\left(\mathrm{Al}_{2} \mathrm{O}_{3}\right)$ methanol synthesis catalysts described above is responsible for many advantages of $\mathrm{Cu}$-based catalysts and their application in MSR, such as high $\mathrm{SA}_{\mathrm{Cu}}$. However, a major drawback of $\mathrm{Cu}$-based catalysts is their lack in long-term stability.

A loss of $30-40 \%$ of the initial MSR activity was observed by Frank et al. [38] for a selection of $\mathrm{Cu}$-based catalysts in combination with 
different oxide components (Fig 3d). Deactivation proceeds fast during the first 100 hours on stream and tends to level off afterwards. Deactivation of $\mathrm{Cu} / \mathrm{ZnO} / \mathrm{Al}_{2} \mathrm{O}_{3}$ catalysts in MSR has been reviewed by Twigg and Spencer [50]. A major aspect is the loss of $\mathrm{SA}_{\mathrm{Cu}}$ due to $\mathrm{Cu}$ particle sintering. The melting point of elemental $\mathrm{Cu}$ is relatively low at $\mathrm{T}_{\mathrm{M}}=1336 \mathrm{~K}$ resulting in low Tamann and Hüttig temperatures of $0.5 \mathrm{~T}_{\mathrm{M}}$ and $0.3 \mathrm{~T}_{\mathrm{M}}$, respectively. The former refers to the approximated onset temperature of atom mobility leading to thermal sintering, while the latter is estimated to be the onset temperature of defect annealing. Compared to other metals, $\mathrm{Cu}$ is generally quite sensitive to sintering [51] and, as a rule of thumb, $\mathrm{Cu}-$ based catalysts should not be operated above ca. $600 \mathrm{~K}$ after activation. For the same reason, also the pre-treatment conditions of the catalysts have to be selected with care. Especially the exothermic reduction step during catalyst activation is crucial, as the heat of reduction may cause high local temperatures, thermal sintering and a loss of $\mathrm{SA}_{\mathrm{Cu}}$. In spent $\mathrm{Cu}$-rich commercial methanol synthesis catalysts intermediate stages of sintering by coalescence can be identified by HRTEM (Fig. 3a,b) [52]. Interestingly, the formation of fivefold cyclic twins originating from the contact area of two $\mathrm{Cu}$ particles is observed in these images. The evolution of the $\mathrm{Cu}$ particle size distributions (Fig. 3c), determined by evaluation of TEM micrographs of several thousand $\mathrm{Cu}$ particles, shows a clear widening and shift of the particle size distribution to larger particle diameters. 
a)

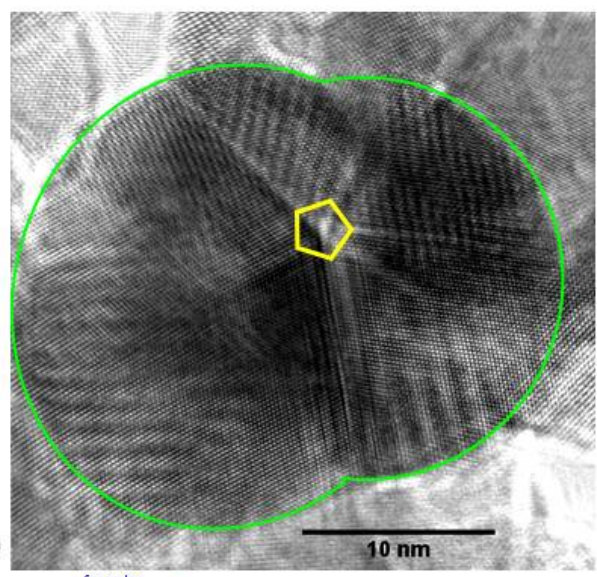

b)

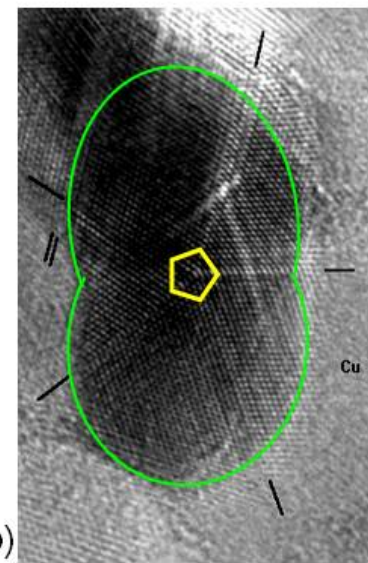

c)

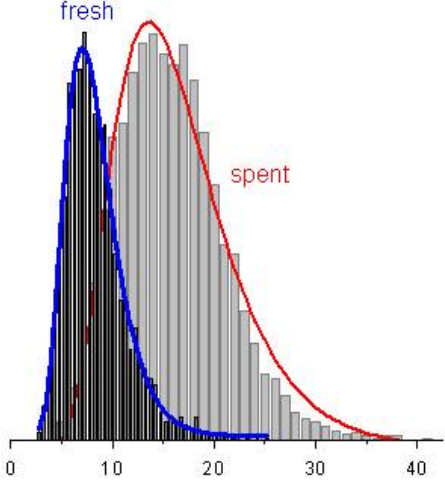

Cu particle diameter, $\mathrm{nm}$

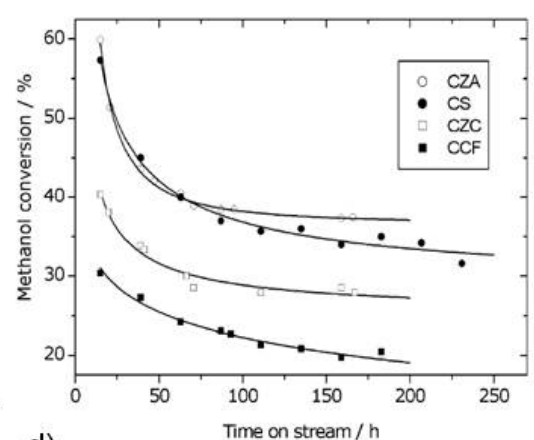

d)

Fig. 3: HRTEM images of $\mathrm{Cu} / \mathrm{ZnO} / \mathrm{Al}_{2} \mathrm{O}_{3}$ catalyst used in methanol synthesis $(\mathrm{a}, \mathrm{b})$; evolution of the particle size distribution during reaction (c); and loss in methanol conversion with time on stream for different $\mathrm{Cu}$-based catalysts during MSR at $493 \mathrm{~K}, 1$ bar, $\mathrm{MeOH}: \mathrm{H}_{2} \mathrm{O}=1: 1$ (d, CZA: $0.5 \mathrm{~g} \mathrm{Cu} / \mathrm{ZnO} / \mathrm{Al}_{2} \mathrm{O}_{3}, \mathrm{CS}: 2.0 \mathrm{~g} \mathrm{Cu} / \mathrm{SiO}_{2}, \mathrm{CZC}: 1.0 \mathrm{~g} \mathrm{Cu} / \mathrm{ZrO}_{2} / \mathrm{CeO}_{2}, \mathrm{CCF}: 2.5 \mathrm{~g} \mathrm{Cu} / \mathrm{Cr}_{2} \mathrm{O}_{3} / \mathrm{Fe}_{2} \mathrm{O}_{3}$, Reprinted from ref [38] with permission from Elsevier)

Rapid deactivation is not only caused by external heat input during reaction alone, also the operating atmosphere of the catalyst has to be considered. In methanol synthesis, which is operated at a similar temperature like $\mathrm{MSR}$, modern $\mathrm{Cu} / \mathrm{ZnO} / \mathrm{Al}_{2} \mathrm{O}_{3}$ catalysts can deliver stable performance over years on stream. The same catalyst may tend to deactivate more rapidly under MSR conditions suggesting a critical role of the gas phase composition, most probably of water in 
the feed, on the sintering behavior. Löffler et al. [53] investigated the stability of several commercial WGS catalysts in the MSR reaction and fitted their data using a sintering model. $\mathrm{Cu} / \mathrm{ZnO} / \mathrm{Al}_{2} \mathrm{O}_{3}$ formulations were found to be most active compared to other catalyst compositions, but were also most prone to deactivation by sintering. In their analysis of catalyst deactivation of a commercial $\mathrm{Cu} / \mathrm{ZnO} / \mathrm{Al}_{2} \mathrm{O}_{3}$ catalyst during MSR, Thurgood et al. [54] revealed that in addition to the loss of surface area, also the site concentration at the catalyst's surface declined with time on stream.

The sensitivity of a given $\mathrm{Cu} / \mathrm{ZnO} / \mathrm{X}$ catalyst towards sintering under MSR conditions is determined by three main aspects: Composition $(\mathrm{Cu}: \mathrm{Zn}$ ratio), nature of promoting oxide $\mathrm{X}$, and catalyst microstructure. Obviously, a high $\mathrm{Cu}: \mathrm{Zn}$ ratio will lower the distance between neighboring $\mathrm{Cu}$ particles and favor formation of direct contacts leading to sintering by particle coalescence. Lowering the $\mathrm{Cu}$ loading increases the stabilizer-to-metal ratio, and is thus expected to contribute to the stabilization of $\mathrm{Cu}$ particles. It is, however, usually not desired to significantly decrease the amount of active metal in a $\mathrm{Cu} / \mathrm{ZnO}$ catalyst. In particular, it is noted that for preparation of the porous $\mathrm{Cu}-\mathrm{ZnO}$ arrangement (Fig. 2) the $\mathrm{Cu}: \mathrm{Zn}$ ratio is a crucial parameter, which has a clear optimum depending on the solid state chemistry of the hydroxycarbonate precursor phase and cannot be varied freely without sacrificing $\mathrm{SA}_{\mathrm{Cu}}$ and, thus, activity (see below).

It seems much more promising to try to stabilize a $\mathrm{Cu} / \mathrm{ZnO}$ catalyst at a given (optimized) $\mathrm{Cu}: \mathrm{Zn}$ ratio by adding a second oxidic species 
$\mathrm{X}$ and thus modify the $\mathrm{Cu}-\mathrm{ZnO}$ interactions. In case of the methanol synthesis catalyst, these interactions seem to be significantly strengthened by addition of small amounts of $\mathrm{Al}_{2} \mathrm{O}_{3}$ [50]. Ternary $\mathrm{Cu} / \mathrm{ZnO} / \mathrm{Al}_{2} \mathrm{O}_{3}$ catalysts are significantly more stable towards thermal sintering and consequently show a considerably longer lifetime in methanol synthesis than binary $\mathrm{Cu} / \mathrm{ZnO}$ systems. In MSR also the hydrothermal stability of the oxide phase and its contact to the $\mathrm{Cu}$ particles has to be considered. Looking at Figure 2e it is obvious that not only thermal sintering induced by mobility of $\mathrm{Cu}$, but also segregation or re-crystallization of the $\mathrm{ZnO}$ component (e.g induced by steam) will have the same detrimental effect on the porous $\mathrm{Cu} / \mathrm{ZnO}$ arrangement and cause a loss of $\mathrm{SA}_{\mathrm{Cu}}$. Other $\mathrm{ZnO} / \mathrm{X}$ combinations than $\mathrm{ZnO} / \mathrm{Al}_{2} \mathrm{O}_{3}$, especially $\mathrm{ZnO} / \mathrm{ZrO}_{2}$ (see below) are promising candidates for preparation of improved $\mathrm{Cu}$-based MSR catalysts.

The third important consideration concerns the microstructure of the catalyst and is closely related to the $\mathrm{Cu}: \mathrm{Zn}$ ratio and to the stabilizing interactions between $\mathrm{Cu}$ metal and the oxide. Modern $\mathrm{Cu} / \mathrm{ZnO} / \mathrm{Al}_{2} \mathrm{O}_{3}$ catalysts exhibit a unique and apparently fragile microstructure. The nano-scaled arrangement of metallic $\mathrm{Cu}$ and oxidic spacer particles seen in Figure 2 is metastable and an irreversible gradual breakdown of the porous aggregates can be expected if the sample is submitted to thermal stress as the system lowers its free surface energy. Highly active $\mathrm{Cu} / \mathrm{ZnO} / \mathrm{Al}_{2} \mathrm{O}_{3}$ is pyrophoric and may even deactivate upon contact to air as the heat of oxidation of the highly reactive $\mathrm{Cu}$ nanoparticles is sufficient to cause sintering. A microstructure exhibiting larger and more stable $\mathrm{Cu}-\mathrm{ZnO}$ interfaces 
may thus be desirable in order to stabilize the $\mathrm{Cu}$ particles. It is noted that the catalyst's microstructure heavily depends on its preparation history [17]. For example, at a given industrially relevant composition $(\mathrm{Cu}: \mathrm{Zn}: \mathrm{Al}=60: 25: 15)$ the interface-to-surface ratio can be significantly increased to $50 \%$ for a $\mathrm{Cu} / \mathrm{ZnO} / \mathrm{Al}_{2} \mathrm{O}_{3}$ catalyst, if the precursor preparation is modified by going from a batch process including precipitate ageing to a continuous process suppressing the ageing period [43]. In this example, the $\mathrm{Cu}$ particles have a similar size like in a conventional $\mathrm{Cu} / \mathrm{ZnO} / \mathrm{Al}_{2} \mathrm{O}_{3}$ catalyst, but are more deeply embedded into an amorphous oxide matrix and modified $\mathrm{Cu}-$ oxide interactions can be expected (Fig. 4). Generally, a low value of the interface-to-surface ratio of the $\mathrm{Cu}$ particles enables a large $\mathrm{SA}_{\mathrm{Cu}}$, while a larger value leads to stronger embedment and different wetting behavior which may increase the stability of the catalyst towards thermal sintering. An intermediate value may represent a kind of compromise between both effects. 


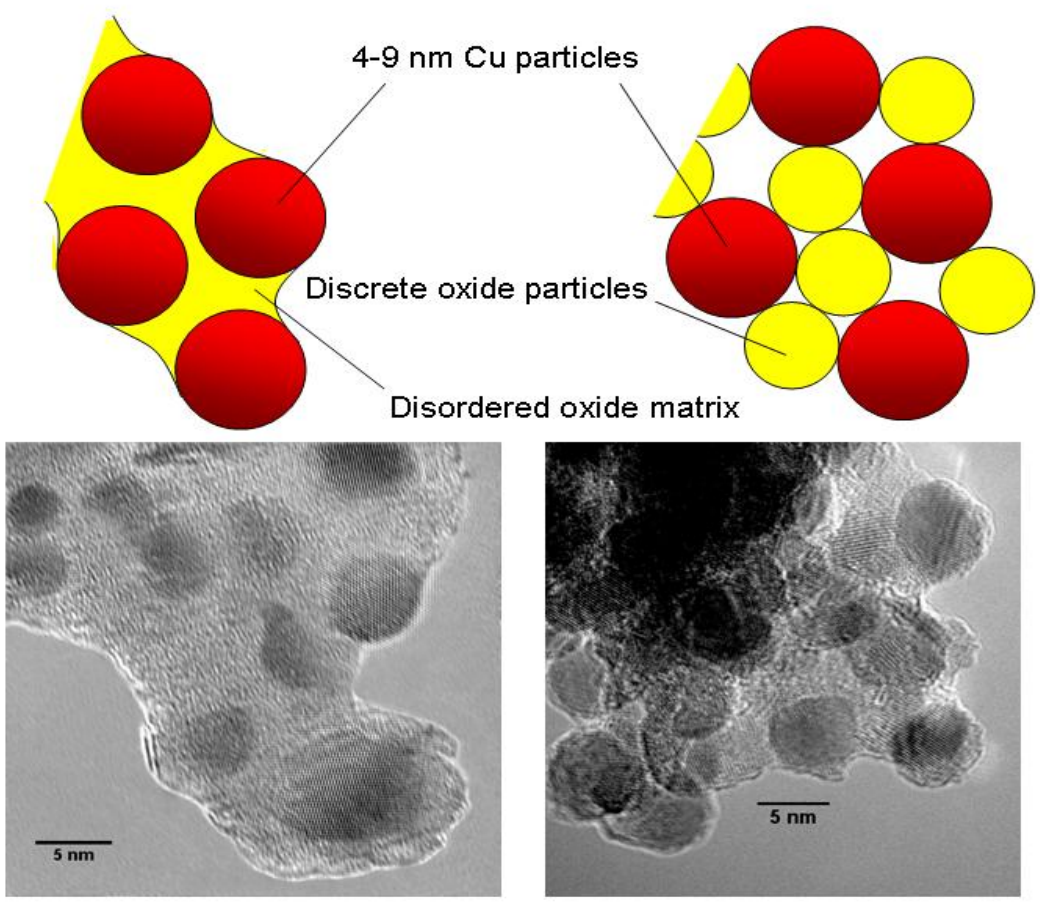

Fig. 4: Scheme and TEM micrographs of the microstructure of differently prepared $\mathrm{Cu} / \mathrm{ZnO} / \mathrm{Al}_{2} \mathrm{O}_{3}$ catalyst with the same composition and similar $\mathrm{Cu}$ particle sizes; adopted from ref [43].

Other sources of catalyst deactivation are catalyst poisons like sulfur or chlorine [50]. These contaminations do typically not originate from the methanol feed, but may be present in steam or air used for MSR or oxidative MSR. Sulfur acts as a site blocking poison for $\mathrm{Cu}$ and chlorine promotes sintering by formation of low-melting and mobile $\mathrm{Cu}$ and $\mathrm{Zn}$ chlorides. Agarwal et al. [55]. reported coke formation as another source of deactivation of $\mathrm{Cu} / \mathrm{ZnO} / \mathrm{Al}_{2} \mathrm{O}_{3}$ catalysts in MSR.

The other major problem of Cu-based MSR catalysts is the formation of still too much CO during MSR, typically in the low \%- 
range. Agrell et al. [56] reported that the problem of $\mathrm{CO}$ formation over $\mathrm{Cu} / \mathrm{ZnO} / \mathrm{Al}_{2} \mathrm{O}_{3}$ catalysts can be attenuated by increasing the steam-to-methanol ratio or by the addition of oxygen or air (oxidative MSR). $\mathrm{CO}$ is formed at high methanol conversions most likely by the rWGS reaction consecutively to MSR as a secondary product. Decreasing the contact time leads to lower CO selectivity. Lowering the reaction temperature is also helpful as it disfavors the rWGS equilibrium. Thus, probably the best way to make a Cu-based MSR catalyst less selective to $\mathrm{CO}$ would be to make it more active at lower temperatures.

\section{Preparation of $\mathrm{Cu} / \mathrm{ZnO}$-based catalysts}

The most studied member of the $\mathrm{Cu} / \mathrm{ZnO}$ catalysts family for $\mathrm{C} 1$ chemistry is the commercial methanol synthesis catalyst, which can be seen as a reference system for $\mathrm{Cu}$-based MSR catalysts (see above). It is prepared by co-precipitation, which is by far the most important method for synthesis of $\mathrm{Cu} / \mathrm{ZnO}$-based catalysts.

The industrially applied preparation of the low-temperature methanol synthesis catalyst was introduced by ICI company in 1966 and comprises co-precipitation and ageing of a mixed $\mathrm{Cu}, \mathrm{Zn},(\mathrm{Al})$ hydroxy-carbonate precursor material, thermal decomposition yielding an intimate mixture of the oxides and finally activation of the catalyst by reduction of the $\mathrm{Cu}$ component [57]. The synthesis parameters have been studied in many academic and industrial groups and a high degree of optimization could be achieved over the last decades by mostly empirical fine-tuning of the conditions. The delicate na- 
noparticulate and porous microstructure of the industrial methanol synthesis catalyst (see above) can only be obtained if the optimized parameters are strictly obeyed during synthesis. Especially the synthesis conditions during the early co-precipitation and ageing steps turned out to be crucial for the catalytic properties of the resulting methanol synthesis catalyst. This phenomenon, sometimes termed the "chemical memory" of the $\mathrm{Cu} / \mathrm{ZnO}$ system [58], indicates the critical role of the preparation history of this catalyst system $[17,59,60]$. As was already mentioned above and is obvious form Figure 2, the microstructural arrangement of $\mathrm{Cu}$ and $\mathrm{ZnO}$ in the final catalyst is metastable and tends to lower its free energy by sintering and segregation into macroscopic crystallites. Considering that the desired composite product is thus only kinetically stabilized and does not represent a deep minimum in the free energy landscape, it is not surprising that the precursor, i.e. the starting point of our path through the energy landscape during preparation, is of decisive importance for the exact position of our end point at which we wish to kinetically trap the system to obtain the arrangement like seen in Figure 2. Baltes et al. [59] elaborated a quantitative basis of the chemical memory in a systematic study and reported dramatic difference in $\mathrm{SA}_{\mathrm{Cu}}$ of $\mathrm{Cu} / \mathrm{ZnO} / \mathrm{Al}_{2} \mathrm{O}_{3}$ catalysts of the same composition as $\mathrm{pH}$ or temperature of the co-precipitation step was varied. If selfmade $\mathrm{Cu} / \mathrm{ZnO}$ catalysts are employed as reference systems for MSR studies, it is thus very important to carefully prepare the catalyst as it is much easier to synthesize a poor $\mathrm{Cu} / \mathrm{ZnO}$ catalyst than a good one, 
which could act as a conclusive reference for comparison with novel materials.

Preferred $\mathrm{Cu}: \mathrm{Zn}$ ratios for ternary $\mathrm{Cu}, \mathrm{Zn}, \mathrm{Al}$ and binary $\mathrm{Cu}, \mathrm{Zn}$ catalysts are near $70: 30$ [61] or 2:1 [62]. It was reported that the best catalysts can be obtained by constant $\mathrm{pH}$ co-precipitation with $\mathrm{Na}_{2} \mathrm{CO}_{3}$ solution at $\mathrm{pH} 6$ or 7 and at elevated temperatures around 333 - $343 \mathrm{~K}[59,63]$. Ageing of the initial precipitate is crucial $[62,64,65]$ and takes from around $30 \mathrm{~min}$ to several hours. Calcination is typically performed at relatively mild temperatures around $600-700 \mathrm{~K}$. No doubt, this multi-step preparation of $\mathrm{Cu} / \mathrm{ZnO}$ catalysts is complex, but some progress in understanding the chemical memory has been made recently and helps to rationalize the benefit of exactly this setting of parameters.

It is clear that the target microstructure shown in Figure 2 requires a homogeneous and maximized intermixing of the $\mathrm{Cu}$ and $\mathrm{Zn}$ species in order to stabilize the alternating arrangement of small $\mathrm{Cu}$ and $\mathrm{ZnO}$ nanoparticles. Thus, the main goal of the preparation is to carry over and maintain the perfectly homogeneous cation distribution in the mixed solution to a maximum extent via the precipitate to the final catalyst. The first step in this process is the solidification of the dissolved $\mathrm{Cu}$ and $\mathrm{Zn}$ cations by precipitation by elevation of $\mathrm{pH}$. Precipitation titration is an elegant way to study the cation hydrolysis of $\mathrm{Cu}^{2+}$ and $\mathrm{Zn}^{2+}$ under conditions relevant for catalyst preparation [66]. Such experimental results are shown in Figure 5a-c. 

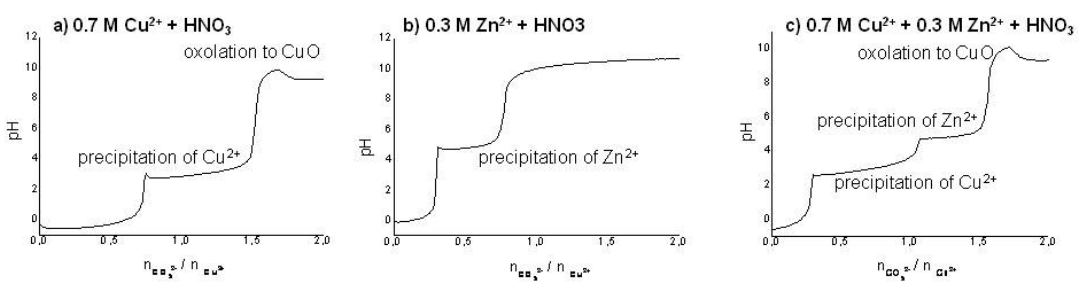

d) Constant $\mathrm{pH}$ co-precipitation and ageing $\left(\mathrm{pH} 7, \mathrm{~T}=65^{\circ} \mathrm{C}\right)$

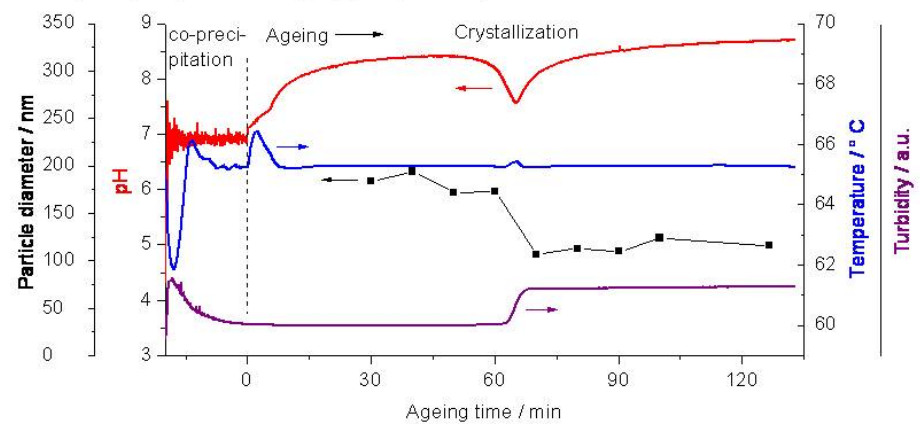

Fig. 5: Precipitation titration curves relevant for the co-precipitation of $\mathrm{Cu} / \mathrm{ZnO} / \mathrm{Al}_{2} \mathrm{O}_{3}$ catalyst precursors at $338 \mathrm{~K}$ using aq. $\mathrm{Na}_{2} \mathrm{CO}_{3}$ as precipitation agent (a-c, adopted from ref. [66]); preparation log of corresponding constant $\mathrm{pH}$ co-precipitation, adopted from ref. [67] (d).

It can be seen in Figure 5a that the hydrolysis of the pure $\mathrm{Cu}^{2+}$ solution is characterized by an underlying neutralization of the acidic starting solution with the basic precipitating agent. The S-shaped neutralization curve is interrupted by a precipitation plateau near $\mathrm{pH}$ 3 , where $\mathrm{Cu}^{2+}$ forms a precipitate. If we now look at the $\mathrm{Zn}^{2+}$ solution (Fig. 5b), a qualitatively similar picture emerges, but with the important difference that the $\mathrm{Zn}$-precipitate is formed at $\mathrm{pH} 5$ instead for $\mathrm{pH}$ 3. Such differences in hydrolysis behavior are of course not uncommon and are the basis for the traditional wet chemical ion separation techniques used for qualitative cation analysis. What is important, however, is that the precipitation titration curve of the binary system (Fig. 5c) is directly composed of those of the single sys- 
tems. This fact indicates that there is no formation of a mixed binary precipitate under these conditions, but that $\mathrm{Cu}^{2+}$ is first completely

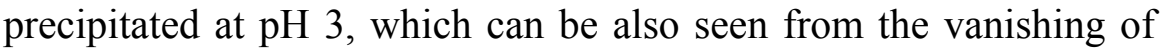
the blue color from the mother solution at $\mathrm{pH} 4$, while $\mathrm{Zn}^{2+}$ is precipitated "on top" later at $\mathrm{pH}$ 5. Clearly, such increasing $\mathrm{pH}$ processes cannot yield a well intermixed precipitate. The solution to this problem is the application of the constant $\mathrm{pH}$ co-precipitation technique $[68,69]$, meaning that the acidic metal solution and the precipitating agent are dosed simultaneously in a way that the average $\mathrm{pH}$ in the reaction vessel is maintained more or less constant. Using this mode of precipitation, it is possible to precipitate $\mathrm{Cu}$ and $\mathrm{Zn}$ very close in space and time as the curves shown in Figure 5 are passed through not for the whole batch at once, but for every single droplet that hits the receiver solution. Thus, the cation distribution in the precipitate obtained by constant $\mathrm{pH}$ co-precipitation is much more homogeneous [66].

Also the suitable $\mathrm{pH}$ for the precursor preparation can be deduced from the titration curves shown in Figure 5. It should not be lower than $\mathrm{pH} 5$ to guarantee complete precipitation of $\mathrm{Zn}^{2+}$ (and $\mathrm{Al}^{3+}$ ), which otherwise would remain at least partially in solution. On the other hand, the $\mathrm{pH}$ should stay below $\mathrm{pH}$ 9, because in a very basic solution de-mixing of the $\mathrm{Cu}, \mathrm{Zn}$ precipitate by oxolation of basic copper precipitates into stable tenorite, $\mathrm{CuO}$, occurs [66]. This oxolation can be seen as a dip in the titration curves at high $\mathrm{pH}$. Indeed, $\mathrm{CuZn}(\mathrm{Al})$ precursors are typically co-precipitated at neutral or even slightly acidic $\mathrm{pH}[59,62,63]$. It is noted that the position of the pre- 
cipitation plateaus are also a function of temperature [66]. An increase in temperature of co-precipitation leads to a shift of the titration curves to lower $\mathrm{pH}$ values confirming that the proper selection of $\mathrm{pH}$ and temperature is crucial to guarantee the rapid and complete solidification of all components. Thus, $\mathrm{pH} \mathrm{6-7} \mathrm{can} \mathrm{only} \mathrm{be} \mathrm{regarded}$ as optimal within a certain temperature window of 333-343 K $[59,66]$.

The initial $\mathrm{Cu}, \mathrm{Zn}$ precipitate obtained by constant $\mathrm{pH}$ coprecipitation undergoes important changes during stirring in the mother liquor. This ageing process is associated with crystallization, a change in color from blue to bluish green and a change in particle size and morphology (Fig. 6d) [67]. Ageing critically affects the micro-structural as well as the catalytic properties of the resulting $\mathrm{Cu} / \mathrm{ZnO}$ catalyst [70]. These changes occur rather step-like than gradually and are accompanied by a transient minimum in $\mathrm{pH}$. The phase composition of the ageing product is mostly determined by the $\mathrm{Cu}: \mathrm{Zn}$ ratio $[60,72]$, but also by the mode of precipitation [72], and the speed of addition of the precipitating agent [73]. Typical phases obtained when going from $\mathrm{Cu}$-rich to $\mathrm{Zn}$-rich compositions are malachite $\mathrm{Cu}_{2}(\mathrm{OH})_{2} \mathrm{CO}_{3}$, zincian malachite $(\mathrm{Cu}, \mathrm{Zn})_{2}(\mathrm{OH})_{2} \mathrm{CO}_{3}$ (sometimes called rosasite, see ref. [74]), aurichalcite $(\mathrm{Cu}, \mathrm{Zn})_{5}(\mathrm{OH})_{6}\left(\mathrm{CO}_{3}\right)_{2}$, hydrozincite $\mathrm{Zn}_{5}(\mathrm{OH})_{6}\left(\mathrm{CO}_{3}\right)_{2}$ and mixtures thereof. In ternary $\mathrm{Cu}, \mathrm{Zn}, \mathrm{Al}$ systems, also small amounts of layered double hydroxides may be observed. This precursor phase is covered in detail in the next section. Due to the homogeneity ranges of the mixed phases, a comprehensive characterization of the precursor is 
difficult. Zincian malachite was suggested to be the relevant precursor phase for industrial catalysts [62], which is also confirmed by the industrially applied $\mathrm{Cu}$-rich composition near $\mathrm{Cu}: \mathrm{Zn}=70: 30$, falling into the regime in which zincian malachite is the main product.

This view could be recently confirmed by a positive correlation of the $\mathrm{Zn}$-content in zincian malachite and the $\mathrm{SA}_{\mathrm{Cu}}$ of the resulting catalyst [67]. The $\mathrm{Zn}$ fraction can be estimated from the angular position of the characteristic $(20 \overline{1})$ XRD peak of the zincian malchite

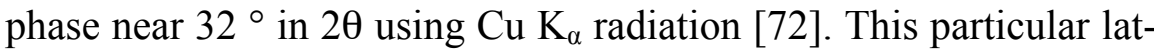
tice plane distance contracts as $\mathrm{Zn}^{2+}$ is incorporated into zincian malachite and the corresponding peak is shifted to higher angles. This is due to the average lowering of Jahn-Teller distortions of the $\mathrm{MO}_{6}$ building units in zincian malachite, whose elongated axes are aligned nearly perpendicular to this orientation. It is thus possible to measure the $\mathrm{Zn}$-content of this phase by conventional XRD despite the similar ionic radii and scattering factors of $\mathrm{Cu}$ and $\mathrm{Zn}$. It is noted that due to the anisotropic contraction of the monoclinic unit cell the other strong XRD peaks at lower angles, which are often employed for phase identification, are only hardly affected by $\mathrm{Cu}, \mathrm{Zn}$ substitution and do not give much diagnostic insight [74]. The decrease of the $(20 \overline{1})$ lattice plane distance upon incorporation of $\mathrm{Zn}$ into malachite was measured for catalyst precursor phases obtained after ageing of precipitates with different nominal $\mathrm{Cu}: \mathrm{Zn}$ ratio (Fig. 6) [67]. It can be seen that, under the conditions applied in this study, the limit of $\mathrm{Zn}$ incorporation is found near $28 \%$, i.e. at a composition close to 
$\left(\mathrm{Cu}_{0.72} \mathrm{Zn}_{0.28}\right)_{2}(\mathrm{OH})_{2} \mathrm{CO}_{3}$. For higher nominal $\mathrm{Zn}$ content no further shift of the $(20 \overline{1})$ reflection and crystallization of the Zn-richer aurichalcite phase as a side-product were observed. The largest $\mathrm{SA}_{\mathrm{Cu}}$ is observed for catalysts prepared from precursors near this critical composition (Fig. 6). This result strongly suggests that the desired porous microstructure of $\mathrm{Cu} / \mathrm{ZnO}$ catalysts (Fig. 2) is formed from highly substituted zincian malachite precursors, and that the applied $\mathrm{Cu}: \mathrm{Zn}$ ration near 70:30 is beneficial, because it lies near the incorporation limit of $\mathrm{Zn}$ in the malachite phase.

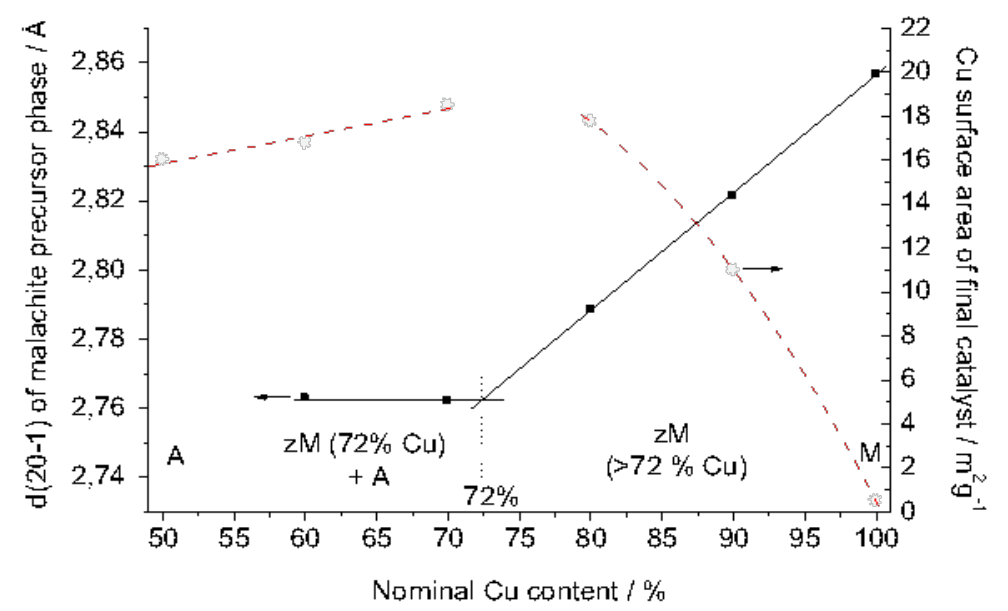

Fig. 6: Lattice contraction in the direction perpendicular to the (20 $\overline{1})$ planes of zincian malachite as a measure of $\mathrm{Zn}$ incorporation in the precursor phase and $\mathrm{SA}_{\mathrm{Cu}}$ of the final $\mathrm{Cu} / \mathrm{ZnO}$ catalyst as a function $\mathrm{Cu}$ content (Phase composition: M: malachite; zM: Zincian malachite; A: Aurichalcite); adopted from ref. [67].

This insight results in a simple geometrical model for the preparation of industrial $\mathrm{Cu} / \mathrm{ZnO}$ catalysts comprising subsequent mesoand nano-structuring of the material (Fig. 7) [67]. In a first micro- 
structure directing step (meso-structuring) the homogeneous $\mathrm{Cu}, \mathrm{Zn}$ precipitate obtained by constant-pH co-precipitation crystallizes in form of thin needles of zincian malachite. Thin and interwoven needles are desired, because the porosity of the final catalyst is already pre-determined at this step. In a second step, the individual needles are decomposed into $\mathrm{CuO}$ and $\mathrm{ZnO}$ and pseudo-morphs of the precursor needles can be still observed after mild calcinations [59]. Because both phases are only poorly miscible, a de-mixing cannot be avoided at this stage and nano-particles of the oxides, $\mathrm{CuO}$ and $\mathrm{ZnO}$, are formed. The effectiveness of this nano-structuring step depends critically on the $\mathrm{Zn}$-content of the precursor. The closer we approach a 1:1 ratio of $\mathrm{Cu}^{2+}$ and $\mathrm{Zn}^{2+}$ in the zincian malachite phase, the smaller the newly formed oxide particles will be and the higher is the dispersion of the $\mathrm{Cu}$ phase [67]. A 1:1 ratio of $\mathrm{Cu}$ and $\mathrm{Zn}$ in synthetic zincian malachite, however, seems to be inaccessible by conventional co-precipitation and ageing and due to solid state chemical constrains the limit is near 70:30 [74]. If we leave aside the synergetic effects of $\mathrm{Cu}$ and $\mathrm{ZnO}$ at this moment, the general benefit of using $\mathrm{Zn}^{2+}$ for the preparation of highly dispersed $\mathrm{Cu}$-based catalysts is a geometric effect due to the chemical similarity of $\mathrm{Cu}^{2+}$ and $\mathrm{Zn}^{2+}$ concerning cation charge and size in aqueous solutions and in the precursor state. This similarity enables a common solid state chemistry of $\mathrm{Cu}$ and $\mathrm{Zn}$ in one mixed precursor phase, may it be produced by co-precipitation or impregnation. Thus, highly intermixed precursors can be prepared easily in the $\mathrm{Cu}-\mathrm{Zn}$ system, leading to highly dispersed $\mathrm{Cu}$ and $\mathrm{ZnO}$ particles upon decomposition. 


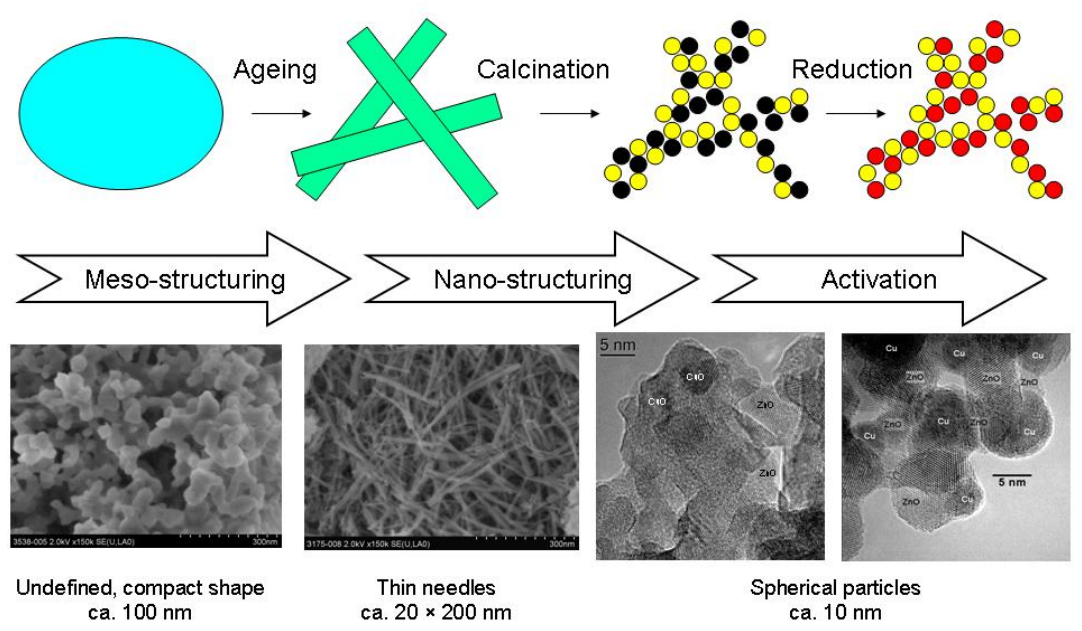

Fig. 7: Model for the chemical memory of $\mathrm{Cu} / \mathrm{ZnO} /\left(\mathrm{Al}_{2} \mathrm{O}_{3}\right)$ catalyst preparation comprising two microstructure directing steps.

This model of $\mathrm{Cu} / \mathrm{ZnO}$ preparation can explain the "chemical memory" of the industrial system, because the important material properties of the final catalyst like porosity and dispersion are already pre-determined by the properties of the precursor phase, like needle thickness and degree of $\mathrm{Zn}$ incorporation. It is also clear from this model that the synthesis conditions for industrial methanol synthesis catalysts were optimized in an unintended manner in order to improve the $\mathrm{Zn}$ incorporation into the zincian malachite precursor phase. This of course means that preparation of $\mathrm{Cu} / \mathrm{ZnO}$ catalyst from other precursor phases requires a new and adjusted set of preparation conditions. The 70:30 ratio represents the optimal compromise between loading and dispersion of $\mathrm{Cu}$ only for catalysts prepared from zincian malachite precursors and each other precursor or preparation method requires an own optimization of the $\mathrm{Cu}: \mathrm{Zn}$ ratio 
(and all other synthesis parameters). Catalysts of lower $\mathrm{Cu}: \mathrm{Zn}$ ratio than 70:30 are often used for MSR. This usually leads to formation of the aurichalcite precursor phase instead of zincian malachite during co-precipitation of the precursor $[58,71,75]$. Aurichalcite crystallizes in form of platelets rather than needles [64] and yields a $\mathrm{Cu} / \mathrm{ZnO}$ catalyst of different microstructure. $\mathrm{SA}_{\mathrm{Cu}}$ usually is lower $[61,67]$, but the embedment and $\mathrm{Cu}-\mathrm{ZnO}$ interactions may be more favorable for MSR. In contrast to zincian malachite, for aurichalcite, which usually does not require an extended ageing period to crystallize, a homogeneous co-precipitation method using urea decomposition has been reported to lead to highly active $\mathrm{Cu} / \mathrm{ZnO}$ MSR catalysts $[76,77]$. Promoting oxides $-\mathrm{Al}_{2} \mathrm{O}_{3}$ in case of the industrial catalyst - usually have a higher charge than $\mathrm{Cu}^{2+}$ or $\mathrm{Zn}^{2+}$ and in case of $\mathrm{M}^{3+}$ ions layered double hydroxides are very interesting for formation of $\mathrm{Cu} / \mathrm{ZnO} / \mathrm{Al}_{2} \mathrm{O}_{3}$ catalysts from a single precursor phase. Also for academic purposes it is generally desirable to prepare a $\mathrm{Cu} / \mathrm{ZnO}$-based catalyst from single-phase hydroxy-carbonate precursor to obtain a homogenous microstructure, which enables drawing reliable conclusions regarding the intrinsic activity of differently prepared $\mathrm{Cu}$ phases.

It is noted that $\mathrm{Cu} / \mathrm{ZnO} /\left(\mathrm{Al}_{2} \mathrm{O}_{3}\right)$ catalysts active in MSR can also be prepared from other precursors than hydroxy-carbonates, like mixed oxalates, [78] or following other recipes than co-precipitation, like reactive grinding [79] or CVD [80]. All these approaches will lead to different $\mathrm{Cu} / \mathrm{ZnO} /\left(\mathrm{Al}_{2} \mathrm{O}_{3}\right)$ catalytic materials, which have to proof their performance in comparison with the high-SA $\mathrm{Cu}_{\mathrm{Cu}}$ industrial refer- 
ence catalysts. It is crucial to combine such comparative catalytic studies with comprehensive material characterization to establish structure-performance relationships and to learn about possible routes to further optimize the $\mathrm{Cu} / \mathrm{ZnO} /\left(\mathrm{Al}_{2} \mathrm{O}_{3}\right)$ system for application in MSR.

\section{Ternary $\mathrm{Cu} / \mathrm{ZnO} / \mathrm{X}$ catalysts $\left(\mathrm{X}=\mathrm{Al}_{2} \mathrm{O}_{3}, \mathrm{ZrO}_{2}\right)$}

In contrast to the widely studied and debated role of $\mathrm{ZnO}$, which can be separated into a geometric (spacer function) and an electronic (synergetic $\mathrm{Cu}-\mathrm{ZnO}$ interactions) contribution (see above), only very little is known about the origin of the beneficial role of $\mathrm{Al}_{2} \mathrm{O}_{3}$. Its presence leads to an improved thermal stability and higher intrinsic activity in methanol synthesis $[50,81]$ and $\mathrm{Al}_{2} \mathrm{O}_{3}$ can be regarded as a structural promoter. As a porous oxide, alumina also provides a high surface area, but as mentioned earlier, cannot be seen as a classical support in commercial $\mathrm{Cu} / \mathrm{ZnO} / \mathrm{Al}_{2} \mathrm{O}_{3}$ catalysts. Many other oxides have been tested to find $\mathrm{Cu} / \mathrm{ZnO} / \mathrm{X}$ systems with improved catalytic properties, e.g. by combinatorial approaches [82]. In the field of MSR catalysts, Breen and Ross [83] compared a number of $\mathrm{Cu} / \mathrm{ZnO} / \mathrm{X}$ materials $\left(\mathrm{X}=\mathrm{Al}_{2} \mathrm{O}_{3}, \mathrm{ZrO}_{2}, \mathrm{La}_{2} \mathrm{O}_{3}, \mathrm{Y}_{2} \mathrm{O}_{3}\right)$ of different composition and prepared by different precipitation sequences. They concluded that $\mathrm{ZrO}_{2}$ is superior to $\mathrm{Al}_{2} \mathrm{O}_{3}$ as an oxide component in $\mathrm{Cu} / \mathrm{ZnO}$-based MSR catalysts. In addition to these $\mathrm{Cu} / \mathrm{ZnO} / \mathrm{ZrO}_{2}$ catalysts, also $\mathrm{Cu} / \mathrm{ZnO} / \mathrm{Al}_{2} \mathrm{O}_{3}$ composites prepared from layered double hydroxide precursors will be discussed in this section, since their microstructure and composition is markedly different from the 
commercial low- $\mathrm{Al}_{2} \mathrm{O}_{3}$ promoted $\mathrm{Cu} / \mathrm{ZnO}$ system described above. It is noted that also other oxides than $\mathrm{Al}_{2} \mathrm{O}_{3}$ or $\mathrm{ZrO}_{2}$ like for instance $\mathrm{SiO}_{2}$ [84], and also carbon $[85,86]$ were used to prepare active $\mathrm{Cu} / \mathrm{ZnO}$ MSR catalysts.

Layered double hydroxides (LDHs) or hydrotalcite-like compounds are hydroxy-carbonate precursors, which can be derived from the naturally occurring $\mathrm{Mg}$ - $\mathrm{Al}$ salt hydrotalcite, $\mathrm{Mg}_{1-\mathrm{x}} \mathrm{Al}_{\mathrm{x}}(\mathrm{OH})_{2}\left(\mathrm{CO}_{3}\right)_{2 / \mathrm{x}}$. $\mathrm{m} \mathrm{H}_{2} \mathrm{O}(0.25<\mathrm{x}<0.40)$. $\mathrm{Mg}$ and $\mathrm{Al}$ form layers of edge-sharing $(\mathrm{Mg}, \mathrm{Al})(\mathrm{OH})_{6}$ octahedra. The $\mathrm{H}$-atoms point to the interlayer space, where also the carbonate anions are located. Carbonate ions (or other anions) are needed in the structure to compensate for the extra positive charge introduced by the trivalent $\mathrm{Al}^{3+}$ ions. LDHs are wellestablished precursor compounds for synthesis of various catalysts $[87,88]$. They are especially interesting due to their ability to isomorphously substitute $\mathrm{Mg}^{2+}$ as well as $\mathrm{Al}^{3+}$ by other bi- or trivalent cations, in particular those from the first row of transition metals. Thus, they are very attractive precursors for $\mathrm{Cu}-\mathrm{Zn}-\mathrm{Al}$ catalysts as they can provide a perfect atomic distribution of all metal species in one single-phase precursor compound and should yield structurally uniform catalysts of high $\mathrm{Cu}$ dispersion and enhanced interaction between $\mathrm{Cu}$ metal and the $\mathrm{Zn}, \mathrm{Al}$ oxide phase.

Several studies have shown that $\mathrm{Cu}, \mathrm{Zn}, \mathrm{Al} \mathrm{LDH}$ precursors or precursor mixtures containing the LDH phase can indeed be decomposed into highly active MSR catalysts $[18,89,90]$. LDHs are typically and most easily prepared by co-precipitation, similar to the zincian malachite precursor of the methanol synthesis catalyst (see 
above). Preparation of phase-pure $\mathrm{Cu}, \mathrm{Zn}, \mathrm{Al} \mathrm{LDHs}$ requires a modified metal composition with an increase in $\mathrm{Al}$ and a decrease in $\mathrm{Cu}$ content. The former is necessary to provide enough trivalent cations, which should exceed around $1 / 4$ of the total metal cations. Thus Al cannot be regarded as a structural promoter phase any more, but rather is an integral component of the oxide phase in the final catalyst. The latter is to suppress formation of $\mathrm{Cu}$-rich malachite-like phases (desired in case of the industrial methanol synthesis catalyst), which is favored by $\mathrm{Cu}^{2+}$ due to the tendency of the $\mathrm{d}^{9}$ system to crystallize in Jahn-Teller distorted $4+2$ coordination rather than in the more regular LDH environment. Usually, no extended ageing period is needed to crystallize LDH phases from the precipitate.

$\mathrm{Cu}$-rich phase-pure LDH precursors (up to 49 at.- $\% \mathrm{Cu}$ ) can be prepared by such a modified direct co-precipitation and yield $\mathrm{Cu} / \mathrm{ZnAl}_{2} \mathrm{O}_{4}$-type catalysts [91]. These catalysts exhibit a different microstructure than that of the industrial $\mathrm{Cu} / \mathrm{ZnO} / \mathrm{Al}_{2} \mathrm{O}_{3}$ catalyst shown in Figure 2. Despite a smaller average $\mathrm{Cu}$ particle size observed in the ex-LDH material, which is a result of the lower total $\mathrm{Cu}$ content and the perfect cation distribution in the precursor, the accessible $\mathrm{Cu}$ surface area is considerable lower, around $5 \mathrm{~m}^{2} \mathrm{~g}^{-1}$. This is a result of the much stronger embedment of the small metal particles in the $\mathrm{ZnAl}_{2} \mathrm{O}_{4}$ matrix. After calcinations at $603 \mathrm{~K}$ and reduction, the interface-to-surface ratio was determined to be $89 \%$ compared to ca. $35 \%$ for the industrial system. The major challenge in the preparation of such ex- $\mathrm{LDH} \mathrm{Cu} / \mathrm{ZnAl}_{2} \mathrm{O}_{4}$ catalyst can thus be seen to optimize the "nuts-in-chocolate"-like morphology by adjust- 
ing the $\mathrm{Cu}$ particle size, the degree of embedment and the precursor platelet thickness in order to find the proper compromise between $\mathrm{Cu}$ metal-oxide interactions and $\mathrm{Cu}$ dispersion. Tang et al. [89] reported a surprisingly high accessible $\mathrm{SA}_{\mathrm{Cu}}$ of $39 \mathrm{~m}^{2} \mathrm{~g}^{-1}$ for a LDHderived $\mathrm{Cu} / \mathrm{ZnO} / \mathrm{Al}_{2} \mathrm{O}_{3}$ catalyst $(\mathrm{Cu}: \mathrm{Zn}: \mathrm{Al}=37: 15: 48)$ after calcination of the precursor at elevated temperature of $873 \mathrm{~K}$ associated with the crystallization of spinel-type oxides and the complete decomposition of all carbonate on the sample. A microemulsion approach for the precipitation of the precursor to "nano-cast" the platelet morphology of the LDH phase has also been shown to be promising in this direction as it increases $\mathrm{SA}_{\mathrm{Cu}}$ from 8 to $14 \mathrm{~m}^{2} \mathrm{~g}^{-1}$ compared to a conventionally co-precipitated ex- $\mathrm{LDH} \mathrm{Cu} / \mathrm{ZnAl}_{2} \mathrm{O}_{4}$ catalyst $(\mathrm{Cu}: \mathrm{Zn}: \mathrm{Al}=50: 17: 33)$ [92]. The MSR activity was improved, but did not scale linearly with $\mathrm{SA}_{\mathrm{Cu}}$ and was still lower compared to a commercial $\mathrm{Cu} / \mathrm{ZnO} / \mathrm{Al}_{2} \mathrm{O}_{3}$ catalyst of the type described above.

Highly active ex-LDH $\mathrm{Cu} / \mathrm{ZnO} / \mathrm{Al}_{2} \mathrm{O}_{3}$ catalysts have been reported by Turco et al. $[16,93,94]$ The authors applied a homogenous precipitation method of the chloride containing LDH followed by anion exchange with carbonate and investigated the structural and catalytic properties of the resulting catalysts. Calcination at $723 \mathrm{~K}$ leads to formation of $\mathrm{CuO}, \mathrm{ZnO}$, amorphous $\mathrm{Al}_{2} \mathrm{O}_{3}$ and probably also $\mathrm{Cu}$ and $\mathrm{Zn}$ aluminates. $\mathrm{Cu}$ contents were between 5 and $45 \%$ of all metal ions and $\mathrm{SA}_{\mathrm{Cu}} \mathrm{S}$ of up to $17.5 \mathrm{~m}^{2} \mathrm{~g}^{-1}$ could be achieved. The highest activity in oxidative MSR was observed for the composition $\mathrm{Cu}: \mathrm{Zn}: \mathrm{Al}=18: 33: 49$. This sample sample showed a conversion to 
$\mathrm{CO}$ near the detection limit of $0.01 \%$, which did not increase significantly with temperature between 473 and $673 \mathrm{~K}$.

Velu at al. $[18,95]$ have prepared $\mathrm{Cu}, \mathrm{Zn}, \mathrm{Al}-\mathrm{LDH}$ precursors by coprecipitation and calcined at $723 \mathrm{~K}$ to obtain $\mathrm{Cu} / \mathrm{ZnO} / \mathrm{Al}_{2} \mathrm{O}_{3}$ catalysts. Among these, the sample of the molar composition $\mathrm{Cu}: \mathrm{Zn}: \mathrm{Al}$ $=33: 43: 24$ showed the highest $\mathrm{Cu}$ dispersion. The high activity in oxidative MSR was stable over $25 \mathrm{~h}$ on stream. The authors also used $\mathrm{ZrO}_{2}$ as a replacement for $\mathrm{Al}_{2} \mathrm{O}_{3}$ and as an additive to the $\mathrm{Cu} / \mathrm{ZnO} / \mathrm{Al}_{2} \mathrm{O}_{3} \quad$ system. These $\mathrm{Cu} / \mathrm{ZnO} / \mathrm{ZrO}_{2}$ and $\mathrm{Cu} / \mathrm{ZnO} / \mathrm{Al}_{2} \mathrm{O}_{3} / \mathrm{ZrO}_{2}$ catalysts were prepared from aurichalcite and mixed aurichalcite/LDH precursors, respectively. The samples containing $\mathrm{ZrO}_{2}$ were more effective in oxidative MSR than the $\mathrm{ZrO}_{2}$ free samples. Copper-zirconia interactions, in particular $\mathrm{Cu}-\mathrm{O}-\mathrm{Zr}$ bonding, was found in these materials $[96,97]$. $\mathrm{Cu}$ was easier to reduce in the presence of $\mathrm{ZrO}_{2}$ suggesting an effect of the promoter oxide on the redox-chemistry of $\mathrm{Cu}$. $\mathrm{A} \mathrm{Cu}-\mathrm{ZrO}_{2}$ synergetic effect was proposed to be responsible for the better catalytic performance of the $\mathrm{ZrO}_{2}$-containing samples probably by adjusting the $\mathrm{Cu}^{0} / \mathrm{Cu}^{+}$ ratio under working conditions (see below). Such an effect of the presence of $\mathrm{ZrO}_{2}$ on the ratio of $\mathrm{Cu}^{0} / \mathrm{Cu}^{\text {oxidized }}$ at the catalyst surface was previously suggested by Breen and Ross on basis of modified redox-chemistry of $\mathrm{Cu}$ detected by temperature programmed reduction (TPR) [98]. Interestingly, a decreased reducibility of $\mathrm{Cu}$ was observed for their $\mathrm{ZrO}_{2}$-containing catalysts and ascribed to the presence of the promoter. The authors observed in their study that $\mathrm{Cu} / \mathrm{ZnO} / \mathrm{ZrO}_{2}$ catalysts were more active than $\mathrm{Cu} / \mathrm{ZnO} / \mathrm{Al}_{2} \mathrm{O}_{3}$ and 
the material could be further improved by addition of alumina and yttria. The interactions between $\mathrm{Cu}$ metal and zirconia are discussed in more detail below for $\mathrm{ZnO}$-free $\mathrm{Cu} / \mathrm{ZrO}_{2}$ catalysts.

Agrell et al. [15] prepared and characterized several $\mathrm{Cu} / \mathrm{ZnO}$ catalysts without and with addition of $\mathrm{Al}_{2} \mathrm{O}_{3}$ and/or $\mathrm{ZrO}_{2}$ by coprecipitation and used them in MSR. Among these samples, the $\mathrm{ZrO}_{2}$-containing systems showed the highest $\mathrm{Cu}$ dispersions and best MSR performances. The $\mathrm{Cu} / \mathrm{ZnO} / \mathrm{ZrO}_{2} / \mathrm{Al}_{2} \mathrm{O}_{3}$ catalyst also showed a high stability in POM activity upon redox cycling compared to the binary $\mathrm{Cu} / \mathrm{ZnO}$ sample, suggesting again an influence of $\mathrm{ZrO}_{2}$ on the redox properties of $\mathrm{Cu}$.

Matsumura and Ishibe [99] used $\mathrm{Cu} / \mathrm{ZnO} / \mathrm{ZrO}_{2}$ for high temperature MSR at $673 \mathrm{~K}$ and compared it to binary $\mathrm{Cu} / \mathrm{ZnO}$ and $\mathrm{Cu} / \mathrm{ZrO}_{2}$ (all 30 wt.-\% CuO after calcination). They observed an increased BET surface area and smaller particles in their $\mathrm{Cu} / \mathrm{ZnO} / \mathrm{ZrO}_{2}$ sample compared to binary $\mathrm{Cu} / \mathrm{ZnO}$. The catalytic activity was more stable than that of a commercial $\mathrm{Cu} / \mathrm{ZnO} / \mathrm{Al}_{2} \mathrm{O}_{3}$ catalyst. Interestingly, deactivation was found to be accompanied by the growth of the oxide particles rather than by $\mathrm{Cu}$ sintering.

An activity-promoting role of $\mathrm{ZrO}_{2}$ was also reported by Jones and Hagelin-Weaver in a series of $\mathrm{Cu} / \mathrm{ZnO} / \mathrm{X}$ catalysts $\left(\mathrm{X}=\mathrm{ZrO}_{2}, \mathrm{CeO}_{2}\right.$, $\mathrm{Al}_{2} \mathrm{O}_{3}$ ) prepared by impregnation [100]. The best sample was a $\mathrm{Cu} / \mathrm{ZnO} / \mathrm{ZrO}_{2} / \mathrm{Al}_{2} \mathrm{O}_{3}$ catalyst, which was most active and showed lowest $\mathrm{CO}$ selectivity. This catalyst was prepared by coimpregnation of $\mathrm{Cu}$ and $\mathrm{Zn}$ onto a mixture of zirconia and alumina 
nanoparticles and the good catalytic properties were related to the presence of the monoclinic polymorph of $\mathrm{ZrO}_{2}$.

\section{ZnO-free Cu-based catalysts}

Among the $\mathrm{ZnO}$-free $\mathrm{Cu}$-based catalysts, those comprising $\mathrm{ZrO}_{2}$ and $\mathrm{CeO}_{2}$ are the most studied systems and will be in the focus of this section. Combinations of $\mathrm{Cu}$ with chromia [101-103], or manganese oxide [101] promoters or $\mathrm{Cu}$ on silica supports [104] have also been used in MSR. Depending on the Cu content and the method of preparation - co-precipitation, sol-gel chemistry or impregnation - these catalysts can be either obtained in form of truly supported or bulk catalysts similar to the industrial $\mathrm{Cu} / \mathrm{ZnO} / \mathrm{Al}_{2} \mathrm{O}_{3}$ system. Also skeletal $\mathrm{Cu}$ catalysts are known to be active in MSR, which can be prepared from $\mathrm{Cu}$-containing alloys by selective leaching. These materials are prepared employing intermetallic compounds as precursor phases and are discussed in more detail in the second part of this chapter.

In the last years there has been growing interest in $\mathrm{ZnO}$-free $\mathrm{Cu} / \mathrm{ZrO}_{2}$ as catalyst for the MSR reaction. Already in the $1980 \mathrm{~s}$, higher conversions of methanol were reported for $\mathrm{Cu} / \mathrm{ZrO}_{2}$ in comparison with $\mathrm{Cu} / \mathrm{SiO}_{2}$ prepared by impregnation methods $[105,106]$. $\mathrm{Cu} / \mathrm{ZrO}_{2}$ catalysts prepared by precipitation showed turnover frequencies comparable to a $\mathrm{Cu} / \mathrm{ZnO}$ catalyst [98]. The lower total activity for the $\mathrm{Cu} / \mathrm{ZrO}_{2}$ catalysts was ascribed to lower $\mathrm{SA}_{\mathrm{Cu}}$ in these catalysts. Ritzkopf et al. [20] successfully applied a microemulsion technique using the water droplets of a water-in-oil system to con- 
fine the reaction space for co-precipitation. They obtained intimately mixed $\mathrm{CuO} / \mathrm{ZrO}_{2}$ particles with $4-16$ wt.-\% $\mathrm{Cu}$ and a particle size of less than $10 \mathrm{~nm}$. At high temperature this catalyst showed activity levels identical to a commercial catalyst, but the level of produced $\mathrm{CO}$ was substantially reduced. At $573 \mathrm{~K}$ and ca. $90 \%$ conversion the $\mathrm{CO}$ concentration in the effluent was only ca. one fifth compared to the $\mathrm{Cu} / \mathrm{ZnO}$ reference. In contrast to the commercial catalyst, oxidized $\mathrm{Cu}$ species were detected by X-ray photoemission spectroscopy (XPS) on the surface of the $\mathrm{Cu} / \mathrm{ZrO}_{2}$ catalyst after reaction, supporting the stabilizing role of $\mathrm{ZrO}_{2}$ on oxidized $\mathrm{Cu}$ species, which was also observed for $\mathrm{ZrO}_{2}$-promoted $\mathrm{Cu} / \mathrm{ZnO} /\left(\mathrm{Al}_{2} \mathrm{O}_{3}\right)$ catalysts (see above). Such oxidized $\mathrm{Cu}^{+}$species are discussed to play an important role in the MSR reaction (see below).

Purnama et al. [19] reported about a $\mathrm{Cu} / \mathrm{ZrO}_{2}$ catalyst prepared by a templating procedure $(8.5 \mathrm{wt} .-\% \mathrm{Cu})$ which showed higher activity as a function of $\mathrm{W}_{\mathrm{Cu}} / \mathrm{F}$ and better stability during MSR as well as a lower production of $\mathrm{CO}$ compared to a commercial $\mathrm{Cu} / \mathrm{ZnO} / \mathrm{Al}_{2} \mathrm{O}_{3}$ sample. This sample showed a complex activation behavior if oxygen pulses were added to the feed after certain periods of time on stream. Szizybalski et al. [107] prepared a $\mathrm{Cu} / \mathrm{ZrO}_{2}$ catalyst with 8.9 mol-\% $\mathrm{Cu}$ after calcination by a precipitation method and investigated this phenomenon more closely. The calcined catalyst contained small and disordered $\mathrm{CuO}$ particles rather than $\mathrm{Cu}^{2+}$ incorporated in to the zirconia lattice. Again, a decreased reducibility was observed. By means of in situ $\mathrm{Cu}$ K-edge X-ray absorption spectroscopy, a significant amount of residual oxygen was detected in the $\mathrm{Cu}$ phase 
after reduction at $523 \mathrm{~K}$, which could only be removed by treating the catalyst with hydrogen at $673 \mathrm{~K}$. If oxygen was added to the feed during MSR, an increase of this residual oxygen concentration was detected after re-reduction in the feed, which was accompanied by an increase in MSR activity. Thus, a correlation of the amount of oxygen remaining in the copper particles and the catalytic activity was proposed leading to the conclusion that there must be a different metal support interaction of $\mathrm{Cu} / \mathrm{ZrO} \mathrm{r}_{2}$ compared to $\mathrm{Cu} / \mathrm{ZnO}$ catalysts, where such correlation was not observed.

Similar to the $\mathrm{Cu} / \mathrm{ZnO}$ system, a high $\mathrm{Cu}$ loading of 80 wt.- $\%$ was reported to yield the most active material if co-precipitation and nitrate solutions were used for preparation of $\mathrm{Cu} / \mathrm{ZrO}_{2}$ catalysts [108]. Yao et al. [109] prepared $\mathrm{Cu} / \mathrm{ZrO}_{2}$ catalysts with this composition by four different methods and showed that the catalysts prepared by coprecipitation revealed a higher conversion compared with the ones prepared by impregnation. The best results were obtained by an oxalate gel co-precipitation method and for a calcination temperature of $823 \mathrm{~K}$ [110]. In this catalyst, a thin layer of monoclinic $\mathrm{ZrO}_{2}$ was detected on a bulk of tetragonal $\mathrm{ZrO}_{2}$. With increasing calcination temperature the amount of monoclinic $\mathrm{ZrO}_{2}$ increased accompanied by decreasing conversions.

$\mathrm{Wu}$ et al. [111] have studied the effect of $\mathrm{ZnO}$ and $\mathrm{ZrO}_{2}$ on the catalytic properties of $\mathrm{Cu}$ in MSR by comparing pure $\mathrm{Cu}$ with inverse $\mathrm{ZnO} / \mathrm{Cu}$ and $\mathrm{ZrO}_{2} / \mathrm{Cu}$ model systems. Both oxides were found to enhance the activity of $\mathrm{Cu}$ and to stabilize the $\mathrm{Cu}$ particles against aggregation and sintering. Moreover, the presence of the oxides result- 
ed in a stabilization of $\mathrm{Cu}^{+}$species at the surface of the catalyst. The authors concluded that $\mathrm{ZrO}_{2}$ is the superior promoter oxide for the Cu-based MSR catalyst.

Also $\mathrm{CeO}_{2}$ turned out to be a promising oxide component for $\mathrm{Cu}$ based MSR catalysts. $\mathrm{Cu} / \mathrm{CeO}_{2}$ catalysts were prepared by Liu et al. $[21,112,113]$ using a co-precipitation method and calcination at 723 $\mathrm{K}$. By this treatment up to $20 \% \mathrm{Cu}^{2+}$ could be incorporated into the ceria lattice. After reduction a $\mathrm{Cu} / \mathrm{CeO}_{2}$ catalyst was obtained (3.9 wt.- $\% \mathrm{Cu}$ ), which was more active than $\mathrm{Cu} / \mathrm{ZnO}$ and $\mathrm{Cu} / \mathrm{Zn} / \mathrm{Al}_{2} \mathrm{O}_{3}$ catalysts of the same low $\mathrm{Cu}$ loading. After deactivation the initial activity could be regenerated by re-calcination and reduction. The high activity was ascribed to strong $\mathrm{Cu}$-oxide interactions and related to the high oxygen mobility of the ceria support. Also mixed $\mathrm{CeO}_{2} / \mathrm{ZrO}_{2}$ [114] or $\mathrm{Zr}$ - [115] or Gd-doped [116] ceria was used as support for $\mathrm{Cu}$-based MSR catalysts.

The increasing $\mathrm{Cu}$-oxide interactions when going from $\mathrm{Cu} / \mathrm{ZnO}$ over $\mathrm{Cu} / \mathrm{ZrO}_{2}$ to $\mathrm{Cu} / \mathrm{CeO}_{2}$ are also reflected in a more and more enhanced substitution chemistry in the oxide phase at higher temperatures. While $\mathrm{Zn}^{2+}$ and $\mathrm{Cu}^{2+}$ show a common solid state chemistry only on the stage of the precipitated catalyst precursor, e.g. in form of a joint cationic lattice of hydroxy carbonate phases (see above), significant isomorphous substitution of $\mathrm{Cu}^{2+}$ in $\mathrm{ZnO}$ is, despite the match of cationic charge and similar ionic radii, hardly observed. The reason for this low degree of solid state solubility is most likely the tetrahedral coordination environment of $\mathrm{Zn}^{2+}$-sites in $\mathrm{ZnO}$, which is unfavorable for $\mathrm{Cu}^{2+}$, which preferrs a Jahn-Teller-distorted octahedral 
$4+2$ coordination. Incorporation of $\mathrm{M}^{2+}$ cations, like $\mathrm{Ca}^{2+}$, in the zirconia lattice on the other hand is well-know and can stabilize the higher symmetric polymorphs of $\mathrm{ZrO}_{2}$. It was reported that also $\mathrm{Cu}^{2+}$ can substitute $\mathrm{Zr}^{4+}$ and has an effect on the zirconia phase composition [117], but this effect may not play a role for preparation of $\mathrm{Cu}$ based MSR catalysts, where calcination temperatures are usually low and $\mathrm{Cu}$ was observed to be present rather in form of highly dispersed $\mathrm{CuO}$ [107]. In case of $\mathrm{CeO}_{2}$, however, clear evidence for the formation of a $\mathrm{Ce}_{1-\mathrm{x}} \mathrm{Cu}_{\mathrm{x}} \mathrm{O}_{2}$ solid solution during catalyst preparation applying a calcination temperature of $723 \mathrm{~K}$ was presented by Liu et al. [21,112,113] Both materials, $\mathrm{ZrO}_{2}$ and $\mathrm{CeO}_{2}$, are known to easily form sub-stoichiometric metal-to-oxygen ratios and the charge mismatch upon incorporation of $\mathrm{Cu}^{2+}$ can be compensated by formation of oxygen vacancies. Although highly substituted bulk phases are not likely to form under MSR conditions or even in oxidative MSR atmosphere and thus themselves are probably not relevant for catalysis, these considerations still show that differences in the solid state reactivity of $\mathrm{Cu}$ with different oxides exist. Under oxidative conditions the systems tend to form mixed oxides by beginning oxidation of the $\mathrm{Cu}$ metal, while under reducing conditions the systems tend to form an alloy by beginning reduction of the oxide. The connection of the redox chemistry of the $\mathrm{Cu}$ phase and its interaction with the oxide component was observed by many researchers. From the substitution chemistry of the bulk oxide phases, it is understandable that $\mathrm{ZrO}_{2}$ and $\mathrm{CeO}_{2}$ have a stabilizing effect on oxidized $\mathrm{Cu}$ leading to a 
higher reduction temperature, while this effect is not observed for $\mathrm{ZnO}[118]$.

Strengthened interactions between $\mathrm{Cu}$ metal and the oxide are obviously important for the stability of the catalysts as they hinder mobility of the $\mathrm{Cu}$ particles and thus decrease the tendency for thermal sintering. Furthermore, these interactions may be important for the accessibility of higher $\mathrm{Cu}$ oxidation states at given conditions, or more generally for the ease of oxygen incorporation into the $\mathrm{Cu}$ lattice (see below). Another practical aspect is that the re-dispersion of the $\mathrm{Cu}$ phase by oxidative regeneration will work much better for those systems which can form mixed oxides like $\mathrm{Cu} / \mathrm{CeO}_{2}$ (stronger interactions) compared to those which cannot easily form mixed phases like $\mathrm{Cu} / \mathrm{ZnO}$.

In an optimized $\mathrm{Cu}$-based catalyst for MSR, the beneficial effect of redox promoting oxides on the $\mathrm{Cu}$ phase should be combined with the proven structural promoting effects of the less redox active $\mathrm{ZnO} / \mathrm{Al}_{2} \mathrm{O}_{3}$ components.

\section{The active form of $\mathrm{Cu}$ under MSR conditions}

The question to what is the active site of Cu-based catalysts in MSR is still unclear and debated in literature. Similar to the methanol synthesis reaction either metallic $\mathrm{Cu}^{0}$ sites, oxidized $\mathrm{Cu}^{+}$sites dispersed on the oxide component or at the $\mathrm{Cu}$-oxide interface or a combination of both kinds of sites are discussed to contribute to the active ensembles at the $\mathrm{Cu}$ surface. Furthermore, the oxidic surface of the refractory component may take part in the catalytic reaction as well 
as providing adsorption sites for the oxygenate-bonded species [119], while hydrogen is probably adsorbed at the metallic $\mathrm{Cu}$ surface.

Clearly, $\mathrm{SA}_{\mathrm{Cu}}$ is among the most important factors determining the activity of a $\mathrm{Cu}$-based catalyst in MSR, indicating the importance of proper balance of $\mathrm{Cu}$ dispersion and loading and thus of catalyst preparation. Sufficient $\mathrm{SA}_{\mathrm{Cu}}$ is a prerequisite for a high performance $\mathrm{Cu}$-based MSR catalyst, but the metallic $\mathrm{Cu}$ surface area measured by $\mathrm{N}_{2} \mathrm{O}$ decomposition does not scale linearly with activity in all cases, and turnover frequencies - which were calculated using $\mathrm{SA}_{\mathrm{Cu}}$ as a count of active sites - vary even for the same sample after different pre-treatments [120]. Thus, other factors intrinsic to the $\mathrm{Cu}$ phase and not detectable by the $\mathrm{N}_{2} \mathrm{O}$ titration method also contribute to the MSR activity. There are two major views discussed in literature relating these intrinsic factors either to the variable oxidation state of $\mathrm{Cu}$, in particular to the in situ adjustment of the $\mathrm{Cu}^{0} / \mathrm{Cu}^{+}$ratio at the catalyst's surface, or to the defect structure and varying amount of disorder in metallic $\mathrm{Cu}$ depending on the microstructure and preparation history of the catalyst. As we will see, these views are not necessarily contradicting each other.

Changes of the oxidation state of $\mathrm{Cu}$ are to be considered in particular in oxidative MSR due to the presence of gas phase oxygen. It has been tried to answer the question of the oxidation state of $\mathrm{Cu}$ under (oxidative) MSR conditions by post-reaction characterization as well as by in situ investigations with sometimes different results depending on the feed gas compositions, the catalyst material studied and 
the characterization method used. Near-surface sensitive techniques like X-ray photoelectron spectroscopy (XPS) are well-suited to investigate the oxidation state of the near-surface of a $\mathrm{Cu}$-based MSR catalyst, although the discrimination of $\mathrm{Cu}^{+}$and $\mathrm{Cu}^{0}$ may be challenging on basis of the core level spectra. It is noted that contact to air has to be strictly avoided to obtain reliable results as highly dispersed $\mathrm{Cu}$ particles are prone to oxidation in air. Another drawback is that with laboratory XPS only ex situ investigations are possible and potential changes of the catalyst upon cooling and evacuation have to be taken into account. X-ray diffraction and X-ray absorption spectroscopy are also widely used to characterize the $\mathrm{Cu}$ phase in MSR catalysts. With these methods in situ investigations are possible, but they lack surface sensitivity. Another general aspect to be considered when reporting $\mathrm{Cu}^{0} / \mathrm{Cu}^{\text {oxidized }}$ ratios is the homogeneity of the catalyst studied. If different $\mathrm{Cu}$ species are present in the catalyst, e.g. larger $\mathrm{Cu}$ particles as well as highly dispersed $\mathrm{Cu}$ clusters, additional characterization information is needed to identify the effect of the individual $\mathrm{Cu}$ species on the results.

Agrell et al. [15] studied the near-surface region of a $\mathrm{Cu} / \mathrm{ZnO} / \mathrm{ZrO}_{2} / \mathrm{Al}_{2} \mathrm{O}_{3}$ catalyst by XPS after simulating oxidative MSR reaction conditions in the pre-treatment chamber. They reported the presence of metallic $\mathrm{Cu}^{0}$ after reduction and formation of oxidized $\mathrm{Cu}^{+}$species after exposure to a $\mathrm{O}_{2} / \mathrm{MeOH}$ atmosphere (1:2). In contrast, Goodby and Pemberton [121], who used pure MSR atmosphere without oxygen and a commercial $\mathrm{Cu} / \mathrm{ZnO} / \mathrm{Al}_{2} \mathrm{O}_{3}$ catalyst, found still about $7 \% \mathrm{Cu}^{+}$at the surface after reduction in hydrogen, 
but the catalyst was fully reduced after using it in MSR. Raimondi et al. [122] used a similar method and found that the oxidation state of $\mathrm{Cu}$ in a commercial $\mathrm{Cu} / \mathrm{ZnO} / \mathrm{Al}_{2} \mathrm{O}_{3}$ catalyst is a function of feed gas composition. At slightly sub-stoichiometric $\mathrm{O}_{2}: \mathrm{MeOH}$ ratio $\mathrm{Cu}^{+}$was predominant only at temperatures below $510 \mathrm{~K}$. At higher temperatures $\mathrm{Cu}$ was reduced by $\mathrm{MeOH}$ to its metallic state. $\mathrm{H}_{2}$ was produced only when $\mathrm{Cu}^{+}$or $\mathrm{Cu}^{0}$ were detected, while $\mathrm{Cu}^{2+}$ formed at higher $\mathrm{O}_{2}$ partial pressures was inactive and led to $\mathrm{MeOH}$ combustion. Using a sub-monolayer $\mathrm{Cu}$ on thin oriented $\mathrm{ZnO}$ films as model catalyst the same group showed that aggregation of the $\mathrm{Cu}$ islands is promoted by the presence of $\mathrm{O}_{2}$ if $\mathrm{Cu}$ was in the metallic state at a $\mathrm{O}_{2}: \mathrm{MeOH}$ ratio below 0.25 at $550 \mathrm{~K}$. At higher $\mathrm{O}_{2}$ concentrations $\mathrm{Cu}$ is oxidized and the aggregation is less pronounced suggesting an effect of the oxidation state of $\mathrm{Cu}$ on the $\mathrm{Cu}-\mathrm{ZnO}$ interactions [123]. Reitz at al. [124] used bulk-sensitive in situ X-ray absorption spectroscopy to study the oxidation state of $\mathrm{Cu}$ under different conditions in the presence of methanol, steam and oxygen. They observed MSR-inactive $\mathrm{Cu}^{2+}$ at low $\mathrm{O}_{2}$ conversions and found $\mathrm{H}_{2}$ production only if metallic $\mathrm{Cu}$ was detected. $\mathrm{Cu}^{+}$was detected as an intermediate during the reduction of $\mathrm{Cu}^{2+}$ to $\mathrm{Cu}^{0}$.

It is not a surprise that the oxidation state of $\mathrm{Cu}$ is a function of the oxidation power of the gas feed, especially of the $\mathrm{O}_{2}$ concentration if oxidative MSR is used. Knop-Gericke et al. [125] have shown the importance and complexity of the dynamic near-surface $\mathrm{Cu}-\mathrm{O}$ chemistry by high pressure in situ XPS for the $\mathrm{MeOH}$ oxidation reaction on $\mathrm{Cu}$ foil. With increasing $\mathrm{O}_{2}: \mathrm{MeOH}$ ratio the in situ formed $\mathrm{Cu}$ 
surface could vary from metal via sub-oxide to $\mathrm{Cu}(\mathrm{I})$-oxide like species. The most active and selective state (to formaldehyde) observed in this study was a disordered $\mathrm{Cu}^{0}$ surface modified in situ by subsurface oxygen of a composition near $\mathrm{Cu}_{\sim 10} \mathrm{O}$ stressing that the pure $\mathrm{Cu}^{0}$ metal and bulk $\mathrm{Cu}_{2} \mathrm{O}$ phases are not sufficient to fully describe the surface chemistry of the $\mathrm{Cu}-\mathrm{O}$ system. It is noted that the active surface phase was only observed in situ and did not form under UHV conditions.

It is not only the gas phase composition, which determines the oxidation state of $\mathrm{Cu}$ under MSR conditions. Also the catalyst formulation plays a significant role. It was already mentioned above that the presence of $\mathrm{ZrO}_{2}$ generally decreases the reducibility of $\mathrm{CuO}$ and can stabilize $\mathrm{Cu}^{+}$compared to $\mathrm{ZrO}_{2}$-free systems at given MSR conditions. Such $\mathrm{Cu}^{+}$centers are often discussed to be the active sites of (oxidative) MSR in the context of a redox-mechanism corresponding to the reverse of a reaction proposed for methanol synthesis by Klier [126], where $\mathrm{Cu}^{+}$centers incorporated in a $\mathrm{ZnO}$ matrix are suggested as active sites. The Busca group identified $\mathrm{Cu}^{+}$sites at the surface of $\mathrm{LDH}$-derived $\mathrm{Cu} / \mathrm{ZnO} / \mathrm{Al}_{2} \mathrm{O}_{3}$ catalysts using IR spectroscopic methods and discussed their role in oxidative MSR [90,127-129]. The second explanation for a varying intrinsic activity is the different amount of disorder in the metallic $\mathrm{Cu}$ phase. This disorder can manifest itself in form of detectable lattice strain, e.g., by line profile analysis of XRD peaks [17], ${ }^{63} \mathrm{Cu}-\mathrm{NMR}$ lines [65], or as an increased disorder parameter (Debye-Waller-factor) derived from extended X-ray absorption fine structure (EXAFS) spectroscopy [120]. 
Strained copper has been shown theoretically [130] and experimentally [131] to have different adsorptive properties compared to unstrained surfaces. Strain, i.e. local variation in the lattice parameter, is known to shift the centre of the d-band and alter the interactions of metal surface and absorbate [132]. Alternatively, a modification of the electronic structure of $\mathrm{Cu}$ was also discussed to take place at the interface between $\mathrm{Cu}$ metal and the semiconducting oxide forming a Schottky junction [133].

Günter at al. [120] used in situ XRD and EXAFS and found a correlation of disorder in the $\mathrm{Cu}$ phase and the activity of a series of differently prepared $\mathrm{Cu} / \mathrm{ZnO}$ catalysts in MSR. Also the selectivity towards $\mathrm{CO}_{2}$ was affected. Kniep et al. [65] could show that the $\mathrm{Cu}$ phase in $\mathrm{Cu} / \mathrm{ZnO}$ catalysts prepared under otherwise identical conditions was more strained and more active in MSR if the precipitate was aged than without ageing. Also introduction of a microwave heating step [134] or reactive grinding [135] of the calcined $\mathrm{CuO} / \mathrm{ZnO}$ material was used to prepare strained and disordered and, thus, intrinsically more active $\mathrm{Cu}$ particles in the final MSR catalyst. A certain increase in disorder seems to be also achievable by postpreparation treatment as could be shown by in situ investigations (Fig. 8) [120]. Addition of oxygen to the MSR feed led to a transient breakdown of MSR activity ascribed to the formation of $\mathrm{CuO}$. After switching off the oxygen stream, the catalyst was re-reduced to $\mathrm{Cu}^{0}$ in the MSR feed and exhibited a higher conversion of methanol as well as lower selectivity to $\mathrm{CO}$, which was ascribed to an increase in structural disorder. Bulk- $\mathrm{Cu}_{2} \mathrm{O}$ was observed only as an intermediate 
during reduction. The origin of structural disorder in highly active $\mathrm{Cu} / \mathrm{ZnO}$ catalysts is thought to be the interface of the $\mathrm{Cu}^{0}$ clusters with the $\mathrm{ZnO}$ particles. Thus, enhancement of this interface contact may be beneficial for the activity of the catalyst, if not too much $\mathrm{SA}_{\mathrm{Cu}}$ is sacrificed.

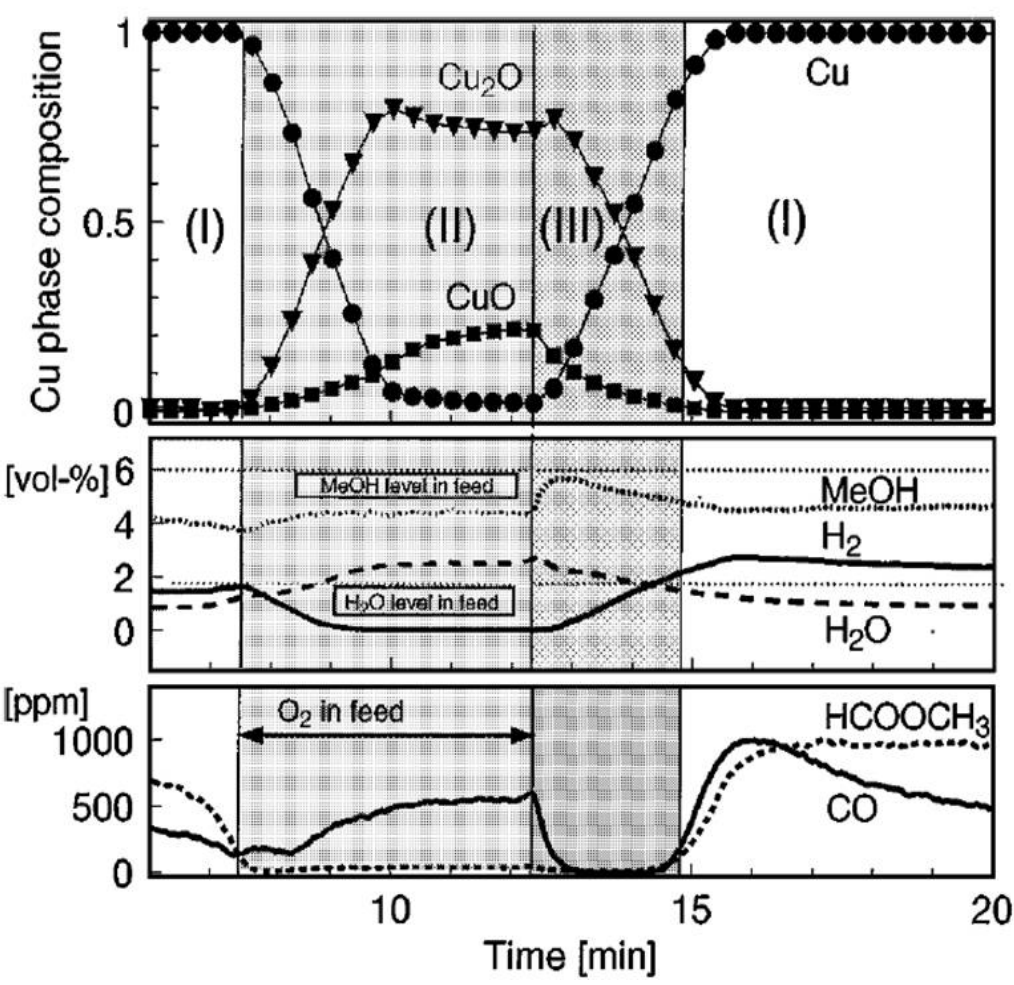

Fig. 8: Evolution of $\mathrm{Cu}$ phase composition of a $\mathrm{Cu} / \mathrm{ZnO}$ catalyst during oxygen addition cycles into steam reforming feed at $523 \mathrm{~K}$. Phase analysis was based on the corresponding X-ray absorption near edge structure (XANES) spectra. The two lower sections of the graph depict the evolution of the gas-phase in percent and ppm, respectively. Three transitions in bulk and gasphase composition are marked: (I) copper metal during steam reforming, (II) oxidation to of $\mathrm{Cu}$, (III) and re-reduction of $\mathrm{Cu}$ oxide. Reprinted from ref [120] with permission from Elsevier.

Accordingly, short addition of oxygen to a $\mathrm{Cu} / \mathrm{ZrO}_{2}$ MSR catalyst under working conditions was also shown to have an activating ef- 
fect on the $\mathrm{Cu}$ phase, which is even more pronounced and stable compared to $\mathrm{Cu} / \mathrm{ZnO}[19,107]$. In this case no significant lattice strain of $\mathrm{Cu}$ could be detected, but incorporation of oxygen in metallic $\mathrm{Cu}$ was observed (see above). Considering similar effects on the catalytic properties of $\mathrm{Cu}$ in these particular experiments but apparently different structural origins in $\mathrm{Cu} / \mathrm{ZnO}$ and $\mathrm{Cu} / \mathrm{ZrO}_{2}$, and taking into account the work addressing the oxidation state of $\mathrm{Cu}$, a general view on $\mathrm{Cu}$ in MSR emerges. The catalytic activity of $\mathrm{Cu}$ in MSR seems to be related to a non-equilibrium form of metallic $\mathrm{Cu}$. The deviation of the catalytically active surface from its ordered equilibrium form can be triggered by redox-chemistry as well as by a beneficial microstructural arrangement of the composite catalyst. The former relates to a distortion of the $\mathrm{Cu}$ lattice by oxygen dissolution and is a dynamic effect, which adjusts itself in situ. This effect can be measured by bulk methods as residual oxygen content in the $\mathrm{Cu}^{0}$ phase and may well influence the $\mathrm{Cu}^{0} / \mathrm{Cu}^{+}$ratio measured ex situ with surface sensitive techniques. The extent of this distortion is a function of the gas phase composition and the metal-oxide interactions. Oxygen incorporation is favored by increasing the oxidation power of the feed, e.g. by oxygen addition, and facilitated by strong (or synergetic) interactions of $\mathrm{Cu}$ and the oxide component like in $\mathrm{Cu} / \mathrm{ZrO}_{2}$. However, oxidation of $\mathrm{Cu}$ to a bulk oxide form $\left(\mathrm{Cu}_{2} \mathrm{O}\right)$ by a too strongly oxidizing atmosphere as well as formation of a mixed oxide phase (e.g. inactive $\mathrm{CuAl}_{2} \mathrm{O}_{4}$ ) by too strong interactions of $\mathrm{Cu}$ with the oxide has to be avoided. 
Deviation from equilibrium $\mathrm{Cu}$ due to static defects and lattice strain, on the other hand, can be introduced in the $\mathrm{Cu}$ particles by proper catalyst preparation aiming at kinetically trapping a distorted and defect-rich state of $\mathrm{Cu}$. In a microstructure with small particles, many $\mathrm{Cu}^{0}$-oxide interfaces like in the commercial $\mathrm{Cu} / \mathrm{ZnO} /\left(\mathrm{Al}_{2} \mathrm{O}_{3}\right)$ catalyst beneficially affect the $\mathrm{Cu}$ phase. In addition to the beneficial role of $\mathrm{Zn}^{2+}$ on $\mathrm{Cu}$ dispersion (see above), the interface of $\mathrm{Cu}$ metal and $\mathrm{ZnO}$ seems to be well suited to pin this favorable defect structure of $\mathrm{Cu}^{0}$.

\section{Intermetallic Compounds in Methanol Steam Re- forming}

Besides the Cu-based systems, different other systems, mainly based on palladium or platinum, have been explored as catalysts for the steam reforming of methanol. The driving force was to detect materials with higher stability against sintering and higher selectivity, i.e. lower CO partial pressures in the product [136].

Interestingly, the formation of intermetallic compounds is frequently observed in these metal-oxide supported systems and is very often connected with a significant increase in selectivity to $\mathrm{CO}_{2}$ [27]. An "intermetallic compound" is composed of two or more metallic elements and possesses a crystal structure which is different from the constituting elements and at least partly ordered [137,138]. "Compound" implies, that it is single-phase, which is not in contradiction to the often broad homogeneity ranges of intermetallic compounds. 
In contrast, the more familiar term "alloy" corresponds to a mixture of metals, intermetallic compounds and/or non-metals, and can consist of more than one phase. 


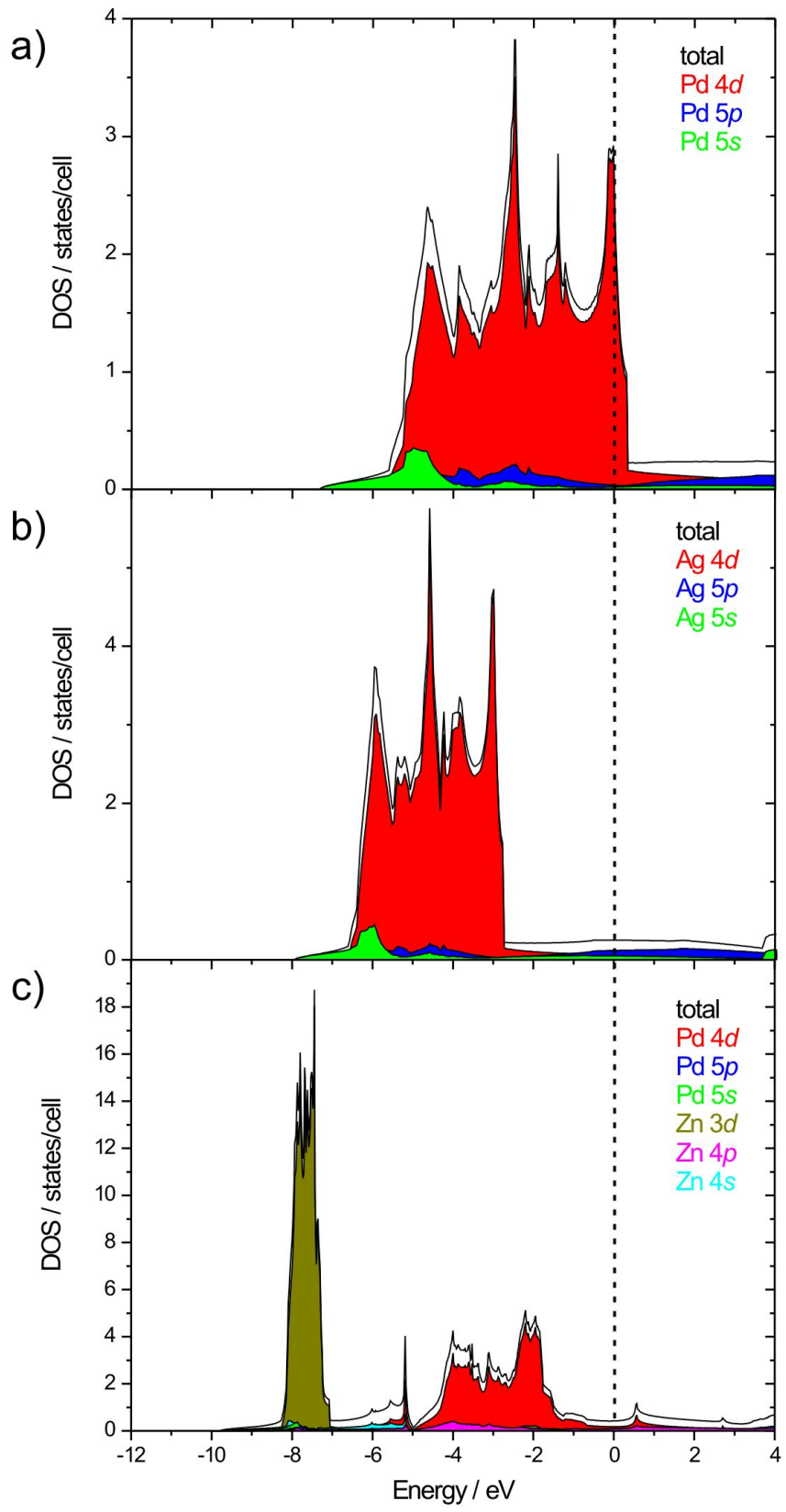

Figure 9: Density of states of metallic Pd (a), Ag (b) and the intermetallic compound $\mathrm{ZnPd}$ (c). Ag-Pd alloy formation leads to $d$-band filling intermediate between elemental Pd and Ag. In contrast, huge differences are revealed at the Fermi energy as well as in the width of the $\mathrm{Pd} d$-bands upon formation of the intermetallic compound $\mathrm{ZnPd}(\mathrm{c})$. 
Figure 9 demonstrates the huge consequences of an ordered intermetallic compound on the electronic structure of the catalytically active species. Opposed are the electronic densities of state (DOS) of Pd metal, Ag metal and the intermetallic compound $\mathrm{ZnPd}$ (often called PdZn but see [139]). By alloy-formation of e.g. Ag-Pd the total electron concentration per atom increases with increasing Ag-content, but the crystal structure does not change ( $\mathrm{Cu}$ type of crystal structure, space group $F m \overline{3} \mathrm{~m}$ ). As a consequence, the DOS remains very similar (so-called rigid-band approach) to that of elemental Pd but the $d$-bands are further populated until they reach the population of pure silver (Fig. 9b). On the other hand, the intermetallic compound $\mathrm{ZnPd}$ crystallizes in the ordered $\mathrm{CuAu}$ type of crystal structure (space group $\mathrm{P} 4 / \mathrm{mmm}$ ). The crystal structure is a direct consequence of the covalent chemical bonding within the intermetallic compound upon formation [139]. Interestingly, covalent interactions are quite common in intermetallic compounds, leading to a strong alteration of the electronic structure as seen in Fig. 9c. They are also displayed by the physical properties of the compounds [140-142]. Since a significant number of valence electrons are localized in the covalent bonds, the electrical conductivity is significantly reduced upon compound formation. An example is the well investigated $\theta$-phase, the intermetallic compound $\mathrm{CuAl}_{2}$ [142] in the system $\mathrm{Al}-\mathrm{Cu}$ shown in Fig. 10. 


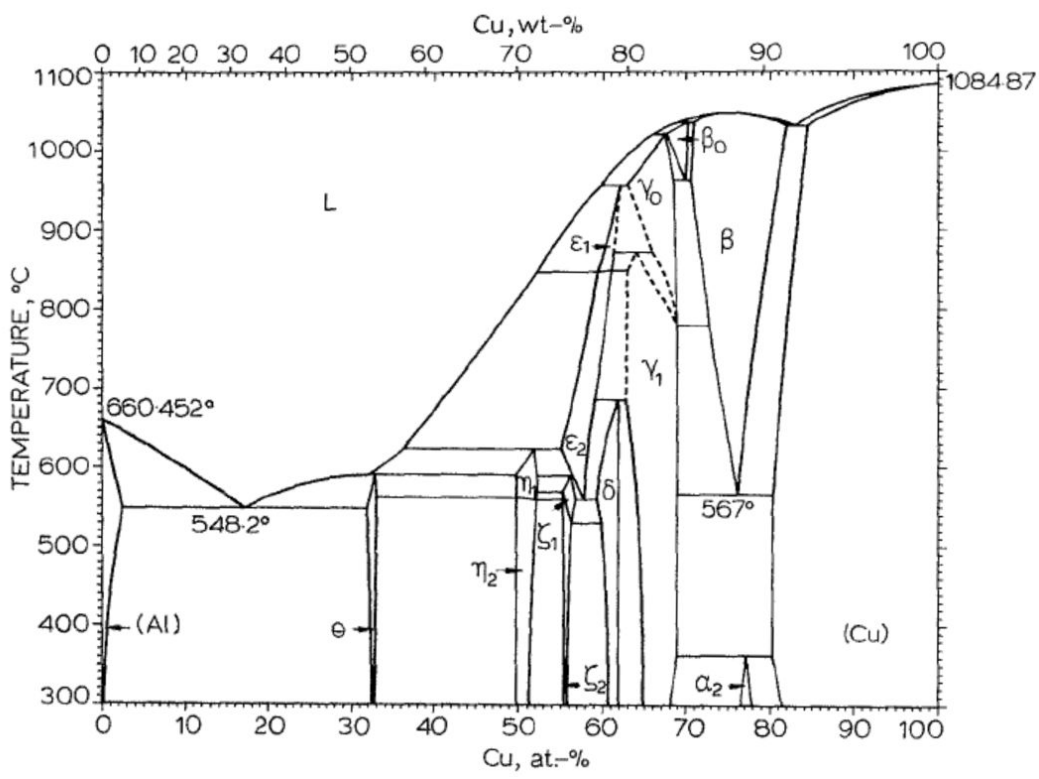

Fig. 10: Phase diagram of the system Al-Cu. Reprinted from Int. Met. Reviews 30, J.L. Murray, The aluminium-copper system, 211-233, with permission from ASM International ${ }^{\circledR}$. All rights reserved. www.asminternational.org

Both elements crystallize in the Cu-type of structure (cubic closed packed). Alloy formation takes place on the Al- as well as the $\mathrm{Cu}$ rich side. Up to 20 at.- $\%$ of $\mathrm{Al}$ can be dissolved in $\mathrm{Cu}$ without changing the crystal structure. Between the two alloys, a number of intermetallic compounds with different structures are formed. In $\mathrm{CuAl}_{2}$ the three-bonded $\mathrm{Al}$ atoms build covalent and interpenetrating $6^{3}$ nets. The $\mathrm{Cu}$ atoms are located in tetragonal antiprismatic cavities and interconnect the $6^{3}$ nets by eight three-centre bonds. This bonding situation is dramatically influencing the physical properties. In contrast to $\mathrm{Cu}$ and $\mathrm{Al}, \mathrm{CuAl}_{2}$ is no longer ductile, but brittle as glass - a property often observed for covalently bonded intermetallic compounds. Localization of the electrons in the covalent bonds re- 
duces the number of charge carriers and thus the electric resistivity is significantly increased to $7.6 \mu \Omega \mathrm{cm}[143]$ at $295 \mathrm{~K}$ compared to $\rho_{295 \mathrm{~K}, \mathrm{Cu}}=1.55 \mu \Omega \mathrm{cm}$ and $\rho_{295 \mathrm{~K}, \mathrm{Al}}=2.73 \mu \Omega \mathrm{cm}$. The strongly altered electronic and crystal structures determine the adsorption and the catalytic properties. Thus, it is necessary to keep the above mentioned differences between an intermetallic compound and an alloy in mind when looking at bi-metallic catalysts.

Staying with palladium, the direct consequences on the catalytic behavior upon compound formation can be demonstrated. While palladium possesses only a $\mathrm{CO}_{2}$ selectivity of $0.9 \%$ in methanol steam reforming, formation of the intermetallic compound $\mathrm{ZnPd}$ leads to 98\% $\mathrm{CO}_{2}$ selectivity [144]. In the following, the different roles played by intermetallic compounds in the steam reforming of methanol are discussed. Starting with the deliberate decomposition of intermetallic compounds to synthesize highly active catalysts and via the observation of intermetallic compounds forming during time on stream this section ends with the use of well-defined intermetallic systems to systematically develop an understanding of the underlying principles of the steam reforming of methanol. The following sections do not aim at a complete review of the existing literature, but at revealing the different ideas concerning intermetallic compounds and the steam reforming of methanol present in literature. 


\section{Catalysts derived by decomposition of intermetallic com- pounds}

Applying intermetallic compounds in methanol steam reforming is still a young scientific subject. The first appearance was in 1994 when Miyao et al. [145] used Al-Cu, $\mathrm{Cu}-\mathrm{Zn}$ and $\mathrm{Al}-\mathrm{Cu}-\mathrm{Zn}$ alloys, which contained intermetallic compounds such as $\mathrm{CuAl}_{2}, \mathrm{CuZn}$ and $\mathrm{Cu}_{5} \mathrm{Zn}_{8}$, as precursors to synthesize highly active Cu-based Raneytype catalysts. During leaching with aqueous $\mathrm{NaOH}$, the intermetallic compounds are decomposed and the observed catalytic properties can not be correlated to the crystal and/or electronic structure of the starting materials. Typically the leaching results in supported $\mathrm{Cu}$ particles with high surface area and thus higher activities than conventional $\mathrm{Cu}$-based systems.

Also single-phase intermetallic compounds like the wellinvestigated $\mathrm{CuAl}_{2}$ [142] and even quasicrystalline phases, i.e. ordered but non-periodic intermetallic compounds, have been used as precursors for Raney-type catalysts (Fig. 11). 


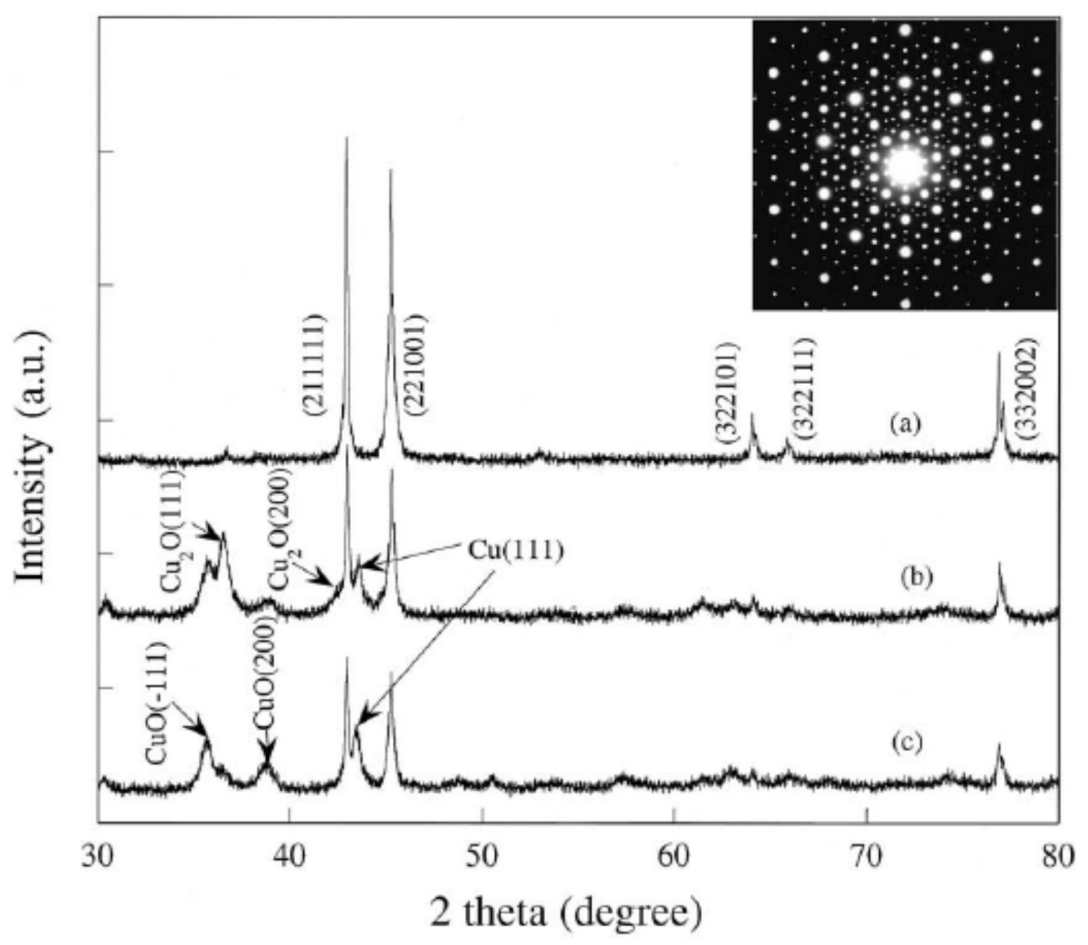

Figure 11: XRD of quasicrystalline $\mathrm{Al}_{63} \mathrm{Cu}_{25} \mathrm{Fe}_{12}$ (a), after leaching with 20 wt. $\% \mathrm{NaOH}$ at ambient temperature (b) and after use as methanol steam reforming catalyst (c). The inset shows an electron diffraction pattern of (a), proving the existence of the icosahedral quasicrystal. Reprinted from Appl. Catal. A 214, A.P. Tsai, T. Yoshimura, Highly active quasicrystalline Al-Cu-Fe catalyst for steam reforming of methanol, 237-241, Copyright 2001, with permission from Elsevier.

The group of Tsai leached powders of the quasicrystalline icosahedral i-Al-Cu-Fe phase, crystalline $\mathrm{Al}-\mathrm{Cu}-\mathrm{Fe}$ intermetallic compounds and $\mathrm{CuAl}_{2}$ with $\mathrm{NaOH}$ or $\mathrm{Na}_{2} \mathrm{CO}_{3}$ [22,146-148]. This leads to a preferential dissolution of aluminum from the surface of the particles, leaving the intermetallic core untouched. The surface after leaching consists of transition metal particles which are dispersed on an aluminum hydroxide layer. As in the case of the abovementioned materials, the $\mathrm{H}_{2}$ production rate increased to $235 \mathrm{~L} / \mathrm{kg}$, but the pres- 
ence of iron also leads to a higher stability of the $\mathrm{Cu}$ particles against sintering. Interestingly, leaching of the quasicrystalline phase resulted in higher activity and stability compared to the crystalline intermetallic precursors - a phenomenon not understood yet. Ma et al. modified the leaching solution for $\mathrm{CuAl}_{2}$ with $\mathrm{Na}_{2} \mathrm{CrO}_{4}$ and discovered that this increases the activity by a factor of two [23]. Using XPS, they could show, that the modification led to $\mathrm{Cr}_{2} \mathrm{O}_{3}$ promotion, which acts beneficial on the structural and catalytic properties. The presence of $\mathrm{Cr}_{2} \mathrm{O}_{3}$ results in higher BET surface areas due to higher porosity and smaller $\mathrm{Cu}$ particles. It was observed that $\mathrm{Cr}_{2} \mathrm{O}_{3}$ also increases the activity by itself, resulting in a higher activity compared to commercial copper chromite catalysts.

Another direction explored to generate high specific $\mathrm{Cu}$ surface areas is to oxidize intermetallic compounds or alloys prior to their use as catalysts. This approach is similar to a preparation of methanol synthesis catalysts which was developed in the 1970s by Wallace and Lambert $[149,150]$. Here the oxidation of $\mathrm{Cu}-R E(R E=$ rare earth element) intermetallic compounds like $\mathrm{CeCu}_{2}$ or $\mathrm{NdCu}_{5}$ in the $\mathrm{CO} / \mathrm{H}_{2}$ feed leads to finely dispersed $\mathrm{Cu}$ particles which are supported on the rare earth oxides (Fig. 12). 


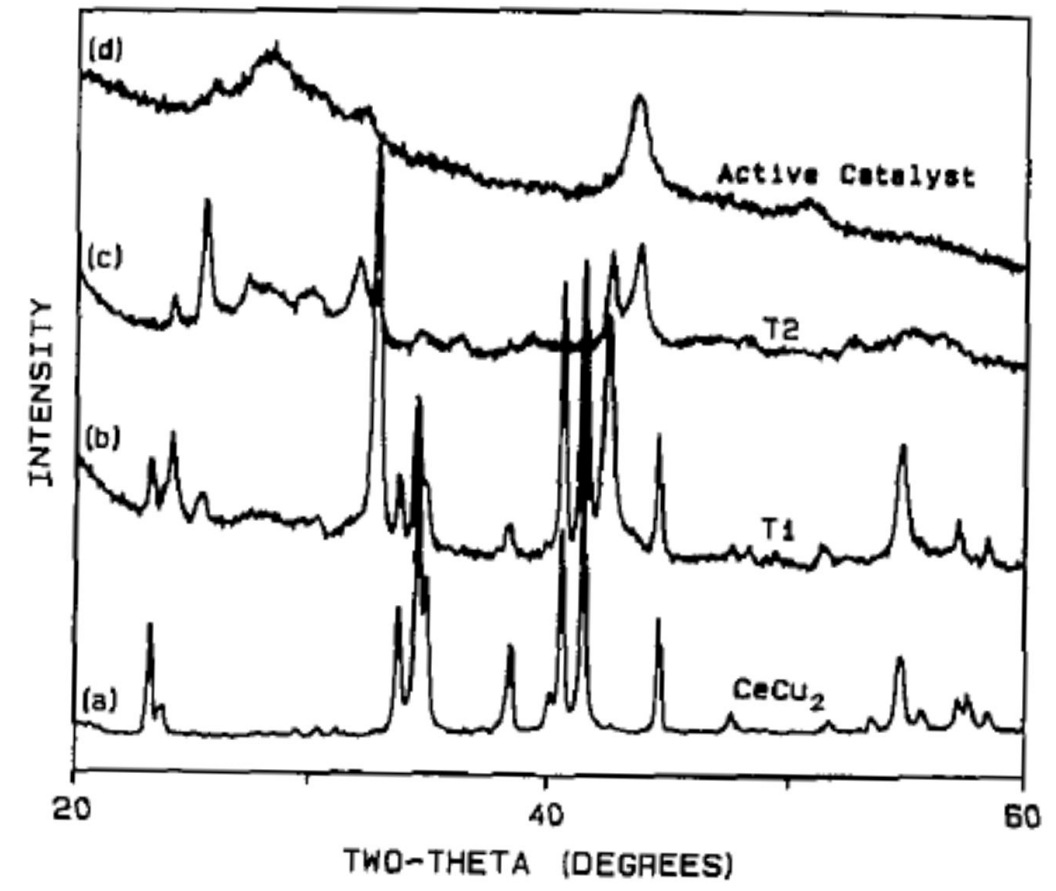

Figure 12: X-ray diffraction of $\mathrm{CeCu}_{2}$ in $\mathrm{He}$ (a) and during treatment in 15 bar $\mathrm{CO} / \mathrm{H}_{2}$ at $353 \mathrm{~K}$ (b) and $373 \mathrm{~K}(\mathrm{c}, \mathrm{d})$. The active state of the catalyst consists of $\mathrm{Cu}$ particles supported on $\mathrm{CeO}_{2}$, while $\mathrm{T} 1$ and $\mathrm{T} 2$ show the decomposition of the intermetallic compound during the treatment. Reprinted from J. Catal. 106, R.M. Nix, T. Rayment, R.M. Lambert, J.R. Jennings, G. Owen, An in situ X-ray diffraction study of the activation and performance of methanol synthesis catalysts derived from rare earth-copper alloys, 216-234, Copyright 1987, with permission from Elsevier.

Activation of $\mathrm{Ni}_{3} \mathrm{Al}$ in the methanol steam reforming feed leads to decomposition of the intermetallic compound to small Ni particles supported on oxidized/hydrolyzed aluminum [24]. While at a steam:carbon ratio of one both elements are oxidized, elemental $\mathrm{Ni}$ is preserved at a steam:carbon ratio of 0.1 . The observed catalytic properties of the $\mathrm{Ni}_{3} \mathrm{Al}$-derived catalysts correspond to Ni-based catalysts and show $\mathrm{CO}_{2}$-selectivities of only $10 \%$ since the main reaction - even under steam reforming conditions - is the decomposition of methanol. 
To obtain high specific transition metal surface areas, Takahashi et al. oxidized amorphous $\mathrm{Cu}-\mathrm{Zr}$ alloys with small contents of $\mathrm{Au}, \mathrm{Pd}$, $\mathrm{Pt}$ or $\mathrm{Rh}$ for $17 \mathrm{~h}$ in air at 570-587 K [25,151]. By subsequent reduction at $573 \mathrm{~K}$ in hydrogen, the desired supported transition metal catalysts were obtained. The most active catalysts were obtained from alloys with $\mathrm{Pt}$ and $\mathrm{Rh}$ contents around 1\%, while for $\mathrm{Au}$ the activity increased with increasing $\mathrm{Au}$ content. The selectivity towards $\mathrm{CO}_{2}$ of these catalysts was around $100 \%$ and it was concluded, that the main role of $\mathrm{Pt}, \mathrm{Rh}$ and $\mathrm{Au}$ is to increase the copper dispersion. The behavior of the $\mathrm{Pd}$ modified $\mathrm{Cu}-\mathrm{Zr}$ alloys differs significantly from the other alloys. While the activity is again increased, the selectivity to $\mathrm{CO}_{2}$ is only around $60 \%$. This can be attributed to the presence of elemental $\mathrm{Pd}$ which is an active catalyst for the decomposition of methanol to $\mathrm{CO}$.

Besides being decomposed, intermetallic compounds are important in other ways in the steam reforming of methanol: On the one hand, they are often observed after the use of oxide supported catalysts, which triggered research on their formation. On the other hand, unsupported intermetallic compounds are under investigation to reveal their part in the steam reforming of methanol. Research on these two topics is compiled below.

\section{Supported intermetallic compounds}

As seen above, intermetallic compounds can be changed by the reactive atmosphere applied - but also conventional supported (monometallic) catalysts can be very dynamic systems. This is for example 
expressed by deactivation due to sintering of the supported metal or the deposition of carbonaceous species.

Especially under reducing conditions (e.g. in the last step of the preparation) two other effects can be present. One is the so-called "strong metal-support interaction" (SMSI), which can be defined by three characteristics [152]: i) when reduced at low temperature, the catalyst shows a conventional chemical behavior, ii) hightemperature reduction strongly alters the chemisorption properties (SMSI state) and iii) the phenomenon is reversible by oxidation and mild reduction bringing the catalyst to state i). While in the first publication by Tauster the involvement of intermetallic compounds was suggested [153], the SMSI is today assigned to a covering of the metallic particles by a mobile and partly reduced support [155-156], a view that was also taken by Tauster in later publications [157]. The other phenomenon is the formation of intermetallic compounds by partial reduction of the (oxidic) support and subsequent reaction with the supported metal, for which we propose the term "reductive metal-support interaction" (RMSI). The formation of the intermetallic compounds has to be differentiated from the SMSI, since it is usually not reversible unless the catalysts are treated under very strong oxidizing conditions.

Instead of being formed before the reaction, intermetallic compounds can also be formed under reaction conditions by RMSI. Commonly, this process is not complete unless very high reduction temperatures are applied, where the necessary temperature depends on the combination of metal and support. Fig. 13 displays an exam- 
ple of the problem. Using only XRD, it is hard to identify the species present after reduction at low temperatures. The observed diffraction patterns could be due to partially reduced PdO, solid solutions of oxygen or hydrogen in $\mathrm{Pd}$ or intermetallic compounds. If the process is not complete, different potentially catalytically active species can be present and the resulting complex systems (different metallic species, support, numerous interfaces ...) hinder the determination of the catalytic properties of each of the components. While the RMSI is usually only observed in catalytic systems involving an easily reducible support (e.g. $\mathrm{ZnO}, \mathrm{Ge}_{2} \mathrm{O}_{3}, \mathrm{In}_{2} \mathrm{O}_{3}$ ) - unless very high temperatures are applied $[158,159]$ - the SMSI is not restricted to these systems and is also observed for $\mathrm{ZrO}_{2}$ and $\mathrm{Al}_{2} \mathrm{O}_{3}$ [157].

Research for alternative methanol steam reforming catalysts providing higher stability than the $\mathrm{Cu}$-based systems led to the investigation of Pd- and Pt-based catalysts. In the first publication by Iwasa et al. Pd and Pt on different supports were evaluated [160]. Normally, elemental Pd selectively catalyses the decomposition of methanol to $\mathrm{CO}$, even in the presence of water, resulting in high $\mathrm{CO}$ contents in the product [161]. Surprisingly, Iwasa et al. observed that in the case of $\mathrm{Pd} / \mathrm{ZnO}$ the $\mathrm{CO}_{2}$ selectivity improved drastically from 0 to $97 \%$ with prior reduction of the catalyst.

By comparison of $\mathrm{Pd} / \mathrm{ZnO}$ with $\mathrm{Pd} / \mathrm{SiO}_{2}$ and $\mathrm{Pd} / \mathrm{ZrO}_{2}$ they could show that by RMSI the intermetallic compound $\mathrm{ZnPd}$ is formed on $\mathrm{Pd} / \mathrm{ZnO}$, modifying strongly the catalytic selectivity of the $\mathrm{Pd} / \mathrm{ZnO}$ catalyst [144]. On the other hand, no intermetallic compound was formed on $\mathrm{Pd} / \mathrm{SiO}_{2}$ or $\mathrm{Pd} / \mathrm{ZrO}_{2}$ at comparable temperatures, resulting 
in low selectivities of $0.9 \%$ and $35 \%$ towards $\mathrm{CO}_{2}$, respectively (Fig. 13).
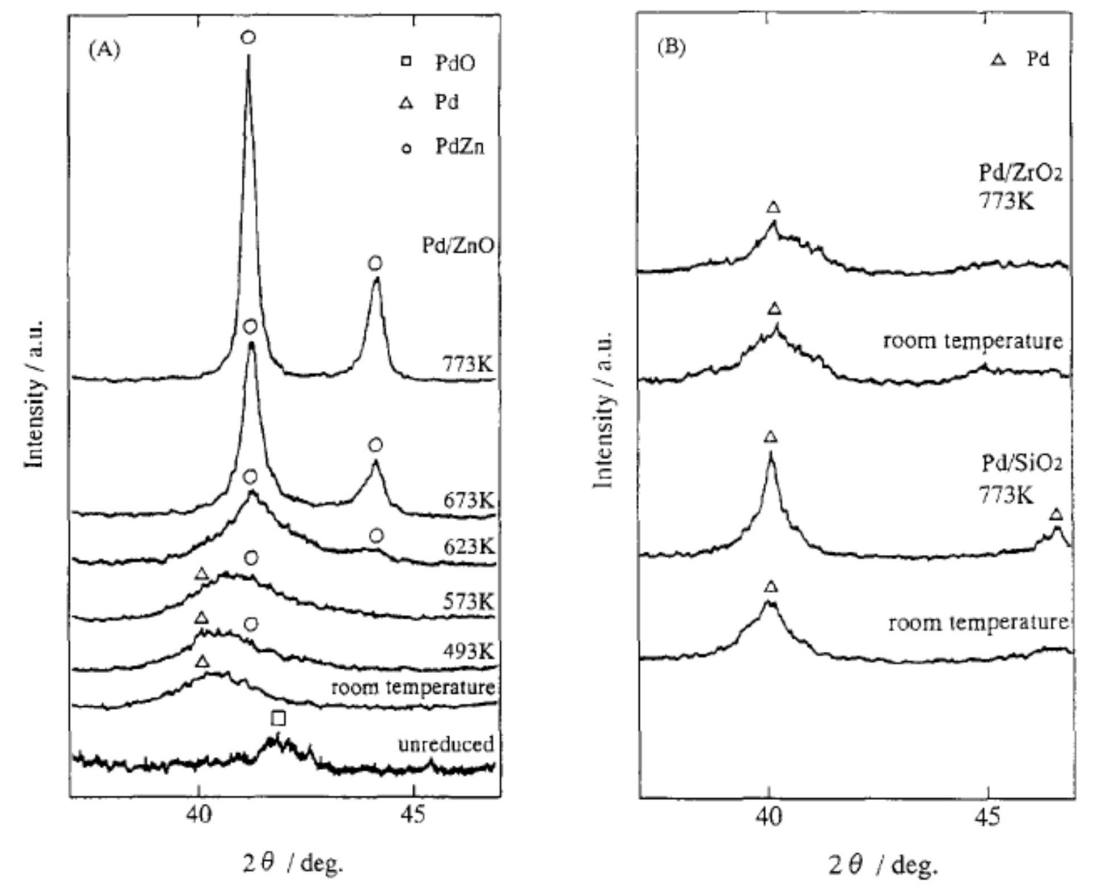

Figure 13: Powder X-ray diffraction of 10 wt.\% $\mathrm{Pd}$ on $\mathrm{ZnO}(\mathrm{A}), \mathrm{ZrO}_{2}$ and $\mathrm{SiO}_{2}$ (B), respectively. The temperatures at which the catalysts were reduced are given in the figure. Reprinted from Appl. Catal. A 125, N. Iwasa, S. Masuda, N. Ogawa, N. Takezawa, Steam reforming of methanol over Pd/ZnO: Effect of the formation of PdZn alloys upon the reaction, 145-157, Copyright 1995, with permission from Elsevier.

In addition to XRD, the compound formation was also detected by $\mathrm{X}$-ray photoelectron spectroscopy. The $\mathrm{Pd} 3 d_{5 / 2}$ signal for elemental palladium is observed at $335.1 \mathrm{eV}$. The reductive treatment of $\mathrm{Pd} / \mathrm{ZnO}$ at $673 \mathrm{~K}$ with hydrogen leads to a shift of $0.6 \mathrm{eV}$ of the $\mathrm{Pd}$ $3 d_{5 / 2}$ signal to higher binding energy.

The beneficial formation of $\mathrm{ZnPd}$ led to an increase of the conversion and selectivity from $33 \%$ and $62 \%$, respectively, for $\mathrm{Pd} / \mathrm{ZnO}$ catalysts reduced at $493 \mathrm{~K}$ to $58 \%$ and $98 \%$, respectively, after re- 
ductive treatment at $673 \mathrm{~K}$. For comparison, the conversion over $\mathrm{Pd} / \mathrm{SiO}_{2}$ was $10 \%$ with a selectivity of $0.9 \%$ and $\mathrm{Pd} / \mathrm{ZrO}_{2}$ showed a conversion of $87 \%$ and a selectivity of $20 \%$. It was suggested that the reason for the selectivity increase are the different reaction pathways for the decomposition of formaldehyde species on Pd and $\mathrm{ZnPd}$. While they are selectively decomposed to $\mathrm{CO}$ and $\mathrm{H}_{2}$ on elemental $\mathrm{Pd}$, the intermetallic compound $\mathrm{ZnPd}$ leads to an effective attack by water and subsequent decomposition to $\mathrm{CO}_{2}$ and $\mathrm{H}_{2}$ similar to the reaction path suggested for $\mathrm{Cu}$-based catalysts (Fig. 1).

These initial studies were followed by many others, making $\mathrm{ZnPd} / \mathrm{ZnO}$ the best investigated intermetallic system for the steam reforming of methanol. Special interest lies on how the intermetallic particles are formed and how the catalytic properties depend on the particle size and morphology. The formation of the intermetallic compound has been investigated by two approaches so far. Wang et al. studied $15.9 \% \mathrm{Pd} / \mathrm{ZnO}$ prepared by co-precipitation by temperature programmed reduction, desorption, electric conductivity and XRD $[162,163]$. The strong interaction between metallic palladium and the support leads to hydrogen spillover during reduction. This enables the reduction of the $\mathrm{ZnO}$ in the vicinity of the $\mathrm{Pd}$ particles and the formation of the intermetallic compound $\mathrm{ZnPd}$ at temperatures above $523 \mathrm{~K}$. The suggested reduction process follows the sequence $\mathrm{Pd} / \mathrm{ZnO} \rightarrow \mathrm{ZnPdO}_{1-x} / \mathrm{ZnO} \rightarrow \mathrm{ZnPd} / \mathrm{ZnO}$. For this catalyst, the best catalytic performance (41\% conversion, 94\% selectivity, hydrogen yield $0.65 \mathrm{molg}^{-1} \mathrm{~h}^{-1}$ at $523 \mathrm{~K}$ and a WHSV of $17.2 \mathrm{~h}^{-1}$ ) 
was obtained after reduction at $573 \mathrm{~K}$ for $1 \mathrm{~h}$ in pure hydrogen, which resulted in a crystallite size of 5-14 $\mathrm{nm}$.

A different approach was followed by Penner et al. [164], who synthesized well-defined thin film model systems by embedding epitaxially grown Pd-particles in an amorphous $\mathrm{ZnO}$ matrix which is mechanically stabilized by $\mathrm{SiO}_{2}$. The advantage of this approach is the possibility to perform in depth TEM characterization on these materials. The formation of well-ordered $\mathrm{ZnPd}$ was observed at temperatures as low as $473 \mathrm{~K}$ and it was stable up to $873 \mathrm{~K}$, where it partially decomposed into Pd-rich silicides. The epitaxial growth of the Pd particles causes their alike crystallographic orientation. This enabled the observation that the $\mathrm{ZnPd}$ intermetallic compound is formed by a topochemical reaction [165] starting at the surface of the Pd particles. Comparison of a similar $\mathrm{Pd} / \mathrm{SiO}_{2}$ thin film model revealed amorphisation of the Pd particles by reduction, most likely due to hydride formation. This clearly does not happen in the presence of $\mathrm{ZnO}$ as otherwise the crystallographic orientation between the particles would be lost. Most likely, hydrogen is activated on the Pd surface or a crystalline $\alpha$-Pd-hydride with low hydrogen content is formed. A low concentration of activated hydrogen is reasonable because the hydrogen is used up by the reduction of the $\mathrm{ZnO}$ in the vicinity of the Pd-particles immediately. Thus, the most likely reaction sequence is $\mathrm{Pd} / \mathrm{ZnO} \rightarrow$ " $\mathrm{PdH}_{x} " / \mathrm{ZnO} \rightarrow \mathrm{ZnPd} / \mathrm{ZnO}$, where " $\mathrm{PdH}_{x}$ " represents a crystalline Pd-hydride or activated hydrogen on the surface. Clarifying the intermediate in this reaction needs further investigation. 
The influence of the $\mathrm{ZnPd}$ particle size (2 to $34 \mathrm{~nm}$ mean diameter) on the catalytic performance was studied by Dagle et al. and Karim et al. $[166,167]$. They found, that the intermetallic compound $\mathrm{ZnPd}$ is already formed at the relatively mild reduction temperature of 523 $\mathrm{K}$. At these low temperatures, $\mathrm{ZnPd}$ and Pd co-exist on the support. By varying the reduction temperature, the $\mathrm{Pd} / \mathrm{ZnPd}$ ratio was changed, but no monotonic correlation between $\mathrm{ZnPd}$ content and the $\mathrm{CO}_{2}$ selectivity was observed. Instead, small particles showed $\mathrm{CO}_{2}$ selectivities of only $62 \%$ compared to $99 \%$ for the larger ones and highly selective catalysts could be obtained by elimination of the small and unselective particles of the intermetallic compound. The loss in selectivity can be explained with a strong activity increase of small $\mathrm{ZnPd}$ particles in the reverse water-gas-shift reaction, thus, the production of $\mathrm{CO}$ by converting $\mathrm{CO}_{2}$ and $\mathrm{H}_{2}$ [168,169]. Interestingly, large ZnPd particles (diameter of $34 \mathrm{~nm}$ ) show the same catalytic activity as small particles with $9 \mathrm{~nm}$ diameter. This might indicate that not only the intermetallic compound $\mathrm{ZnPd}$, but also the $\mathrm{ZnO}$ support play important roles during catalysis, e.g. by forming the catalytically active interface together.

The influence of $\mathrm{ZnO}$ on the catalytic properties has been studied in more detail by using catalytic systems consisting of $\mathrm{Pd}$ and $\mathrm{Zn}$ being present on an inert support like carbon or alumina. Suwa et al. compared the deactivation behavior of $\mathrm{ZnPd}-\mathrm{ZnO} / \mathrm{C}$ and $\mathrm{ZnPd} / \mathrm{ZnO}$ catalysts [170]. After $50 \mathrm{~h}$ time on stream, both catalysts showed deactivation from 70 to $60 \%$ and 70 to $40 \%$, respectively. XRD analysis revealed the presence of $\mathrm{Zn}_{4} \mathrm{CO}_{3}(\mathrm{OH})_{6}{ }^{*} \mathrm{H}_{2} \mathrm{O}$ on the $\mathrm{ZnPd} / \mathrm{ZnO}$ cata- 
lyst. It was concluded that the deactivation mechanism is due to $\mathrm{Zn}_{4} \mathrm{CO}_{3}(\mathrm{OH})_{6}{ }^{*} \mathrm{H}_{2} \mathrm{O}$ covering the intermetallic surface. The stronger deactivation of $\mathrm{ZnPd} / \mathrm{ZnO}$ compared to $\mathrm{ZnPd}-\mathrm{ZnO} / \mathrm{C}$ was explained by the higher amount on $\mathrm{ZnO}$ present on the former.

Another system on which the influence of $\mathrm{ZnO}$ has been studied is $\mathrm{Pd}-\mathrm{ZnO} / \mathrm{Al}_{2} \mathrm{O}_{3}$ [30]. A series of catalysts with different Pd loading and $\mathrm{Pd}: \mathrm{Zn}$ molar ratios was prepared, characterized and tested. The highest selectivity (98.6\%) and activity (80\% conversion at $523 \mathrm{~K}$ ) was revealed at a loading of $8.9 \% \mathrm{Pd}$ with a $\mathrm{Pd}: \mathrm{Zn}$ ratio of 0.38 . Doubling the ratio led to a six times higher $\mathrm{CO}$ content, whereas with half the ratio the $\mathrm{CO}$ content reached $1.7 \%$. By XRD, $\mathrm{ZnO}$ was observed at low $\mathrm{Pd}: \mathrm{Zn}$ ratios, while at high $\mathrm{Pd}: \mathrm{Zn}$ ratios elemental Pd was observed. This clearly shows, that an ideal Pd:Zn ratio exists. If not enough $\mathrm{Zn}$ is present, not all the $\mathrm{Pd}$ can be converted to $\mathrm{ZnPd}$, thus catalytically decomposing the methanol to $\mathrm{CO}$ and $\mathrm{H}_{2}$. Too high $\mathrm{Zn}$ contents on the other hand result in the formation of too much $\mathrm{ZnO}$, which leads to lower selectivities and deactivation.

$\mathrm{Pd} / \mathrm{ZnO}$ was also used in the oxidative steam reforming of methanol. Liu et al., who were the first to investigate this reaction/catalyst combination [171,172], studied in a series of publications the effect of the Pd-loading [173], the deactivation [174] and the influence of the presence of third metals [175]. In contrast to the steam reforming of methanol, the activity and selectivity increased with Pd loading, most probably due to the use of $\mathrm{ZnO}$ as support, thus not restricting the $\mathrm{Pd}: \mathrm{Zn}$ ratio. Testing the catalysts over $25 \mathrm{~h}$ resulted in a deacti- 
vation behavior superior to $\mathrm{Cu}$-based catalysts, but with increasing amounts of CO (up to 18\%) produced with time on stream (Fig. 14).

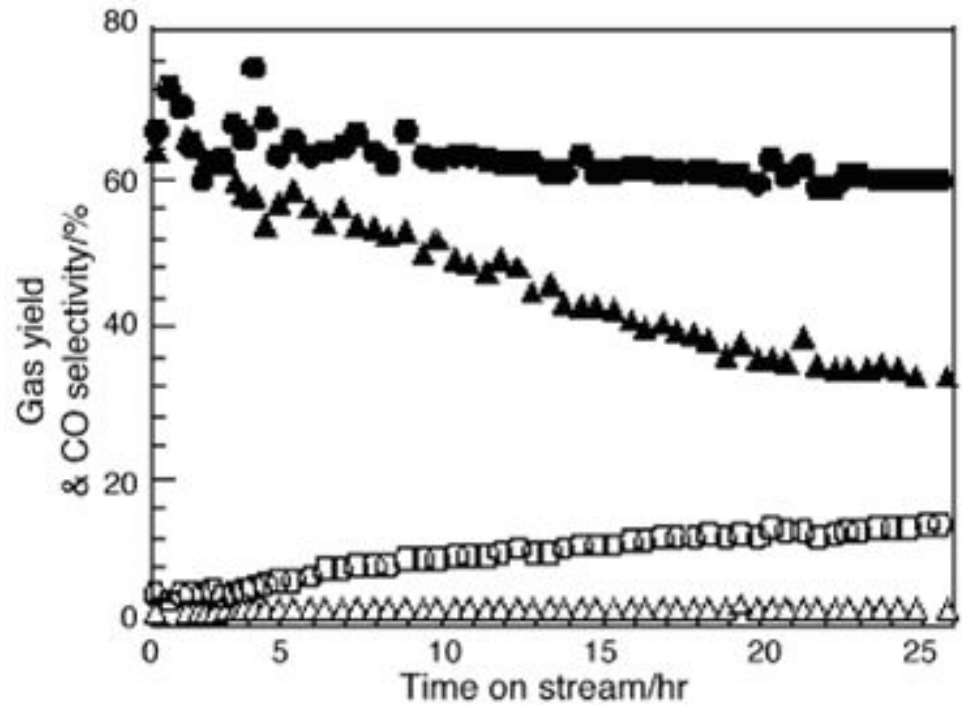

Fig. 14: Activity (solid symbols) and CO selectivity (open symbols) of $\mathrm{Pd} / \mathrm{ZnO}$ (circles) and a commercial Cu/ZnO catalyst (triangles). Reprinted from Appl. Catal. A 299, S. Liu, K.

Takajashi, K. Fuchigami, K. Uematsu, Hydrogen Production by Oxidative Methanol Reforming on Pd/ZnO: Catalyst Deactivation, 58-65, Copyright 2006, with permission from Elsevier.

By XPS investigations, it could be shown that the increasing $\mathrm{CO}$ content is due to a surface oxidation of the intermetallic compound $\mathrm{ZnPd}$ resulting in elemental palladium being present on the support, which leads to the decomposition of methanol. Modifying the $\mathrm{Pd} / \mathrm{ZnO}$ co-precipitated catalysts with transition metals resulted in higher $\mathrm{CO}$ contents except in the cases of small amounts of $\mathrm{Cr}, \mathrm{Fe}$ or $\mathrm{Cu}$, which increased the selectivity slightly. The promotional effect was assigned to the water gas shift activity of these transition metals. The intrinsically lower selectivity of unpromoted $\mathrm{Pd} / \mathrm{ZnO} / \mathrm{Al}_{2} \mathrm{O}_{3}$ was 
also observed for hydrotalcite derived catalysts, which showed $\mathrm{CO}_{2}$ selectivities of 74-89\% [176]. Thus it seems that using ZnPd in oxidative steam reforming is not a promising route to highly selective catalysts due to the decomposition of the selective intermetallic compound. In addition to methanol (oxidative) steam reforming, $\mathrm{ZnPd}$ has also been applied as catalyst for the partial oxidation of methanol [177-179] which is not in the focus of this chapter.

In summary, the catalytic system $\mathrm{Pd} / \mathrm{ZnO}$ is quite complex. The different catalytic activities of $\mathrm{ZnO}$, elemental $\mathrm{Pd}, \mathrm{ZnPd}$ and the resulting interfaces pose a hurdle for a knowledge-based development and the empirical data base is not sufficient yet to draw final conclusions about the ongoing processes and the involved species. Large differences exist between different $\mathrm{ZnPd} / \mathrm{ZnO}$ catalysts in the steam reforming of methanol (Table 1). These might be explained by different $\mathrm{Pd}: \mathrm{Zn}$ ratios and varying $\mathrm{ZnO}$ contents as well as by particle size effects at two stages. Firstly, the catalytic properties change with particle size as shown above. Secondly, the formation of Pdhydrides depends on the particle size [180-182] and if the formation of $\mathrm{ZnPd}$ is proceeding via a palladium hydride, size dependence during formation is expected. In consequence, each system and every preparation route involving $\mathrm{ZnPd}$ has its own ideal zinc content and reduction conditions which need to be explored and established. Leaving the system $\mathrm{Pd} / \mathrm{ZnO}$ and with it the intermetallic compound $\mathrm{ZnPd}$, a number of other systems involving intermetallic compounds have been investigated for the steam reforming of methanol, albeit not yet in such depth as the aforementioned $\mathrm{Pd} / \mathrm{ZnO}$. Iwasa et al. 
were the first to explore other transition metals supported on $\mathrm{ZnO}$ [27]. Amongst $\mathrm{Ni}, \mathrm{Co}$ and $\mathrm{Pt}$, only the latter formed an intermetallic compound ( $\mathrm{PtZn}$ ) during reduction. Compared to $\mathrm{Pt} / \mathrm{SiO}_{2}$ the $\mathrm{CO}_{2}$ selectivity was enhanced from $25.6 \%$ to $95.6 \%$. On the other hand, the Ni- and Co-based systems showed selectivities of 4.7 and $8.9 \%$, respectively. Testing $\mathrm{Pt}-\mathrm{Zn} / \mathrm{C}$, Ito et al. also observed a selectivity increase after formation of the intermetallic compound PtZn by reduction in $\mathrm{H}_{2}$ at $873 \mathrm{~K}$ [183]. The resulting selectivity increase from $48 \%$ for $\mathrm{Pt} / \mathrm{C}$ to $83 \%$ for $\mathrm{PtZn} / \mathrm{C}$ was not as high as for $\mathrm{PtZn} / \mathrm{ZnO}$, probably indicating an uncompleted transformation of $\mathrm{Pt}$.

In the next step, Iwasa et al. changed the support for the Pd- and Ptbased systems to $\mathrm{Ga}_{2} \mathrm{O}_{3}$ and $\mathrm{In}_{2} \mathrm{O}_{3}[26,28,184]$. After reduction, the intermetallic compounds $\mathrm{Pd}_{5} \mathrm{Ga}_{2}, \mathrm{PdGa}_{5}, \mathrm{Pd}_{0.52} \mathrm{In}_{0.48}$ (or PdIn), $\mathrm{Pt}_{5} \mathrm{Ga}_{3}, \mathrm{Pt}_{10.6} \mathrm{Ga}_{5.4}$ (or $\mathrm{Pt}_{5} \mathrm{Ga}_{3}$ ) and $\mathrm{PtIn}_{2}$ were formed as observed by TPD, XRD, XPS and AES. Using $\mathrm{Ga}_{2} \mathrm{O}_{3}$ as support resulted in a mixture of intermetallic compounds in contrast to $\mathrm{ZnO}$ or $\operatorname{In}_{2} \mathrm{O}_{3}$ supported catalysts. As in the case of $\mathrm{Pd} / \mathrm{ZnO}$, the formation of the intermetallic compounds led to a large increase in the observed $\mathrm{CO}_{2}$ selectivities. While the non-compound-forming systems $\mathrm{Pd} / \mathrm{SiO}_{2}$ and $\mathrm{Pt} / \mathrm{SiO}_{2}$ showed selectivities of 0 and $18.8 \%$, respectively, the Ga-Pd and Ga-Pt intermetallic compounds raised the selectivity to 94.6 and $75.5 \%$, respectively. In the case of the $\operatorname{In}_{2} \mathrm{O}_{3}$ supported catalysts, selectivities reached $95.5 \%$ for In-Pd intermetallic compounds and even $98.3 \%$ for In-Pt intermetallic compounds. Especially the latter nearly reaches that of $\mathrm{ZnPd} / \mathrm{ZnO}$ catalysts, which possess a selectivity of $99.2 \%$ under the same conditions. $\mathrm{PdIn} / \mathrm{Al}_{2} \mathrm{O}_{3}$ catalysts were 
applied in a microstructured reactor [29]. According to this study, $\mathrm{PdIn} / \mathrm{Al}_{2} \mathrm{O}_{3}$ seems to be a more dynamic system than $\mathrm{ZnPd} / \mathrm{ZnO}$. By undergoing a self-optimization by reduction in the feed and reaching a highly selective steady state, a pre-reduction is superfluous. To address the question why these intermetallic compounds behave so differently, the decomposition of formaldehyde, which is often claimed as intermediate in the steam reforming of methanol, was studied on elemental Pd and Pt catalysts as well as on the intermetallic compound catalysts. Here, a marked difference was observed: while the elements decomposed formaldehyde to $\mathrm{CO}$, the intermetallic compounds selectively produced $\mathrm{CO}_{2}[144,184]$. This difference, as well as the different selectivities in the steam reforming of methanol, was assigned to the distinguished adsorption of the aldehyde in the $\eta^{1}(\mathrm{O})$ structure on $\mathrm{Cu}$, and the $\eta^{2}(\mathrm{C}, \mathrm{O})$ structure on Pd, Pt and Ni. It was proposed that the very different catalytic properties of $\mathrm{ZnPd}$ and metallic Pd are due to the different structures of the $\mathrm{HCHO}$ intermediates on the metals. However, this view is not corroborated by theoretical calculations, which propose very similar adsorption geometries for the $\mathrm{HCHO}$ intermediate on $\mathrm{Cu}$ and $\mathrm{Pd}\left(\eta^{1}\right)$ but $\eta^{2}$ for $\mathrm{ZnPd}$ [185]. The support portfolio was enlarged by $\mathrm{GeO}_{2}$ (both the tetragonal and the hexagonal modification) and $\mathrm{SnO}_{2}$ [186]. Pd supported on these supports forms under reducing conditions $\mathrm{Pd}_{2} \mathrm{Ge}$ at $473-673 \mathrm{~K}$ and a mixture of $\mathrm{Pd}_{2} \mathrm{Sn}$ and $\mathrm{Pd}_{2} \mathrm{Sn}_{3}$ at $573 \mathrm{~K}$, respectively. In both cases, decomposition of methanol is the prevailing reaction, resulting in very low $\mathrm{CO}_{2}$ selectivities in the steam reforming of methanol. 
The formation of the Pd-based intermetallic compounds by reaction of the noble metal and the support was investigated - as in the case of $\mathrm{ZnPd}$ - in detail by thin film models by the group of Klötzer very recently. For these XRD, TEM and SEAD studies, small Pd particles were epitaxially grown on $\mathrm{NaCl}$ and this time covered with amorphous $\mathrm{Ga}_{2} \mathrm{O}_{3}, \mathrm{In}_{2} \mathrm{O}_{3}, \mathrm{GeO}_{2}$ or $\mathrm{SnO}_{2}[186,187]$. To mimic the conditions of the synthesis of the catalysts used above, the $\mathrm{Pd} / \mathrm{Ga}_{2} \mathrm{O}_{3}$ particles were first oxidized to $\mathrm{PdO}$ before being reduced at different temperatures in $\mathrm{H}_{2}$. Reducing the particles at $523 \mathrm{~K}$ resulted first in Pd particles, which subsequently were transformed to the intermetallic compound $\mathrm{Pd}_{5} \mathrm{Ga}_{2}$ (Fig. 15).
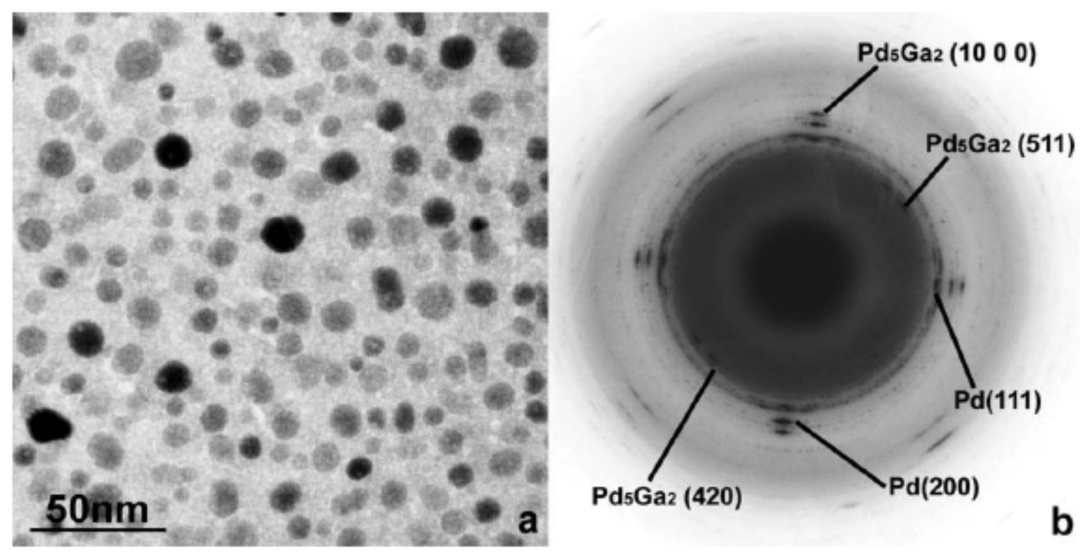

Figure 15: TEM image of $\mathrm{Pd} / \mathrm{Ga}_{2} \mathrm{O}_{3}$ thin film catalyst after reduction in 1 bar $\mathrm{H}_{2}$ (a). The corresponding SAED pattern is shown in (b). Reprinted from Appl. Catal. A 358, S. Penner, H. Lorenz, W. Jochum, M. Stöger-Pollach, D. Wang, C. Rameshan, B. Klötzer, $\mathrm{Pd} / \mathrm{Ga}_{2} \mathrm{O}_{3}$ methanol steam reforming catalysts: Part I. Morphology, composition and structural aspects, 193-202, Copyright 2009, with permission from Elsevier.

The transformation is not complete, even when the reduction temperature is raised to $773 \mathrm{~K}$. The remaining $\mathrm{Pd}$ is most probably located in the core of the particles, thus not taking part in the catalysis 
directly. Above $673 \mathrm{~K}$ pronounced sintering of the particles was observed in contrast to $\mathrm{ZnPd} / \mathrm{ZnO}$. The study was complemented by investigating an impregnated $\mathrm{Pd} / \beta-\mathrm{Ga}_{2} \mathrm{O}_{3}$ powder catalyst. In contrast to the thin film studies, the formation of the intermetallic compound $\mathrm{Pd}_{2} \mathrm{Ga}$ [188] was observed here by $\mathrm{XRD}$ at reduction temperatures above $573 \mathrm{~K}$. As in the thin films, elemental Pd is still present, even if the reduction is carried out at $773 \mathrm{~K}$. Above $923 \mathrm{~K}$, the $\mathrm{Pd}_{2} \mathrm{Ga}$ is transformed to the intermetallic compound PdGa by further reduction of the support. In difference to the work of Iwasa, the intermetallic compound $\mathrm{PdGa}_{5}$ was neither observed on the thin film nor on the powder catalyst after reduction.

In the case of the $\operatorname{In}_{2} \mathrm{O}_{3}$ supported catalyst also a thin film sample and a $\mathrm{Pd} / \mathrm{In}_{2} \mathrm{O}_{3}$ powder catalyst were used to investigate the compound formation [189]. Two main differences to the former investigated systems occur in the $\mathrm{Pd} / \mathrm{In}_{2} \mathrm{O}_{3}$ thin film samples: i) the deposited $\operatorname{In}_{2} \mathrm{O}_{3}$ is partly crystalline and not fully amorphous and ii) already during the deposition the formation of the intermetallic compound PdIn is observed. Reducing the thin film samples in $\mathrm{H}_{2}$ at $373 \mathrm{~K}$ resulted in higher PdIn contents and at $573 \mathrm{~K}$ the $\mathrm{In}_{2} \mathrm{O}_{3}$ film is fully crystallized. From the TEM investigation of the PdIn particles, it was concluded, that the topochemical reaction growth follows the scheme PdIn[001]||Pd[001] and PdIn[011]||Pd[011]. At $573 \mathrm{~K}$ all the Pd is transformed to PdIn and the orientation of the particles is lost due to the stability limit of the $\operatorname{In}_{2} \mathrm{O}_{3}$ in hydrogen atmosphere. Reduction of the powder catalyst resulted in the complete transformation of Pd to PdIn at $573 \mathrm{~K}$. As in the case of $\mathrm{Ga}_{2} \mathrm{O}_{3}$, higher tem- 
peratures lead to the formation of the main group metal-richer intermetallic compounds $\operatorname{Pd}_{2} \operatorname{In}_{3}(673 \mathrm{~K})$ and $\operatorname{PdIn}_{3}(773 \mathrm{~K})$.

Pd particles in a $\mathrm{GeO}_{2}$ matrix are converted to $\mathrm{Pd}_{2} \mathrm{Ge}$ at 473 to 573 $\mathrm{K}$ [186]. This transformation does not depend on the use of the $\mathrm{GeO}_{2}$ modifications if the particles are conventionally supported and furthermore, the only intermetallic compound observed on the amorphous thin films is $\mathrm{Pd}_{2} \mathrm{Ge}$. In contrast, the intermetallic compounds observed for $\mathrm{Pd}$ on $\mathrm{SnO}_{2}$ depend on whether a thin film sample with amorphous $\mathrm{SnO}_{2}$ or a conventionally supported system is reduced at $573 \mathrm{~K}$. In the first case, $\mathrm{Pd}_{2} \mathrm{Sn}$ and $\mathrm{Pd}_{3} \mathrm{Sn}_{2}$ are observed, while in the thin films the reduction yields $\mathrm{Pd}_{2} \mathrm{Sn}$ and $\mathrm{PdSn}$. Kamiuchi et al. investigated the interaction between the $\mathrm{Pd}$ particles and the $\mathrm{SnO}_{2}$ support [190]. After reduction at $673 \mathrm{~K}$ only the intermetallic compound $\mathrm{Pd}_{3} \mathrm{Sn}_{2}$ is formed and the particles are intruding into the support as revealed by subsequent TEM studies. During the short time of air-exposure, core-shell structures are formed by oxidation of the intermetallic tin on the surface. The core consists of the intermetallic compound $\mathrm{Pd}_{3} \mathrm{Sn}_{2}$ and the shell is an amorphous Sn-oxide corresponding to a SMSI state (see above). In contrast to the report by the group of Klötzer, $\mathrm{Pd}_{2} \mathrm{Sn}$ was only observed after re-oxidation of the sample in air at $673 \mathrm{~K}$ in the non-SMSI state.

Despite the thorough investigation of the formation processes of the intermetallic compounds, it is a disadvantage of all aforementioned systems that the intermetallic compound is at least mixed with the support and in most cases also with the corresponding noble metal in the elemental state. Sometimes even more than one intermetallic 
compound is present, bringing the complexity to an even higher level. In such systems, the number of possible catalytically active species hinders the assignment of the observed catalytic properties to a specific species and thus a knowledge-based development. The underlying processes might be complicated and most probably involve the support or the metal/support interfaces (at least in the case of $\mathrm{ZnPd} / \mathrm{ZnO}$, where this is indicated by the data available), but only reducing the complexity will allow to understand the role of the intermetallic compound. This approach can be followed either by theoretical calculations or by experiment and the progress achieved so far is summarized in the next section.

\section{Unsupported intermetallic compounds}

As seen in the large number of observations above, intermetallic compounds might play a pivotal role as catalysts for the steam reforming of methanol. However, the systems discussed so far do not allow an unambiguous correlation of the crystal and electronic structures of the intermetallic compounds and the observed catalytic properties for two reasons: i) the intermetallic compounds are not the only species present, and the support, e.g. $\mathrm{ZnO}$, might also influence the catalytic properties; ii) the stability of the compounds needs to be proven under reaction conditions. While the impact of the first point is quite obvious, the second one can be exemplified by the subsurface carbon phase formation of palladium during the gas-phase hydrogenation of alkynes [191-193]. Here, the alkyne is decomposed on the surface and part of the the carbon forms a metastable 
sub-surface Pd-C phase. The electronic structure of the material is changed significantly, which can be detected e.g. by XPS as a shift of the binding energy of the $\mathrm{Pd} 3 d_{5 / 2}$ signal of $0.6 \mathrm{eV}$. As soon as the hydrocarbon supply is stopped, the subsurface Pd-C decomposes by segregation of the carbon to the surface. Before and after the reaction, only elemental palladium is observed (with carbon deposits after reaction), while the catalytically active phase actually is palladium modified by the sub-surface carbon. Changes like this need to be detected and studied to allow valid correlations. Modifications by hydrocarbons might not play a major role in the steam reforming of methanol. But some intermetallic compounds are known to readily form hydrides in hydrogen containing atmospheres. As in the case of carbon-modified palladium, this leads to a strong alteration of the electronic and sometimes the crystal structure, as has e.g. been studied in the case of $\mathrm{LaNi}_{5}$ [194]. Besides hydride formation, decomposition of the intermetallic compounds can also occur as seen in the first section, demonstrating the need to prove the stability of the intermetallic compound in question under reaction conditions before correlating the electronic and crystal structure to the observed catalytic properties.

These requirements, i.e. to simplify the systems and prove their stability, can e.g. be fulfilled by performing experiments and quantum theoretical calculations on unsupported single-phase intermetallic compounds. Experimentally, this allows to detect changes to the materials much easier and, by proving the stability of the bulk and the surface, the resulting catalytic properties can be assigned directly to 
the intermetallic compound and, thus, to its crystal and electronic structure. Quantum chemical calculations can provide information about the surface, like adsorption properties and possible reaction pathways. In addition, bulk quantum chemical calculations of the electron localizability function allow studying the chemical bonding in real space [195-196]. These calculations give valuable insight and help to understand the stability under reaction conditions.

To investigate the intrinsic catalytic properties and stabilities experimentally, three different kinds of materials can be used. The first is the unsupported intermetallic compound, usually prepared by metallurgical synthesis or in nanoparticulate form. Large single crystals represent the second class of materials and so called surface alloys the third. While the first is best suited in crushed form for reactor studies, the other two represent materials for surface science studies. Using unsupported intermetallic compounds as powders in a reactor and as single crystals in UHV studies allows to bridge the experimental "materials gap". Ideally, the usually brittle single crystals can be comminuted after being studied in UHV and then be used for reactor studies. In addition, unsupported intermetallic compounds also allow closing the gap between quantum chemical calculations and experimental studies.

Nevertheless, there are material restrictions that one has to bear in mind. Surface alloys can be synthesized under UHV conditions by depositing e.g. $\mathrm{Zn}$ on a $\mathrm{Pd}$ single crystal and allow the $\mathrm{Zn}$ to react with the first few Pd layers. Complications arise, because the substrate and the surface alloy are usually electronic conducting materi- 
als and the electronic structures influence each other. The surface alloy - even if it has the same crystal structure as the corresponding bulk-phase - thus possesses a modified electronic structure, which might result in altered adsorption and catalytic properties. Similar considerations are true for intermetallic compounds in nanoparticulate form. Here, size-confinement effects can alter the electronic structure compared to the bulk. Since the influence is not known unless one compares bulk and nanoparticulate samples, nanoparticulate intermetallic compounds are not suitable to determine the intrinsic catalytic properties.

As could be shown in the case of Pd-Ga intermetallic compounds in the semi-hydrogenation of acetylene [137,198-200], it is important to perform the experimental studies on well characterized and single-phase materials, which can be obtained best by metallurgical synthesis routes. In contrast to alloys, intermetallic compounds are often brittle and allow easy comminution after synthesis, e.g. by grinding or milling. Changes of the materials by these treatments need to be investigated in order to find the best suited route to generate higher active surface, while keeping the intrinsic structure.

The most studied intermetallic compound with respect to methanol steam reforming is $\mathrm{ZnPd}$. These studies include the homogeneity range, chemical bonding and catalytic tests of the unsupported compound and extensive surface quantum chemical calculations. The range of existence of the tetragonal intermetallic compound $\mathrm{ZnPd}$ (CuAu type of structure, space group $P 4 / m m m, a=2.8931(1) \AA$ and $c=3.3426(2) \AA, c / a=1.16)$ reaches from $\mathrm{Zn}_{37.1(4)} \mathrm{Pd}_{62.9(4)}$ to 
$\mathrm{Zn}_{50.9(1)} \mathrm{Pd}_{49.1(1)}$ at $1173 \mathrm{~K}$ [139]. In contrast to the published binary phase diagram, the existence of the cubic high-temperature structure could not be confirmed experimentally in this reinvestigation. Quantum chemical tight-binding linear-muffin-tin-orbital (TB-LMTO) and full-potential local orbital (FPLO) calculations corroborated the experimental results and revealed a charge transfer from $\mathrm{Zn}$ to $\mathrm{Pd}$ of $0.4 \mathrm{e}^{-}$. Chemical bonding analysis by the electron localization indicator (ELI) revealed Pd-Pd interactions in the (001) plane as the driving force for the tetragonal distortion of $\mathrm{ZnPd}$. The electronic density of states (DOS) around the Fermi energy of ZnPd is very similar to the DOS of elemental copper and led to the suggestion that both should possess similar catalytic performance (Fig. 16) [31,201,202]. 


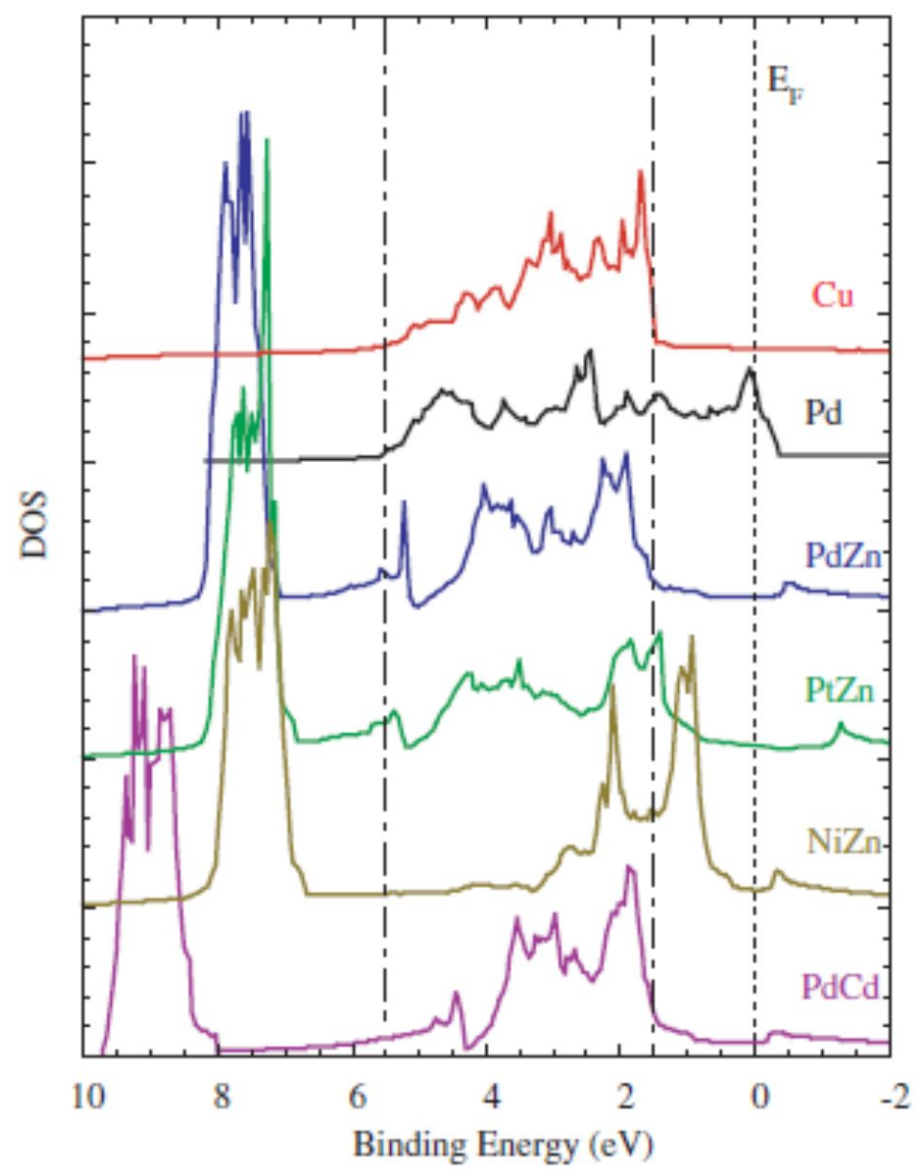

Figure 16: Electronic density of states for elemental $\mathrm{Cu}$ and $\mathrm{Pd}$ as well as for the intermetallic compounds ZnPd, PtZn, NiZn and PdCd. The dotted line represents the Fermi energy, while the two broken lines indicate the width of the $\mathrm{Cu} d$ states. Reprinted from J. Phys. Soc. Japan 73, A.P. Tsai, S. Kameoka, Y. Ishii, $\mathrm{PdZn}=\mathrm{Cu}$ : Can an intermetallic compound replace an element?, 3270-3273, Copyright 2004, with permission from the Physical Society of Japan.

Further quantum chemical calculations show [203] that segregation is unlikely in accordance with the chemical bonding situation as described above. Out of the low-indexed surfaces, the (111) and (100) surface are calculated to be the most stable ones [201,204]. To elucidate the reaction mechanism, the group of Rösch performed surface quantum chemical calculations on $\mathrm{ZnPd}$ (111), (100) and 
stepped (221) surfaces with Pd (221) $)^{\mathrm{Pd}}$ and Zn (221) ${ }^{\mathrm{Zn}}$, steps. Assuming the decomposition of methoxide $\left(\mathrm{CH}_{3} \mathrm{O}\right)$ as being the rate limiting step in the steam reforming of methanol over $\mathrm{Pd} / \mathrm{ZnO}$, density functional calculations of the $\mathrm{C}-\mathrm{O}$ and $\mathrm{C}-\mathrm{H}$ bond breaking were performed. On all surfaces, the activation barrier of the $\mathrm{C}-\mathrm{H}$ bond breaking is much lower than breaking the $\mathrm{C}-\mathrm{O}$ bond, suggesting the first step in the decomposition is the abstraction of an $\mathrm{H}$-atom. Nevertheless, calculations on defect-free $\mathrm{ZnPd}(111)$ and (100) surfaces revealed rather high activation barriers of $93 \mathrm{kJmol}^{-1}$ and $90 \mathrm{kJmol}^{-1}$ for the H-abstraction, respectively $[205,206]$. In contrast, the activation energy is lowered to around $50 \mathrm{kJmol}^{-1}$ in the case of the $\mathrm{ZnPd}$ $(221)^{\mathrm{Pd}}$ surface [207]. The reason for the lower activation energy is twofold: i) the reactant $\mathrm{CH}_{3} \mathrm{O}$ binds weaker to two Pd atoms of the step and ii) the resulting product $\mathrm{CH}_{2} \mathrm{O}$ is bound stronger. For the abstraction of the $\mathrm{H}$ atom, two possible mechanisms have been identified. The first proceeds by tilting of the $\mathrm{O}$-bound $\mathrm{CH}_{3} \mathrm{O}$ towards the terrace followed by $\mathrm{H}$-abstraction and possesses an activation energy of $49 \mathrm{kJmol}^{-1}$. In the second case, the C-O bond of the molecule is tilted towards the Pd-terminated step in the transition state and the $\mathrm{H}$-atom is placed in an edge-bridge site, resulting in an activation barrier of $53 \mathrm{kJmol}^{-1}$. Due to the large differences in activation energy of flat and stepped surfaces, it was concluded that the reaction is catalyzed by steps or other defects on the surface. A factor not considered in the calculations so far is the presence of $\mathrm{ZnO}$, which would result in a very complex system. Taking $\mathrm{ZnO}$ into account would be highly interesting, since the presence of $\mathrm{ZnO}$ could 
have an influence on the catalytic properties according to the experimental studies on supported systems.

The earliest work on Pd-Zn surface alloys in UHV was performed on $\mathrm{Pd}-\mathrm{Zn} / \mathrm{Ru}(001)$ and $\mathrm{Pd} / \mathrm{Zn}(0001)$ [208,209]. CO TDS on Pd$\mathrm{Zn} / \mathrm{Ru}(001)$ showed, that already very small amounts of $\mathrm{Zn}$ decrease the CO desorption energy dramatically. The full complexity of the $\mathrm{Pd}-\mathrm{Zn}$ surface alloy(s) has been investigated and is still under investigation by several groups applying a broad range of methods using $\mathrm{Zn} / \mathrm{Pd}(111)$ as common model system.

Deposition of $\mathrm{Zn}$ on $\mathrm{Pd}(111)$ below $300 \mathrm{~K}$ leads to elemental $\mathrm{Zn}$ multilayers, diffusion into the subsurface layers of $\mathrm{Pd}(111)$ starts at temperatures above $300 \mathrm{~K}$. Temperatures of $400-500 \mathrm{~K}$ lead to a metastable buckled surface alloy of several layers with a $p(2 \times 1)$ LEED pattern (surface alloy 1 - SA1) [202,210,211]. Impactcollision ion scattering spectroscopy (ICISS) shows, that the Zn atoms are sticking out of the surface with a 1:1 composition [202,210,212]. At temperatures above $550 \mathrm{~K}$, the $\mathrm{Zn}$ of the subsurface layers starts to diffuse into the bulk Pd, but the depletion is only slightly affecting the topmost layer [212]. At $623 \mathrm{~K}$ the diffusion of the $\mathrm{Zn}$ in subsurface layers has further progressed and a sub-surface Zn-diluted "monolayer" Pd-Zn surface alloy is obtained, which exhibits hardly any corrugation (SA2) [211-213]. The changes in the electronic structure by going from SA1 to SA2 are remarkable and result in a shift of the binding energy of the Pd $3 d_{5 / 2}$ XPS signal of 335.3 to $335.6 \mathrm{eV}$ and $335.9 \mathrm{eV}$ for the $1 \mathrm{ML}$ SA2 and a $3 \mathrm{ML}$ SA1, respectively (Fig. 17). 

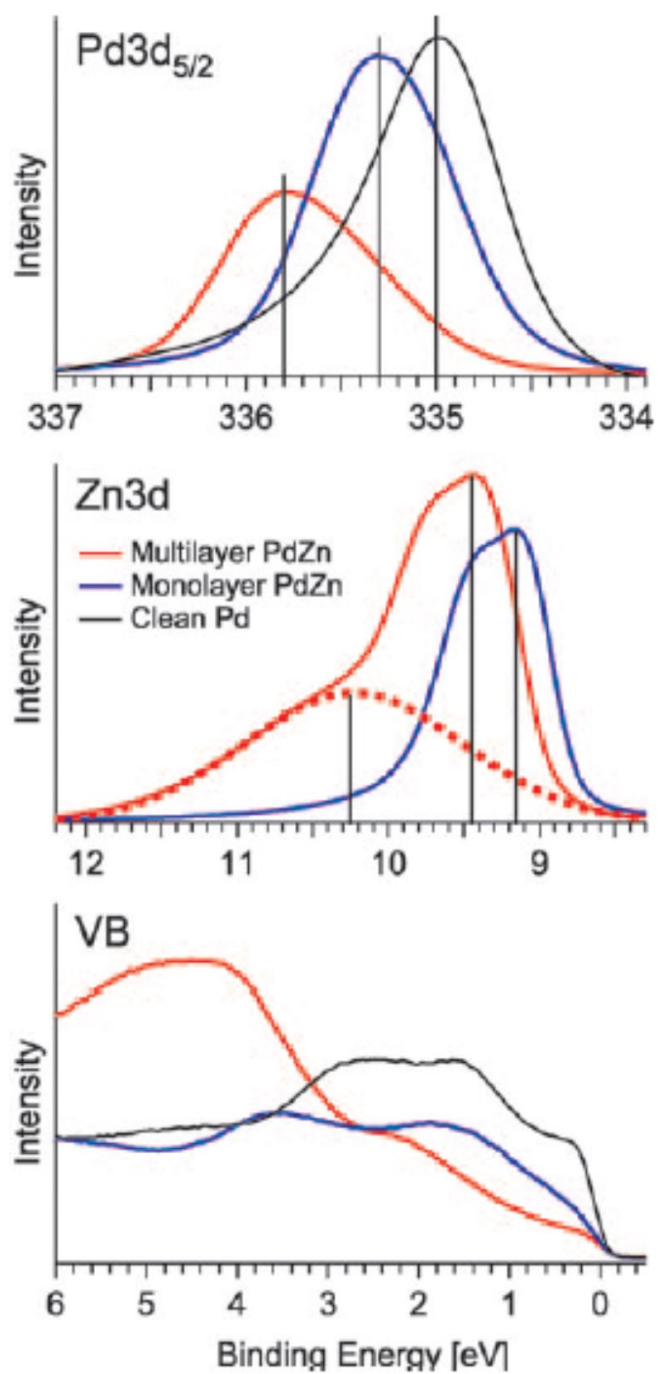

Figure 17: In situ X-ray photoelectron spectra ( $\mathrm{Pd} 3 d, \mathrm{Zn} 3 d$ and valence band (VB) regions) showing the large electronic differences between elemental Pd (black, ex situ), the monolayer surface alloy SA2 (blue) and the multilayer surface alloy SA1 (red). The red dashed line in the middle panel corresponds to an oxidized $\mathrm{ZnO}(\mathrm{H})$ component formed during the in situ spectra acquisition. Reprinted from Angew. Chem. Int. Ed. 49, C. Rameshan, W. Stadlmayr, C. Weilach, S. Penner, H. Lorenz, M. Hävecker, R. Blume, T. Rocha, D. Teschner, A. Knop-Gericke, R. Schlögl, N. Memmel, D. Zemlyanov, G. Rupprechter, B. Klötzer, Subsurface-Controlled $\mathrm{CO}_{2}$ Selectivity of PdZn Near-Surface Alloys in $\mathrm{H}_{2}$ Generation by Methanol Steam Reforming, 32243227, Copyright 2010, with permission from Wiley-VCH Verlag GmbH \& Co. KGaA. 
If the deposition is performed at $300 \mathrm{~K}, \mathrm{ZnPd}$ bilayer islands with a $\mathrm{Pd}: \mathrm{Zn}$ ratio of 1:1 are formed, which are shown to be more stable than monolayer islands by DFT calculations [213,214]. In contrast to SA1 and SA2, a $\mathrm{p}(2 \times 2)$ LEED pattern is reported if the layer is annealed at $520 \mathrm{~K}$ [215]. STM investigations revealed, that after deposition at $300 \mathrm{~K}$ three energetically identical $\mathrm{p}(2 \mathrm{x} 1)$ domains are formed (SA3) explaining the $\mathrm{p}(2 \times 2)$ LEED pattern $[213,216]$. As in the case of the multilayer alloy SA1 the surface of the bilayer islands of SA3 is not flat, but buckled with the $\mathrm{Zn}$ atoms sticking out $[210,213]$. If the whole surface is covered, additionally deposited $\mathrm{Zn}$ forms multilayers on top of SA3, which acts as a diffusion barrier at ambient temperature [213]. In difference to SA1, heating the $\mathrm{Zn}$ covered sample to more than $600 \mathrm{~K}$ leads to partial $\mathrm{Zn}$ desorption and partial bulk diffusion of the additional $\mathrm{Zn}$, before at $750 \mathrm{~K}$ the $\mathrm{Zn}$ of the SA3 starts to desorb [213]. As in the case of SA2, the buckling of the surface changes to Pd sticking out, as soon as the islands are reduced to one layer in thickness [213]. If the $\mathrm{Zn}$ deposition is carried out at $550 \mathrm{~K}$, the $\mathrm{p}(2 \mathrm{x} 1)$ LEED pattern characteristic for SA1 and SA2 is observed directly [202,217]. This indicates that at this temperature the ordered domains are much larger than after deposition at $300 \mathrm{~K}$ [217]. More complex surface structures have been observed after deposition of $>3 \mathrm{ML} \mathrm{Zn}$ at $750 \mathrm{~K}$. This procedure leads to a well ordered $\mathrm{ZnPd}$ surface alloy with a $(6 \times 4 \sqrt{3} / 3)$ rectangular LEED pattern (SA4) corresponding to an 8-fold superstructure compared to the bulk structure [215]. 
The fcc structure of elemental Pd and the CuAu type of structure of $\mathrm{ZnPd}$ are closely related. Replacing Pd with $\mathrm{Zn}$ in an ordered manner would result in a $c / a$ ratio of bulk $\mathrm{ZnPd}$ of 1.41. The experimentally determined ratio of 1.16 is significantly smaller, caused by the covalent bonding [137]. A bulk terminated (101) surface of $\mathrm{ZnPd}-$ corresponding to the $\mathrm{Pd}(111)$ surface - would result in a pseudo $\mathrm{p}(2 \times 1)$ LEED pattern with $a^{\prime}=5.2833 \AA$ and $b^{\prime}=2.6416 \AA$ instead of the ideal values of $a=5.4872 \AA$ and $b=2.7436 \AA$. Additionally, $\gamma^{\prime}$ would be $66.4^{\circ}$ instead of the ideal $60.0^{\circ}$ and the surface would be flat. However, no such deviations have been reported for the SA1 to SA4 yet. Since a comparison to the surface of bulk ZnPd is not possible yet, due to the challenges of growing such a crystal (> $1673 \mathrm{~K}$ are needed [218], which makes $\mathrm{Zn}$ very corrosive), the questions whether the underlying $\operatorname{Pd}(111)$ structure is causing a regular arrangement and the buckling, e.g. by modifying the electronic structure, can not be settled yet. The availability of a large $\mathrm{ZnPd}$ single crystal would also enable to settle the question how representative the results obtained for $\mathrm{Zn} / \mathrm{Pd}(111)$ are for other intermetallic surfaces, which are definitively present in supported $\mathrm{ZnPd} / \mathrm{ZnO}$ catalysts and in polycrystalline unsupported material.

What becomes clear by $\mathrm{CO}$ desorption measurements is the strong alteration of the chemical properties of the surface by $\mathrm{Zn}$ deposition and surface alloy formation. The desorption-maximum temperature is decreased by $220 \mathrm{~K}$ for SA1 and SA4 compared to a clean $\operatorname{Pd}(111)$ surface $[217,218]$. HREELS showed, that the decrease in desorption goes hand in hand with a change of $\mathrm{CO}$ being adsorbed in 
three-fold hollow and bridged sites to adsorption on-top for the surface alloy [217]. This has direct influences for the steam reforming of methanol, since not only the adsorption of $\mathrm{CO}$ is altered, but also the activity of methanol dehydrogenation is strongly decreased [216]. The dehydrogenation activity starts to decrease at as low $\mathrm{Zn}$ contents as $0.03 \mathrm{ML}$ and is nearly absent at coverages above $0.5 \mathrm{ML}$ [216]. This behavior has been assigned to the changes of the preferred adsorption sites for the intermediates $\mathrm{CH}_{3} \mathrm{O}$ and $\mathrm{CH}_{2} \mathrm{O}$ [216]. The former adsorbs on 3-fold hollow sites involving one or two $\mathrm{Zn}$ atoms, while the latter adsorbs in a bridging mode on a Pd-Zn dimer in such a way, that the $\mathrm{C}$ atom is bonded to the $\mathrm{Pd}$ and the $\mathrm{O}$ is bonded to the $\mathrm{Zn}$ atom.

Even more striking is the different catalytic behavior of SA1 and SA2 in the steam reforming of methanol, which has recently been investigated [211]. With the electronic structure, also the catalytic properties in the steam reforming of methanol change dramatically (Fig. 17). While the thin surface alloy SA2 shows only very low selectivity towards $\mathrm{CO}_{2}$ in the steam reforming of methanol, the multilayer surface alloy SA1 shows the expected high $\mathrm{CO}_{2}$ selectivity. A thickness of SA1 of as little as five layers is sufficient to induce these strong changes of the catalytic properties. However, until the real structure of the working supported or bulk intermetallic catalyst is revealed, UHV studies on the clean surface-alloy material are helpful for comparison to e.g. Pd, but the catalytically active supported or bulk material might be much more complex. 
Experimental catalytic studies on the bulk intermetallic compound $\mathrm{ZnPd}$ are very limited. Iwasa et al. synthesized Pd-Zn samples by heat treatment of physical mixtures of $\mathrm{Pd}$ and $\mathrm{Zn}$ at 220 to $673 \mathrm{~K}$ [219]. The resulting materials were investigated by XRD, which revealed the presence of $\mathrm{Pd}, \mathrm{Zn}, \mathrm{ZnPd}$ and/or $\mathrm{Zn}_{6.1} \mathrm{Pd}_{3.9}$ in the samples. Accordingly, the observed catalytic properties, e.g. the very low $\mathrm{CO}_{2}$-selectivity of only $87.5 \%$, can not be assigned to the intermetallic compound $\mathrm{ZnPd}$. Metallurgic single-phase samples of $\mathrm{ZnPd}$, PtZn, PdCd and NiZn were investigated by Tsai et al. [31]. The selection of the compounds was based on two considerations: i) they are all isostructural and ii) possess electronic structures which differ from $\mathrm{ZnPd}$ in the order PdCd $<\mathrm{PtZn}<\mathrm{NiZn}$. Fulfilling these criteria, the compounds allow investigating the electronic influence on the catalytic properties, since the geometric parameters are very similar by going from one compound to the other. The observed selectivities correspond to the expectations from the similarity of the electronic structures. At $553 \mathrm{~K} \mathrm{ZnPd}$ and PdCd show selectivities close to $100 \%$, PtZn possesses a $\mathrm{CO}_{2}$ selectivity of $45 \%$ and $\mathrm{NiZn}$ only $10 \%$. From these results, a strong influence of the electronic structure could be derived, provided the compound is stable in situ. The in situ stability of the unsupported intermetallic compounds NiZn, PtZn and ZnPd has been investigated recently by our group applying high-pressure X-ray photoelectron spectroscopy in reactive atmosphere. When the intermetallic compound $\mathrm{ZnPd}$ is heated in vacuum to $573 \mathrm{~K}$ and a 1:1 molar ratio $\mathrm{MeOH}: \mathrm{H}_{2} \mathrm{O}$ mixture is intro- 
duced subsequently, no changes occur in the $\mathrm{Zn} 3 d$ signal, as seen in the valence band spectra shown in Figure 18.

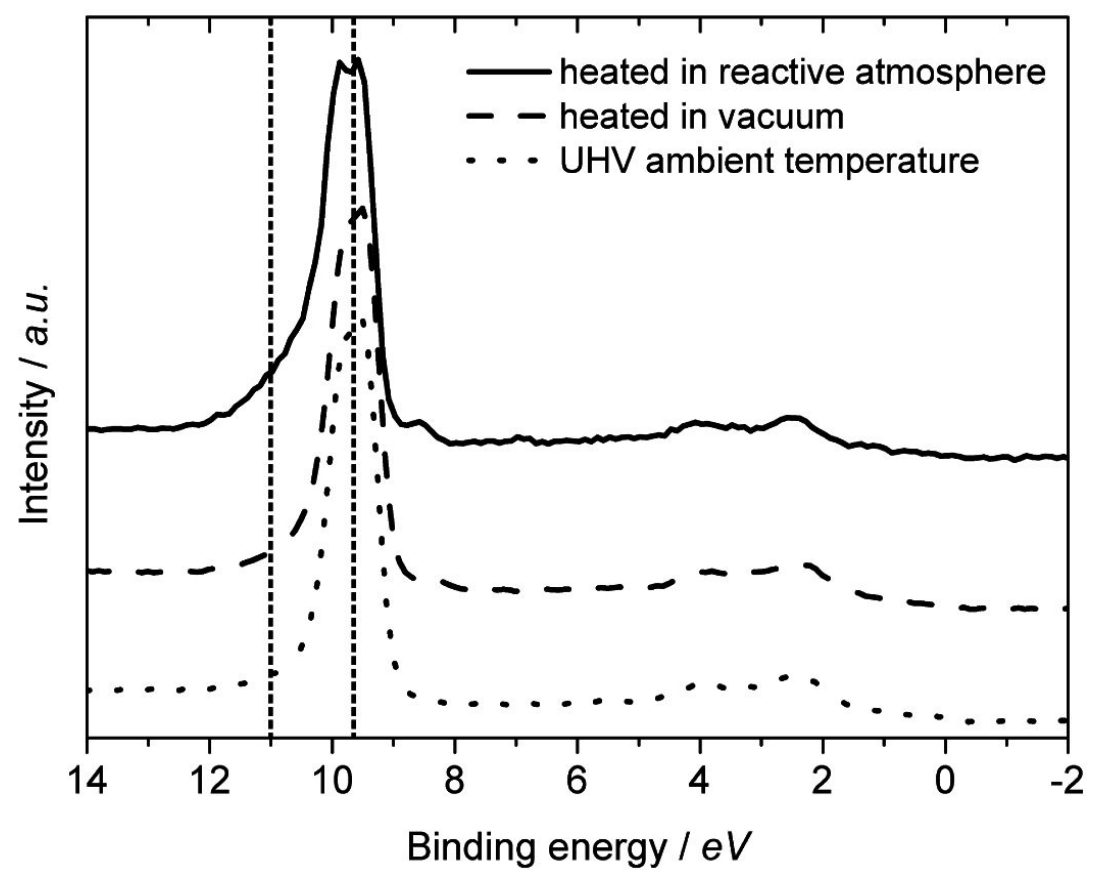

Figure 18: XPS valence band spectra of ZnPd: UHV conditions at ambient temperature (dotted line), in situ after heating to $573 \mathrm{~K}$ in UHV and subsequent switching to reactive atmosphere $(0.2$ mbar methanol $/ \mathrm{H}_{2} \mathrm{O}$ at a 1:1 ratio, dashed line) and in situ after heating to $573 \mathrm{~K}$ in reactive atmosphere (full line). Photon energy is set to $237 \mathrm{eV}$ for all spectra.

On the other hand, heating $\mathrm{ZnPd}$ in $\mathrm{MeOH} / \mathrm{H}_{2} \mathrm{O}$ atmosphere from RT to $573 \mathrm{~K}$ leads to the development of a shoulder at $11 \mathrm{eV}$ in the $\mathrm{Zn} 3 d$ signal, proving the formation of an oxidized $\mathrm{Zn}$ species on the surface (Fig. 18). For PtZn, very similar results are obtained. Interestingly, the intermetallic compound $\mathrm{ZnPd}$ without the oxidized $\mathrm{Zn}$ species on the surface is catalytically less active in reactor tests by a factor of more than 35 compared to the intermetallic compound heated in reactive atmosphere. These results show for the first time 
unambiguously, that $\mathrm{ZnPd}$ is not the only component of the active sites and that the oxidized Zn species plays a crucial role. On the other hand, too much $\mathrm{ZnO}$ is detrimental for the catalytic performance as proven by studies on supported catalysts.

The intermetallic compound NiZn undergoes severe surface changes under reaction conditions. The untreated surface in UHV consists of intermetallic $\mathrm{Ni}$ and $\mathrm{Zn}$, as well as oxidized $\mathrm{Zn}$ species as detected in the $\mathrm{Zn} 3 d$ region. As soon as the reactive gases are introduced to the XPS chamber $\left(0.2\right.$ mbar methanol $/ \mathrm{H}_{2} \mathrm{O}, 1: 1$ molar ratio, $\left.573 \mathrm{~K}\right)$, the surface of the compound changes dramatically (Fig. 19).

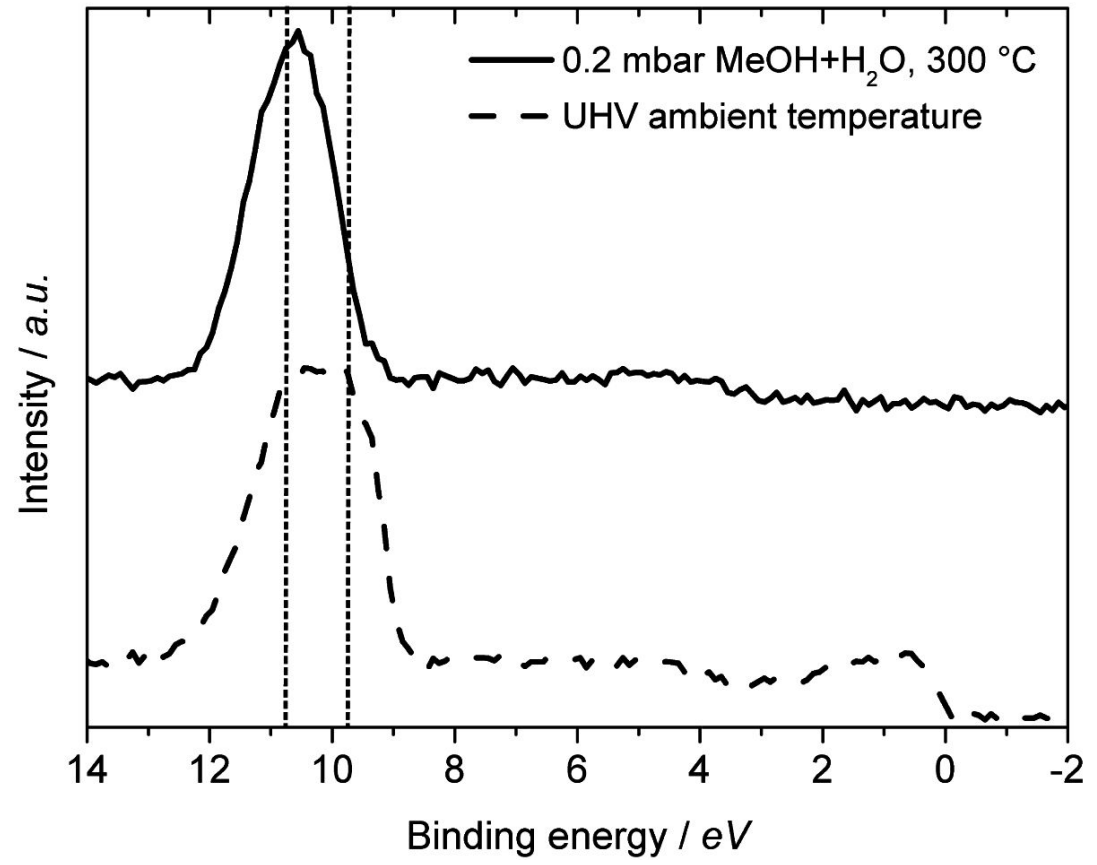

Figure 19: UHV (dashed) and in situ (full line) XPS valence band spectra of the intermetallic compound NiZn. Under UHV conditions, the metallic character is clearly seen at the Fermi energy. In reactive atmosphere, the $\mathrm{Zn}$ is completely oxidized and the density of states at the Fermi level is lost, indicating an oxidic overlayer. The incident photon energy is $301 \mathrm{eV}$ for both spectra. 
The intermetallic $\mathrm{Zn}$ on the surface is completely oxidized accompanied by a complete loss of the Ni core level signals in the most surface sensitive measurements. Thus, the methanol/ $\mathrm{H}_{2} \mathrm{O}$ mixture leads to segregation to and complete oxidation of the intermetallic $\mathrm{Zn}$ on the surface, forming a non-metallic and $\mathrm{Ni}$-free surface layer on the surface of the compound. In the case of the intermetallic compound NiZn, the observed catalytic properties can not be attributed to the compound itself, but to the generated decomposition products.

The results of these investigations show, that the intermetallic surface of these three compounds is altered under reaction conditions. It would also have been very hard to detect the changes on a supported catalyst due to the presence of large amounts of $\mathrm{ZnO}$, disguising the newly formed oxidized $\mathrm{Zn}$ species. The investigations demonstrate the advantage of using unsupported intermetallic compounds to study the role they (or their decomposition products) play in methanol steam reforming. These results also show that when investigating unsupported intermetallic compounds as catalysts, attention has to be paid to two issues: a) analysis is simpler on single phase samples and b) the in situ stability should be confirmed. Otherwise the identification of the intrinsic catalytic properties is hindered.

Robert Schlögl is greatly acknowledged for fruitful discussions and support. MB thanks the members of the Inorganic Chemistry Department of the Fritz Haber Institute for their help, support and discussions. MA thanks M. Friedrich for performing quantum chemical calculations and the Helmholtz Zentrum Berlin for providing BESSY beamtime 2009_1_80693 and continuing support during the XPS measurements. Networking within COST Action CM0904 "Network for Intermetallic Compounds as Catalysts in the Steam Reforming of Methanol" nurtured this publication. 


\section{References}

[1] Sato M (1998) R\&D activities in Japan on methanol synthesis from $\mathrm{CO}_{2}$ and $\mathrm{H}_{2}$. Catal. Surv. Jap. 2:175-184.

[2] Olah GA, Goeppert A, Surya Prakash GK (2006) Beyond Oil and Gas: The Methanol Economy. Wiley-VCH, Weinheim.

[3] Schlögl R (2010) The Role of Chemistry in the Energy Challenge. Chem. Sus. Chem. 3:209-222.

[4] Christiansen JA (1921) A reaction between methyl alcohol and water and some related reactions. J. Am. Chem. Soc. 43:1670-1672.

[5] Prigent M (1997) On board hydrogen generation for fuel cell powered electric cars - A review of various available techniques. Rev. Inst. Franc. Pét. 52:349-359.

[6] Navarro RM, Peña MA, Fierro JLG (2007) Hydrogen production reactions from carbon feedstocks: Fossils fuels and biomass. Chem. Rev. 107:3952-3991.

[7] Sá S, Silva H, Brandão L, Sousa JM, Mendes A (2010) Catalysts for methanol steam reforming-A review. Appl. Catal. B 99:43-57.

[8] De Wild PJ, Verhaak MJFM (2000) Catalytic production of hydrogen from methanol. Catal. Today 60:3-10.

[9] Joensen F, Rostrup-Nielsen JR (2002) Conversion of hydrocarbons and alcohols for fuel cells. J. Power Sources 105:195-201.

[10] Cheekatamarla PK, Finnerty CM (2006) Reforming catalysts for hydrogen generation in fuel cell applications. J. Power Sources 160:490-499.

[11] Palo DR, Dagle RA, Holladay JD (2007) Methanol steam reforming for hydrogen production. Chem. Rev. 107:3992-4021.

[12] Velu S, Suzuki K, Osaki T (1999) Oxidative steam reforming of methanol over CuZ$\mathrm{nAl}(\mathrm{Zr})$-oxide catalysts; a new and efficient method for the production of $\mathrm{CO}$-free hydrogen for fuel cells. Chem. Commun. 2341-2342.

[13] Lattner JR, Harold MP (2007) Autothermal reforming of methanol: Experiments and modeling. Catal. Today 130:78-89.

[14] Park ED, Lee D, Lee HC (2009) Recent progress in selective CO removal in a H-2-rich stream. Catal. Today 139:280-290.

[15] Agrell J, Birgersson H, Boutonnet M, Melián-Cabrera I, Navarro RM, Fierro JLG (2003) Production of hydrogen from methanol over $\mathrm{Cu} / \mathrm{ZnO}$ catalysts promoted by $\mathrm{ZrO}_{2}$ and $\mathrm{Al}_{2} \mathrm{O}_{3}$ J. Catal. 219:389-403.

[16] Turco M, Bagnasco G, Costantino U, Marmottini F, Montanari T, Ramis G, Busca G (2004) Production of hydrogen from oxidative steam reforming of methanol - II. Catalytic activity and reaction mechanism on $\mathrm{Cu} / \mathrm{ZnO} / \mathrm{Al}_{2} \mathrm{O}_{3}$ hydrotalcite-derived catalysts. J. Catal. 228:56-65.

[17] Kurr P, Kasatkin I, Girgsdies F, Trunschke A, Schlögl R, Ressler T (2008) Microstructural characterization of $\mathrm{Cu} / \mathrm{ZnO} / \mathrm{Al}_{2} \mathrm{O}_{3}$ catalysts for methanol steam reforming - A comparative study. Appl. Catal. A 348:153-164.

[18] Velu S, Suzuki K (2003) Selective production of hydrogen for fuel cells via oxidative steam reforming of methanol over CuZnAl oxide catalysts: effect of substitution of zirconium and cerium on the catalytic performance. Topics in Catal. 22:235-244.

[19] Purnama H, Girgsdies F, Ressler T, Schattka JH, Caruso RA, Schomäcker R, Schlögl R (2004) Activity and selectivity of a nanostructured $\mathrm{CuO} / \mathrm{ZrO}_{2}$ catalyst in the steam reforming of methanol. Catal. Lett. 94:61-68.

[20] Ritzkopf I, Vukojevic S, Weidenthaler C, Grunwaldt JD, Schüth F (2006) Decreased CO production in methanol steam reforming over $\mathrm{Cu} / \mathrm{ZrO}_{2}$ catalysts prepared by the microemulsion technique. Appl. Catal. A 302:215-223. 
[21] Liu Y, Hayakawa T, Suzuki K, Hamakawa S, Tsunody T, Ishii T, Kumagai M (2002) Highly active copper/ceria catalysts for steam reforming of methanol. Appl. Catal. A 223:137-145.

[22] Tsai AP, Yoshimura M (2001) Highly Active Quasicrystalline Al-Cu-Fe Catalyst for Steam Reforming of Methanol. Appl. Catal. A 214:237-241.

[23] Ma L, Gong B, Tran T, Wainwright MS (2000) $\mathrm{Cr}_{2} \mathrm{O}_{3}$ Promoted Skeletal Cu Catalysts for the Reactions of Methanol Steam Reforming and Water Gas Shift. Catal. Today 63:499505 .

[24] Jang JH, Xu Y, Chun DH, Demura M, Wee DM, Hirano T (2009) Effects of Steam Addition on the Spontaneous Activation in $\mathrm{Ni}_{3} \mathrm{Al}$ Foil Catalysts during Methanol Decomposition. J. Molec. Catal. A 307:21-28.

[25] Takahashi T, Inoue M, Kai T (2001) Effect of Metal Composition on Hydrogen Selectivity in Steam Reforming of Methanol over Catalysts Prepared from Amorphous Alloys. Appl. Catal. A 218:189-195.

[26] Iwasa N, Nomura W, Mayanagi T, Fujita SI, Arai M, Takezawa N (2004) Hydrogen Production by Steam Reforming of Methanol. J. Chem. Engin. Japan 37:286-293.

[27] Iwasa N, Masuda S, Takezawa, N (1995) Steam Reforming of Methanol over Ni, Co, Pd and Pt Supported on ZnO. React. Kinet. Catal. Lett. 55:349-353.

[28] Iwasa N, Mayanagi T, Ogawa N, Sakata K, Takezawa N (1998) New Catalytic Functions of Pd-Zn, Pd-Ga, Pd-In, Pt-Zn, Pt-Ga and Pt-In Alloys in the Conversion of Methanol. Catal. Lett. 54:119-123.

[29] Iwasa N, Nomura W, Mayanagi T, Fujita SI, Arai M, Takezawa N (2004) Hydrogen Production by Steam Reforming of Methanol. J. Chem. Engin. Japan 37:286-293.

[30] Xia G, Holladay JD, Dagle RA, Jones EO, Wang Y (2005) Development of Highly Active $\mathrm{Pd}-\mathrm{ZnO} / \mathrm{Al}_{2} \mathrm{O}_{3}$ Catalysts for Microscale Fuel Processor Applications. Chem. Engin. Technol. 28:515-519.

[31] Tsai AP, Kameoka S, Ishii Y (2004) PdZn = Cu: Can an Intermetallic Compound Replace an Element? J. Phys. Soc. Japan 73:3270-3273.

[32] Jiang CJ, Trimm DL, Wainwright MS, Cant NW (1993) Kinetic Mechanism for the Reaction Between Methanol and Water over A Cu-ZnO- $\mathrm{Al}_{2} \mathrm{O}_{3}$ Catalyst. Appl. Catal. A 97:145158.

[33] Takezawa N, Iwasa N (1997) Steam reforming and dehydrogenation of methanol: Difference in the catalytic functions of copper and group VIII metals. Catal. Today 36:45-56.

[34] Peppley BA, Amphlett JC, Kearns LM, Mann RF (1999) Methanol-steam reforming on $\mathrm{Cu} / \mathrm{ZnO} / \mathrm{Al}_{2} \mathrm{O}_{3}$ catalysts. Part 2. A comprehensive kinetic model. Appl. Catal. A 179:3149.

[35] Rozovskii AY, Lin GI (2003) Fundamentals of methanol synthesis and decomposition. Top. Catal. 22:137-150.

[36] Lee JK, Ko JB, Kim DH (2004) Methanol steam reforming over $\mathrm{Cu} / \mathrm{ZnO} / \mathrm{Al}_{2} \mathrm{O}_{3}$ catalyst: kinetics and effectiveness factor. Appl. Catal. A 278:25-35.

[37] Peppley BA, Amphlett JC, Kearns LM, Mann RF (2005) Methanol-steam reforming on $\mathrm{Cu} / \mathrm{ZnO} / \mathrm{Al} 2 \mathrm{O}$ 3. Part 1: the reaction network. Appl. Catal. A 179:21-29.

[38] Frank B, Jentoft FC, Soerijanto H, Kröhnert J, Schlögl R, Schomäcker R (2007) Steam reforming of methanol over copper-containing catalysts: Influence of support material on microkinetics. J. Catal. 246:177-192.

[39] Kasatkin I, Kurr P, Kniep B, Trunschke A, Schlögl R (2007) Role of Lattice Strain and Defects in Copper Particles on the Activity of $\mathrm{Cu} / \mathrm{ZnO} / \mathrm{Al}_{2} \mathrm{O}_{3}$ Catalysts for Methanol SynthesisAngew. Chem. 119:7465-7468.

[40] Chinchen GC, Hay CM, Vanderwell HD, Waugh KC (1987) The measurement of copper surface areas by reactive frontal chromatography. J. Catal. 103:79-86.

[41] Hinrichsen O, Genger T, Muhler M (2000) Chemisorption of $\mathrm{N}_{2} \mathrm{O}$ and $\mathrm{H}-2$ for the surface determination of copper catalysts. Chem. Eng. Technol. 11:956-959. 
[42] Naumann d'Alnoncourt R, Graf B, Xia X, Muhler M (2008) The back-titration of chemisorbed atomic oxygen on copper by carbon monoxide investigated by microcalorimetry and transient kinetics. J. Therm. Anal. Calor. 91:173-179.

[43] Behrens M, Furche A, Kasatkin I, Trunschke A, Busser W, Muhler M, Kniep B, Fischer R, Schlögl R (2010) The Potential of Microstructural Optimization in Metal/Oxide Catalysts: Higher Intrinsic Activity of Copper by Partial Embedding of Copper Nanoparticles. Chem. Cat. Chem. 2:816-818.

[44] Spencer MS (1999) The role of zinc oxide in $\mathrm{Cu} \mathrm{ZnO}$ catalysts for methanol synthesis and the water-gas shift reaction. Top. Catal. 8:259-266.

[45] Hansen JB, Højlund Nielsen PE (2008) Methanol Synthesis. In: Ertl G, Knözinger H, Schüth F, Weitkamp J (eds) Handbook of Heterogenous Catalysis, $2^{\text {nd }}$ edn. Wiley-VCH, Weinheim, 2920-2949.

[46] Naumann d'Alnoncourt R, Xia X, Strunk J, Löffler E, Hinrichsen O, Muhler M (2006) The influence of strongly reducing conditions on strong metal-support interactions in $\mathrm{Cu} / \mathrm{ZnO}$ catalysts used for methanol synthesis. Phys. Chem. Chem. Phys. 13:1525-1538.

[47] Grunwaldt JD, Molenbroek AM, Topsoe NY, Topsoe H, Clausen BS (2000) In situ investigations of structural changes in $\mathrm{Cu} / \mathrm{ZnO}$ catalysts. J. Catal. 194:452-460.

[48] Hansen PL, Wagner JB, Helveg S, Rostrup-Nielsen JR, Clausen BS, Topsoe H (2002) Atom-resolved imaging of dynamic shape changes in supported copper nanocrystals. Science 295:2053-2055.

[49] Spencer MS (1995) On the Activation-Energies of the Forward and Reverse Water-Gas Shift Reaction. Catal. Lett. 32:9-13.

[50] Twigg MV, Spencer MS (2003) Deactivation of copper metal catalysts for methanol decomposition, methanol steam reforming and methanol synthesis. Top. Catal. 22:191-203.

[51] Hughes R (1994) Deactivation of catalysts. Academic Press, New York.

[52] Kasatkin I et al., unpublished.

[53] Löffler DG, McDermott SD, Renn CN (2003) Activity and durability of water-gas shift catalysts used for the steam reforming of methanol. J. Power Sources 114:15-20.

[54] Thurgood CP, Amphlett JC, Mann RF, Peppley BA (2003) Deactivation of Cu/ $\mathrm{ZnO} / \mathrm{Al}_{2} \mathrm{O}_{3}$ catalyst: evolution of site concentrations with time. Topics Catal. 22:253-259.

[55] Agarwal V, Patel S, Pant KK (2005) H-2 production by steam reforming of methanol over $\mathrm{Cu} / \mathrm{ZnO} / \mathrm{Al}-2)$ catalysts: transient deactivation kinetics modeling. Appl. Catal. A 279:155164.

[56] Agrell J, Birgersson H, Boutonnet M (2002) Steam reforming of methanol over a $\mathrm{Cu} / \mathrm{ZnO} / \mathrm{Al}_{2} \mathrm{O}_{3}$ catalyst: a kinetic analysis and strategies for suppression of $\mathrm{CO}$ formation. J. Power Sources 106:249-257.

[57] Schimpf S, Muhler M (2009) Methanol Catalysts. In: Krijn de Jong (eds) Synthesis of Solid Catalysts. Wiley-VCH, Weinheim, 329-351.

[58] Bems B, Schur M, Dassenoy A, Junkes H, Herein D, Schlögl R (2003) Relations between synthesis and microstructural properties of copper/zinc hydroxycarbonates. Chem. Eur. J. 9:2039-2052.

[59] Baltes C, Vukojevic S, Schüth F (2008) Correlations between synthesis, precursor, and catalyst structure and activity of a large set of $\mathrm{CuO} / \mathrm{ZnO} / \mathrm{Al}_{2} \mathrm{O}_{3}$ catalysts for methanol synthesis. J. Catal. 258:334-344.

[60] Shen GC, Fujita SI, Takezawa N (1992) Preparation of Precursors for the Cu/ZnO Methanol Synthesis Catalysis by Coprecipitation Methods - Effects of The Preparation Conditions upon the Structures of the Precursors. J. Catal. 138:754-758.

[61] Günter MM, Ressler T, Bems B, Büscher C, Genger T, Hinrichsen O, Muhler M, Schlögl $\mathrm{R}$ (2001) Implication of the microstructure of binary $\mathrm{Cu} / \mathrm{ZnO}$ catalysts for their catalytic activity in methanol synthesis. Catal. Lett. 71:37-44.

[62] Waller D, Stirling D, Stone FS, Spencer MS (1989) Copper-Zinc Oxide Catalysts - Activity in Relation to Precursor Structure and Morphology. Faraday Dissuss. Chem. Soc. $87: 107-120$. 
[63] Li JL, Inui T (1996) Characterization of precursors of methanol synthesis catalysts, copper zinc aluminum oxides, precipitated at different $\mathrm{pHs}$ and temperatures. Appl. Cat. A 137:105-117.

[64] Whittle DM, Mirzaei AA, Hargreaves JSJ, Joyner RW, Kiely CJ, Taylor SH, Hutchings GJ (2002) Co-precipitated copper zinc oxide catalysts for ambient temperature carbon monoxide oxidation: effect of precipitate ageing on catalyst activity. Phys. Chem. Chem. Phys. 4:5915-5920.

[65] Kniep BL, Ressler T, Rabis A, Girgsdies F, Baenitz M, Steglich F, Schlögl R (2003) Ratioal Design of Nanostructured Copper-Zinc Oxide Catalysts for the Steam Reforming of Methanol. Angew. Chem Intern. Ed. 43:112-115.

[66] Behrens M, Brennecke D, Girgsdies F, Kißner S, Trunschke A, Nasrudin N, Zakaria S, Fadilah Idris N, Bee Abd Hamid S, Kniep B, Fischer R, Busser W, Muhler M, Schlögl R (2011) Understanding the complexity of a catalyst synthesis: Co-precipitation of mixed $\mathrm{Cu}, \mathrm{Zn}, \mathrm{Al}$ hydroxycarbonate precursors for $\mathrm{Cu} / \mathrm{ZnO} / \mathrm{Al}_{2} \mathrm{O}_{3}$ catalysts investigated by titration experiments. Appl. Catal A 392:93-102.

[67] Behrens $\mathrm{M}$ (2009) Meso- and nano-structuring of industrial $\mathrm{Cu} / \mathrm{ZnO} /\left(\mathrm{Al}_{2} \mathrm{O}_{3}\right)$ catalysts $\mathrm{J}$. Catal. 267:24-29.

[68] Schüth F, Hesse M, Unger KK (2008) Precipitation and Coprecipitation. In: Ertl G, Knözinger H, Schüth F, Weitkamp J (eds) Handbook of Heterogeneous Catalysis, $2^{\text {nd }}$ edn. Wiley-VCH, Weinheim, 100-119.

[69] Lok M. (2009) Coprecipitation. In: Krijn de Jong (eds) Synthesis of Solid Catalysts. Wiley-VCH, Weinheim, 135-151.

[70] Kniep BL, Girgsdies F, Ressler T (2005) Effect of precipitate aging on the microstructural characteristics of $\mathrm{Cu} / \mathrm{ZnO}$ catalysts for methanol steam reforming. J. Catal. 236:34-44.

[71] Millar GJ, Holm IH, Uwins PJR, Drennan J (1998) Characterization of precursors to methanol synthesis catalysts $\mathrm{Cu} / \mathrm{ZnO}$ system. J. Chem. Soc. Faraday Trans. 94:593-600.

[72] Behrens M, Girgsdies F, Trunschke A, Schlögl R (2009) Minerals as Model Compounds for $\mathrm{Cu} / \mathrm{ZnO}$ Catalyst Precursors: Structural and Thermal Properties and IR Spectra of Mineral and Synthetic (Zincian) Malachite, Rosasite and Aurichalcite and a Catalyst Precursor Mixture. Eur. J. Inorg. Chem. 10:1347-1357.

[73] Fujita S, Satriyo AM, Shen GC, Takezawa N (1995) Mechanism of the Formation of Precursors for the $\mathrm{Cu} / \mathrm{ZnO}$ Methanol Synthesis Catalysts by a Coprecipitation Method. Catalysis Letters 34:85-92.

[74] Behrens M, Girgsdies F (2010) Structural Effects of Cu/Zn Substitution in the MalachiteRosasite System. Z. Anorg. Allg. Chem. 636:919-927.

[75] Shen GC, Fujita S, Matsumoto S, Takezawa N (1997) Steam reforming of methanol on binary $\mathrm{Cu} / \mathrm{ZnO}$ catalysts: Effects of preparation condition upon precursors, surface structure and catalytic activity. J. Mol. Catal. A 124:123-136.

[76] Shishido T, Yamamoto Y, Morioka H, Takaki K, Takehira K (2004) Active Cu/ZnO and $\mathrm{Cu} / \mathrm{ZnO} / \mathrm{Al}_{2} \mathrm{O}_{3}$ catalysts prepared by homogeneous precipitation method in steam reforming of methanol. Appl. Catal. A 263:249-253.

[77] Shishido T, Yamamoto Y, Morioka H, Takehira K (2007) Production of hydrogen from methanol over $\mathrm{Cu} / \mathrm{ZnO}$ and $\mathrm{Cu} / \mathrm{ZnO} / \mathrm{Al}_{2} \mathrm{O}_{3}$ catalysts prepared by homogeneous precipitation: Steam reforming and oxidative steam reforming. J. Mol. Catal. A 268:185-194.

[78] Zhang XR, Wang LC, Yao CZ, Cao Y, Dai WL, He HY, Fan KN (2005) A highly efficient $\mathrm{Cu} / \mathrm{ZnO} / \mathrm{Al}_{2} \mathrm{O}_{3}$ catalyst via gel-coprecipitation of oxalate precursors for low-temperature steam reforming of methanol. Catal. Lett. 102:183-190.

[79] Wang LC, Liu YM, Chen M, Cao Y, He HY, Wu GS, Dai WL, Fan KN (2007) Production of hydrogen by steam reforming of methanol over $\mathrm{Cu} / \mathrm{ZnO}$ catalysts prepared via a practical soft reactive grinding route based on dry oxalate-precursor synthesis. J. Catal. 246:193204.

[80] Becker M, Naumann d'Alnoncourt R, Kähler K, Sekulic J, Fischer RA, Muhler M (2010) The Synthesis of Highly Loaded $\mathrm{Cu} / \mathrm{Al}_{2} \mathrm{O}_{3}$ and $\mathrm{Cu} / \mathrm{ZnO} / \mathrm{Al}_{2} \mathrm{O}_{3}$ Catalysts by the Two-Step 
CVD of $\mathrm{Cu}(\mathrm{II})$ diethylamino-2-propoxide in a Fluidized-Bed Reactor. Chem. Vap. Deposition 16:85-92.

[81] Kurtz M, Bauer N, Büscher C, Wilmer H, Hinrichsen O, Becker R, Rabe S, Merz K, Driess M, Fischer RA, Muhler M (2004) New synthetic routes to more active $\mathrm{Cu} / \mathrm{ZnO}$ catalysts used for methanol synthesis. Catal. Lett. 92:49-52.

[82] Omata K, Hashimoto M, Wanatabe Y, Umegaki T, Wagatsuma S, Ishiguro G, Yamada M, (2004) Optimization of $\mathrm{Cu}$ oxide catalyst for methanol synthesis under high $\mathrm{CO}_{2}$ partial pressure using combinatorial tools. Appl. Catal. A 262:207-214.

[83] Breen JP, Ross JRH (1999) Methanol reforming for fuel-cell applications: development of zirconia-containing $\mathrm{Cu}-\mathrm{Zn}-\mathrm{Al}$ catalysts. Catal. Today 51:521-533.

[84] Matsumura Y, Ishibe H (2009) Suppression of CO by-production in steam reforming of methanol by addition of zinc oxide to silica-supported copper catalyst. J. Catal. 268:282289.

[85] Yang HM, Liao PH (2007) Preparation and activity of Cu/ZnO-CNTs nano-catalyst on steam reforming of methanol. Appl. Catal. A 317:226-233.

[86] Kudo S, Maki T, Miura K, Mae K (2010) High porous carbon with Cu/ZnO nanoparticles made by the pyrolysis of carbon material as a catalyst for steam reforming of methanol and dimethyl ether. Carbon 48:1186-1195.

[87] Cavani F, Trifirò F, Vaccari A (1991) Hydrotalcite-type anionic clays: Preparation, properties and applications. Catal. Today 11:173-301.

[88] Takehira K, Shishido T (2007) Preparation of supported metal catalysts starting from hydrotalcites as the precursors and their improvements by adopting "memory effect". Catal. Surv. Asia 11:1-30.

[89] Tang Y, Liu Y, Zhu P, Xue Q, Chen L, Lu Y (2009) High-performance HTLcs-derived $\mathrm{CuZnAl}$ catalysts for hydrogen production via methanol steam reforming. Am. Inst. Chem. Eng. J. 55:1217-1228.

[90] Busca G, Constatino U, Marmottini F, Montanari T, Patrono P, Pinari F, Ramis G (2006) Methanol steam reforming over ex-hydrotalcite $\mathrm{Cu}-\mathrm{Zn}-\mathrm{Al}$ catalysts. Appl. Catal. A 310:70-78.

[91] Behrens M, Kasatkin I, Kühl S, Weinberg G (2010) Phase-Pure Cu,Zn,Al Hydrotalcitelike Materials as Precursors for Copper rich $\mathrm{Cu} / \mathrm{ZnO} / \mathrm{Al}_{2} \mathrm{O}_{3}$ Catalysts. Chem. Mater. 22:386-397.

[92] Kühl S, Friedrich M, Armbrüster M, Behrens M, unpublished.

[93] Turco M, Bagnasco G, Costantino U, Marmottini F, Montanari T, Ramis G, Busca G (2004) Production of hydrogen from oxidative steam reforming of methanol - I. Preparation and characterization of $\mathrm{Cu} / \mathrm{ZnO} / \mathrm{Al}_{2} \mathrm{O}_{3}$ catalysts from a hydrotalcite-like $\mathrm{LDH}$ precursor. J. Catal. 228:43-55.

[94] Turco M, Bagnasco G, Cammarano C, Senese P, Costantino U, Sisani M (2007) $\mathrm{Cu} / \mathrm{ZnO} / \mathrm{Al}_{2} \mathrm{O}_{3}$ catalysts for oxidative steam reforming of methanol: The role of $\mathrm{Cu}$ and the dispersing oxide matrix. Appl .Catal. B 77:46-57.

[95] Velu S, Suzuki K, Okazaki M, Kapoor MP, Osaki T, Ohashi F (2000) Oxidative steam reforming of methanol over $\mathrm{CuZnAl}(\mathrm{Zr})$-oxide catalysts for the selective production of hydrogen for fuel cells: Catalyst characterization and performance evaluation. J. Catal. 194:373-384.

[96] Velu S, Suzuki K, Kapoor MP, Ohashi F, Osaki T (2001) Selective production of hydrogen for fuel cells via oxidative steam reforming of methanol over $\mathrm{CuZnAl}(\mathrm{Zr})$-oxide catalysts. Appl. Catal. A 213:47-63.

[97] Velu S, Suzuki K, Gopinath CS, Yoshida H, Hattori T (2002) XPS, XANES and EXAFS investigations of $\mathrm{CuO} / \mathrm{ZnO} / \mathrm{Al}_{2} \mathrm{O}_{3} / \mathrm{ZrO}_{2}$ mixed oxide catalysts. Phys. Chem. Chem. Phys. 4:1990-1999.

[98] Breen JP, Ross JRH (1999) Methanol reforming for fuel-cell applications: development of zirconia-containing $\mathrm{Cu}-\mathrm{Zn}-\mathrm{Al}$ catalysts. Catal. Today 51:521-533. 
[99] Matsumura $Y$, Ishibe H (2009) High temperature steam reforming of methanol over $\mathrm{Cu} / \mathrm{ZnO} / \mathrm{ZrO}_{2}$ catalysts. Appl. Catal. B 91:524-532.

[100] Jones SD, Hagelin-Weaver HE (2009) Steam reforming of methanol over $\mathrm{CeO}_{2}$ - and $\mathrm{ZrO}_{2-}$ promoted $\mathrm{Cu}-\mathrm{ZnO}$ catalysts supported on nanoparticle $\mathrm{Al}_{2} \mathrm{O}_{3}$. Appl. Catal. B 90:195-204.

[101] Idem RO, Bakhshi NN (1996) Characterization studies of calcined, promoted and nonpromoted methanol-steam reforming catalysts. Can. J. Chem. Eng. 74:288-300.

[102] Lindström B, Pettersson LJ (2001) Hydrogen generation by steam reforming of methanol over copper-based catalysts for fuel cell applications. Int. J. Hydrogen Energy 26:923-933.

[103] Lindström B, Pettersson LJ, Menon PG (2002) Activity and characterization of Cu/Zn, $\mathrm{Cu} / \mathrm{Cr}$ and $\mathrm{Cu} / \mathrm{Zr}$ on gamma-alumina for methanol reforming for fuel cell vehicles. Appl. Catal. 234:111-125.

[104] Matsumura Y, Ishibe H (2009) Selective steam reforming of methanol over silicasupported copper catalyst prepared by sol-gel method. Appl. Catal. B 86:114-120.

[105] Kobayashi H, Takezawa N, Shimokawabe M, Takahashi K (1983) Preparation Of Copper Supported On Metal Oxides And Methanol Steam Reforming Reaction. Stud. Surf. Sci. Catal. 16:697-707.

[106] Takezawa N, Shimokawabe M, Hiramatsu H, Sugiura H, Asakawa T, Kobayashi H (1987) Steam Reforming of Methanol over $\mathrm{Cu} / \mathrm{ZrO}_{2}-$ Role of $\mathrm{ZrO}_{2}$ Support. React. Kinet. Catal. Lett. 33:191-196.

[107] Szizybalski A, Girgsdies F, Rabis A, Wang Y, Niederberger M, Ressler T (2005) In situ investigations of structure-activity relationships of a $\mathrm{Cu} / \mathrm{ZrO}_{2}$ catalyst for the steam reforming of methanol. J. Catal. 233:297-307.

[108] Oguchi $\mathrm{H}$, Kanai $\mathrm{H}$, Utani $\mathrm{K}$, Matsumura $\mathrm{Y}$, Imamura $\mathrm{S}$ (2005) $\mathrm{Cu}_{2} \mathrm{O}$ as active species in the steam reforming of methanol by $\mathrm{CuO} / \mathrm{ZrO}_{2}$ catalysts. Appl. Catal. A 293:64-70.

[109] Yao C, Wang L, Liu Y, Wu G, Cao Y, Dai W, He H, Fan K (2006) Effect of preparation method on the hydrogen production from methanol steam reforming over binary $\mathrm{Cu} / \mathrm{ZrO}_{2}$ catalysts. Appl. Catal. A 297:151-158.

[110] Wang LC, Liu Q, Chen M, Liu YM,. Cao Y, He HY, Fan KN (2007) Structural Evolution and Catalytic Properties of Nanostructured $\mathrm{Cu} / \mathrm{ZrO}_{2}$ Catalysts Prepared by Oxalate GelCoprecipitation Technique. J. Phys. Chem. C 111:16549-16557.

[111] Wu GS, Mao DS, Lu GZ, Cao Y, Fan KN (2009) The Role of the Promoters in Cu Based Catalysts for Methanol Steam Reforming. Catal. Lett. 130:177-184.

[112] Liu Y, Hayakawa T, Suzuki K, Hamakawa S (2001) Production of hydrogen by steam reforming of methanol over $\mathrm{Cu} / \mathrm{CeO}_{2}$ catalysts derived from $\mathrm{Ce}_{1-\mathrm{x}} \mathrm{Cu}_{\mathrm{x}} \mathrm{O}_{2-\mathrm{x}}$ precursors. Catal. Commun. 2:195-200.

[113] Liu Y, Hayakawa T, Tsunoda T, Suzuki K, Hamakawa S, Murato K, Shiozaki R, Ishii T, Kumagai M (2003) Steam reforming of methanol over $\mathrm{Cu} / \mathrm{CeO}_{2}$ catalysts studied in comparison with $\mathrm{Cu} / \mathrm{ZnO}$ and $\mathrm{Cu} / \mathrm{Zn}(\mathrm{Al}) \mathrm{O}$ catalysts. Top. Catal. 22:205-213.

[114] Mastalir A, Frank B, Szizybalski A, Soerijanto H, Deshpande A, Niederberger M, Schomäker R, Schlögl R, Ressler T (2005) Steam reforming of methanol over $\mathrm{Cu} / \mathrm{ZrO}_{2} / \mathrm{CeO}_{2}$ catalysts: a kinetic study. J. Catal. 230:464-475.

[115] Oguchi H, Nishiguchi T, Matsumoto T, Kanai H, Utani K, Matsumura Y, Imamura S (2005) Steam reforming of methanol over $\mathrm{Cu} / \mathrm{CeO}_{2} / \mathrm{ZrO}_{2}$ catalysts. Appl. Catal. A 281:6973.

[116] Huang TJ, Chen HM (2010) Hydrogen production via steam reforming of methanol over $\mathrm{Cu} /(\mathrm{Ce}, \mathrm{Gd}) \mathrm{O}_{2-\mathrm{x}}$ catalysts. Int. .J. Hydrogen Energy 35:6218-6226.

[117] Bhagwat M, Ramaswamy AV, Tyagi AK, Ramaswamy V (2003) Rietveld refinement study of nanocrystalline copper doped zirconia. Mate. Res. Bull. 38:1713-1724.

[118] Fierro G, Lo Jacono M, Inversi M, Porta P, Cioci F, Lavecchia R (1996) Study of the reducibility of copper in $\mathrm{CuO}---\mathrm{ZnO}$ catalysts by temperature-programmed reduction. Appl. Catal. A 137: 327-348. 
[119] Noei H, Qiu H, Wang Y, Löffler E, Wöll C, Muhler M (2008) The identification of hydroxyl groups on $\mathrm{ZnO}$ nanoparticles by infrared spectroscopy. Phys. Chem. Chem. Phys. 10:7092-7097.

[120] Günther MM, Ressler T, Jentoft RE, Bems B (2001) Redox Behavior of Copper Oxide/Zinc Oxide Catalysts in the Steam Reforming of Methanol Studied by in Situ X-Ray Diffraction and Absorption Spectroscopy. J. Catal. 203:133-149.

[121] Goddby BE, Pemberton JE (1988) XPS Characterization of a Commercial Cu/ $\mathrm{ZnO} / \mathrm{Al}_{2} \mathrm{O}_{3}$ Catalyst: Effects of Oxidation, Reduction, and the Steam Reformation of Methanol. Appl. Spectros. 42:754-760.

[122] Raimondi F, Geissler K, Wambach J, Wokaun A (2002) Hydrogen production by methanol reforming: post-reaction characterisation of a $\mathrm{Cu} / \mathrm{ZnO} / \mathrm{Al}_{2} \mathrm{O}_{3}$ catalyst by XPS and TPD. Appl. Surf. Sci. 189:59-71.

[123] Raimondi F, Schnyder B, Kötz R, Schelldorfer R, Jung T, Wambach J, Wokaun A (2003) Structural changes of model $\mathrm{Cu} / \mathrm{ZnO}$ catalysts during exposure to methanol reforming conditions. Surf. Sci. 532-535:383-389.

[124] Reitz TL, Lee PL, Czaplewski KF, Lang JC, Popp KE, Kung HH (2001) Time-resolved XANES investigation of $\mathrm{CuO} / \mathrm{ZnO}$ in the oxidative methanol reforming reaction. J. Catal. 199:193-201.

[125] Knop-Gericke A, Hävecker M, Schedel-Niedrig T, Schlögl R (2001) Characterisation of active phases of a copper catalyst for methanol oxidation under reaction conditions: an in situ X-ray absorption spectroscopy study in the soft energy range. Top. Catal. 15:27-34.

[126] Klier K (1982) Methanol Synthesis. Adv. Catal. 31:243-313.

[127] Costantino U, Marmottini F, Sisani M, Montanari T, Ramis G, Busca G, Turco M, Bagnsco G (2005) Cu-Zn-Al hydrotalcites as precursors of catalysts for the production of hydrogen from methanol. Solid State Ionics 176:2917-2922.

[128] Larrubia Vargas MA, Busca G, Costantino U, Marmottini F, Montatnari T, Patrono P, Pinzari F, Ramis G (2007) An IR study of methanol steam reforming over ex-hydrotalcite $\mathrm{Cu}-\mathrm{Zn}-\mathrm{Al}$ catalysts. J. Mol. Catal. A 266:188-197.

[129] Busca G, Montanari T, Resini C, Ramis G, Costantino U (2009) Hydrogen from alcohols: IR and flow reactor studies. Catal. Today 143:2-8.

[130] Sakong S, Groß A (2003) Dissociative adsorption of hydrogen on strained Cu surfaces. Surf. Sci. 525:107-118.

[131] Girgsdies F, Ressler T, Wild U, Wübben T, Balk TJ, Dehm G, Zhou L, Günther S, Arzt E, Imbihl R, Schlögl R (2005) Strained thin copper films as model catalysts in the materials gap. Catal. Lett. 102:91-97.

[132] Hammer B, Nørskov JK (1995) Electronic factors determining the reactivity of metal surfaces. Surf. Sci. 343:211-220.

[133] Frost JC (1988) Junction Effect Interactions in Methanol Synthesis Catalysts. Nature 334:577-580.

[134] Zhang XR, Wang LC, Cao Y, Dai WL, He HY, Fan KN (2005) A unique microwave effect on the microstructural modification of $\mathrm{Cu} / \mathrm{ZnO} / \mathrm{Al}_{2} \mathrm{O}_{3}$ catalysts for steam reforming of methanol. Chem. Commun. 4104-4106.

[135] Wang LC, Liu YM, Chen M, Cao Y, He HY, Wu GS, Dai WL, Fan KN (2007) Production of hydrogen by steam reforming of methanol over $\mathrm{Cu} / \mathrm{ZnO}$ catalysts prepared via a practical soft reactive grinding route based on dry oxalate-precursor synthesis. J. Catal. 246:193204.

[136] Holladay JD, Wang Y, Jones E (2004) Review of Developments in Portable Hydrogen Production Using Microreactor Technology. Chem. Rev. 104:4767-4790.

[137] Kovnir K, Armbrüster M, Teschner D, Venkov TV, Jentoft FC, Knop-Gericke A, Grin Yu, Schlögl R (2007) A New Approach to Well-Defined, Stable and Site-Isolated Catalysts. Sci. Technol. Adv. Mater. 8:420-427.

[138] Kohlmann H (2002) Metal Hydrides. In: Encyclopedia of Physical Science and Technology, $3^{\text {rd }}$ edn., Vol. 9, Academic Press, New York, 441-458. 
[139] Friedrich M, Ormeci A, Grin Yu, Armbrüster M (2010) PdZn or ZnPd: Charge Transfer and Pd-Pd Bonding as the Driving Force for the Tetragonal Distortion of the Cubic Crystal Structure, Z. Anorg. Allg. Chem. 636:1735-1739.

[140] Armbrüster M, Schnelle W, Schwarz U, Grin Yu (2007) Chemical Bonding in $\mathrm{TiSb}_{2}$ and $\mathrm{VSb}_{2}$ : A Quantum Chemical and Experimental Study. Inorg. Chem. 46:6319-6328.

[141] Armbrüster M, Schnelle W, Cardoso-Gil R, Grin Yu (2010) Chemical Bonding in the Isostructural Compounds $\mathrm{MnSn}_{2}, \mathrm{FeSn}_{2}$ and $\mathrm{CoSn}_{2}$. Chem. European J. 16:10357-10365.

[142] Grin Yu, Wagner FR, Armbrüster M, Kohout M, Leithe-Jasper A, Schwarz U, Wedig U, von Schnering HG (2006) $\mathrm{CuAl}_{2}$ Revisisted: Composition, Crystal Structure, Chemical Bonding, Compressibility and Raman Spectroscopy. J. Sol. State Chem. 179:1707-1719.

[143] Macchioni C, Rayne JA, Sen S, Bauer CL (1981) Low Temperature Resistivity of Thin Film and Bulk Samples of CuA12 and Cu9A14. Thin Solid Films 81:71-78.

[144] Iwasa N, Masuda S, Ogawa N, Takezawa N (1995) Steam Reforming of Methanol over $\mathrm{Pd} / \mathrm{ZnO}$ : Effects of the Formation of PdZn Alloys Upon the Reaction. Appl. Catal. A 125:145-157.

[145] Miyao K, Onodera H, Takezawa N (1994) Highly Active Copper Catalysts for Steam Reforming of Methanol. Catalysts Derived from $\mathrm{Cu} / \mathrm{Zn} / \mathrm{Al}$ Alloys. React. Kinet. Catal. Lett. $53: 379-383$

[146] Kameoka S, Tanabe T, Tsai AP (2004) Al-Cu-Fe Quasicrystals for Steam Reforming of Methanol: A New Form of Copper Catalyst. Catal. Today 93-95:23-26.

[147] Tanabe T, Kameoka S, Tsai AP (2006) A Novel Catalyst Fabricated from Al-Cu-Fe Quasicrystal for Steam Reforming of Methanol. Catal. Today 111:153-157.

[148] Yoshimura M, Tsai AP (2002) Quasicrystal Application on Catalyst. J. All. Compds. 342:451-454.

[149] Wallace WE, Elattar A, Imamura H, Craig RS, Moldovan, AG (1980) Intermetallic Compounds: Surface Chemistry, Hydrogen Absorption and Heterogeneous Catalysis. In: Wallace WE, Rao ECS (eds) Science and Technology of Rare Earth Materials, Academic Press, New York, 329-351.

[150] Nix RM, Rayment T, Lambert RM, Jennings JR, Owen G (1987) An in situ X-Ray Diffraction Study of the Activation and Performance of Methanol Synthesis Catalysts Derived from Rare-Earth-Copper Alloys. J. Catal. 106:216-234.

[151] Takahashi T, Kawabata M, Kai T, Kimura H, Inoue A (2006) Preparation of Highly Active Methanol Steam Reforming Catalysts from Glassy Cu-Zr Alloys with Small Amount of Noble Metals. Mater. Trans. 47:2081-2085.

[152] Bernal S, Calvino JJ, Cauqui MA, Gatica JM, Cartes CL, Omil JAP, Pintado JM (2003) Some Contributions of Electron Microscopy to the Characterisation of the Strong MetalSupport Interaction Effect. Catal. Today 77:385-406.

[153] Tauster SJ, Fung SC, Garten RL (1978) Strong Metal-Support Interactions. Group 8 Noble Metals Supported on $\mathrm{TiO}_{2}$. J. Am. Chem. Soc. 100:170-175.

[154] Knözinger H, Taglauer E (2008) Spreading and Wetting. In: Ertl G, Knözinger H, Schüth F, Weitkamp J (eds) Handbook of Heterogeneous Catalysis, $2^{\text {nd }}$ edn. Wiley-VCH, Weinheim, 555-571.

[155] Simoens AJ, Baker RTK, Dwyer DJ, Lund CRF, Madon RJ (1984) A Study of the NickelTitanium Oxide Interaction. J. Catal. 86:359-372.

[156] Centi G (2003) Metal-Support Interactions. In: Cornils B, Herrmann WA, Schlögl R, Wong CH (eds) Catalysis from A to Z, $2^{\text {nd }}$ edn. Wiley-VCH, Weinheim, 490-491.

[157] Tauster SJ (1987) Strong Metal-Support Interactions. Acc. Chem. Res. 20:389-394.

[158] Penner S, Wang, D, Su DS, Rupprechter G, Podloucky, R, Schlögl R, Hayek K(2003) Platinum nanocrystals supported by silica, ceria and alumina: metal-support interactions due to high-temperature reduction in hydrogen. Surf. Sci. 532-535: 276.

[159] Penner S, Wang D, Podloucky R, Schlögl R, Hayek K (2004) Rh and Pt nanoparticles supported by $\mathrm{CeO} 2$ : metal-support interaction upon high-temperature reduction observed by electron microscopy. Phys. Chem. Chem. Phys. 6: 5244. 
[160] Iwasa N, Kudo S, Takahashi H, Masuda S, Takezawa N (1993) Highly Selective Supported Pd Catalysts for Steam Reforming of Methanol. Catal. Lett. 19:211-216.

[161] Takezawa N, Iwasa N (1997) Steam Reforming and Dehydrogenation of Methanol: Difference in the Catalytic Functions of Copper and Group VIII Metals. Catal. Today 36:4556.

[162] Wang Y, Zhang J, Xu H (2006) Interaction Between Pd and ZnO during Reduction of $\mathrm{Pd} / \mathrm{ZnO}$ Catalyst for Steam Reforming of Methanol to Hydrogen. Chin. J. Catal. 27:217222.

[163] Wang Y, Zhang J, Xu H, Bai X (2007) Reduction of Pd/ZnO Catalyst and Its Catalytic Activity for Steam Reforming of Methanol. Chin. J. Catal. 28:234-238.

[164] Penner S, Jenewein B, Gabasch H, Klötzer B, Wang D, Knop-Gericke A, Schlögl R, Hayek K (2006) Growth and Structural Stability of Well-Ordered PdZn Alloy Nanoparticles. J. Catal. 241:14-19.

[165] Clark JB, Hastie JW, Kihlborg LHE, Metselaar R, Thackeray MM (1994) Definitions of Terms Relating to Phase Transitions of the Solid State. Pure \& App. Chem. 66:577-594.

[166] Dagle RA, Chin YH, Wang Y (2007) The Effects of PdZn Crystallite Size on Methanol Steam Reforming. Top. Catal. 46:358-362.

[167] Karim A, Conant T, Datye A. (2006) The Role of PdZn Alloy Formation and Particle Size on the Selectivity for Steam Reforming of Methanol. J. Catal. 243:420-427.

[168] Lebarbier V, Dagle R, Datye A, Wang Y (2010) The Effect of PdZn Particle Size on Reverse-Water-Gas-Shift Reaction. Appl. Catal. A 379:3-6.

[169] Bollmann L, Ratts JL, Joshi AM, Williams WD, Pazmino J, Joshi YV, Miller JT, Kropf AJ, Delgass WN, Ribeiro FH (2008) Effect of Zn Addition on the Water-Gas Shift Reaction over Supported Palladium Catalysts. J. Catal. 257:43-54.

[170] Suwa Y, Ito SI, Kameoka S, Tomishige K, Kunimori K (2004) Comparative Study Between $\mathrm{Zn}-\mathrm{Pd} / \mathrm{C}$ and $\mathrm{Pd} / \mathrm{ZnO}$ Catalysts for Steam Reforming of Methanol. Appl. Catal. A 267:9-16.

[171] Liu S, Takahashi K, Eguchi H, Uematsu K (2007) Hydrogen Production by Oxidative Methanol Reforming on Pd/ZnO: Catalyst Preparation and Supporting Materials. Catal. Today 129:287-292.

[172] Liu S, Takahashi K, Uematsu K, Ayabe M (2005) Hydrogen Production by Oxidative Methanol Reforming on Pd/ZnO. Appl. Catal. A 283:125-135.

[173] Liu S, Takahashi K, Ayabe M (2003) Hydrogen Production by Oxidative Methanol Reforming on Pd/ZnO Catalyst: Effect of Pd Loading. Catal. Today 87:247-253.

[174] Liu S, Takajashi K, Fuchigami K, Uematsu K (2006) Hydrogen Production by Oxidative Methanol Reforming on Pd/ZnO: Catalyst Deactivation. Appl. Catal. A 299:58-65.

[175] Liu S, Takahashi K, Uematsu K, Ayabe M (2004) Hydrogen Production by Oxidative Methanol Reforming on Pd/ZnO Catalyst: Effects of the Addition of a Third Metal Component. Appl. Catal. A 277:265-270.

[176] Lenarda M, Storaro L, Frattini R, Casagrande M, Marchiori M, Capannelli G, Uliana C, Ferrari F, Ganzerla R (2007) Oxidative Methanol Steam Reforming (OSRM) on a PdZnAl Hydrotalcite Derived Catalyst. Catal. Commun. 8:467-470.

[177] Cubeiro ML, Fierro JLG (1998) Partial Oxidation of Methanol Over Supported Palladium Catalysts. Appl. Catal. A 168:307-322.

[178] Cubeiro ML, Fierro JLG (1998) Selective Production of Hydrogen by Partial Oxidation of Methanol over ZnO-Supported Palladium Catalysts. J. Catal. 179:150-162.

[179] Agrell J, Germani G, Järås SG, Boutonnet M (2003) Production of Hydrogen by Partial Oxidation of Methanol Over ZnO-Supported Palladium Catalysts Prepared by Microemulsion Technique. Appl. Catal. A 242:233-245.

[180] Eastman JA, Thompson LJ, Kestel BJ (1993) Narrowing the Palladium-Hydrogen Miscibility Gap in Nanocrystalline Palladium. Phys. Rev. B 48:84-92.

[181] Yamauchi M, Ikeda R, Kitagawa H, Takata M (2008) Nanosize Effects on Hydrogen Storage in Palladium. J. Phys. Chem. C 112:3294-3299. 
[182] Tew MW, Miller JT, van Bokhoven JA (2009) Particle Size Effect of Hydride Formation and Surface Hydrogen Adsorption of Nanosized Palladium Catalysts: L3 Edge vs K Edge X-Ray Absorption Spectroscopy. J. Phys. Chem. C 113:15140-15147.

[183] Ito SI, Suwa Y, Kondo S, Kamoeka S, Timishige T, Kunimori K (2003) Steam Reforming of Methanol over Pt-Zn Alloy Catalyst Supported on Carbon Black. Catal. Commun. 4:499-503.

[184] Iwasa N, Takezawa N (2003) New Supported Pd and Pt Alloy Catalysts for Steam Reforming and Dehydrogenation of Methanol. Top. Catal. 22:215-224.

[185] Lim KH, Chen ZX, Neyman KM, Rösch N (2006) Comparative Theoretical Study of Formaldehyde Decomposition on PdZn, Cu, and Pd Surfaces. J. Phys. Chem. B 110:1489014897.

[186] Lorenz H, Zhao Q, Turner S, Lebedev BL, Van Tendeloo G, Klötzer B, Rameshan C, Pfaller K, Konzett J, Penner S (2010) Origin of Different Deactivation of $\mathrm{Pd} / \mathrm{SnO}_{2}$ and $\mathrm{Pd} / \mathrm{GeO}_{2}$ Catalysts in Methanol Dehydrogenation and Reforming: A Comparative Study. Appl. Catal. A 381:242-252.

[187] Penner S, Lorenz H, Jochum W, Stöger-Pollach M, Wang D, Rameshan C, Klötzer B (2009) $\mathrm{Pd} / \mathrm{Ga}_{2} \mathrm{O}_{3}$ Methanol Steam Reforming Catalysts: Part I. Morphology, Composition and Structural Aspects. Appl. Catal. A 358:193-202.

[188] Kovnir K, Schmidt M, Waurisch C, Armbrüster M, Prots Yu, Grin Yu (2008) Refinement of the Crystal Structure of Dipalladium Gallide, $\mathrm{Pd}_{2} \mathrm{Ga}$. Z. Kristallogr. - New Crystal Structures 223:7-8.

[189] Lorenz H, Turner S, Lebedev OI, Van Tendeloo G, Klötzer B, Rameshan C, Pfaller K, Penner S (2010) Pd- $\mathrm{In}_{2} \mathrm{O}_{3}$ Interaction Due to Reduction in Hydrogen: Consequences for Methanol Steam Reforming. Appl. Catal. A 374:180-188.

[190] Kamiuchi N, Muroyama H, Matsui T, Kikuchi R, Eguchi K (2010) Nano-Structural Changes of $\mathrm{SnO}_{2}$-Supported Palladium Catalysts by Redox Treatments. Appl. Catal. A 379:148-154.

[191] Teschner D, Borsodi J, Wootsch A, Révay Z, Hävecker M, Knop-Gericke A, Jackson SD, Schlögl R (2008) The Roles of Subsurface Carbon and Hydrogen in Palladium-Catalyzed Alkyne Hydrogenation. Science 320:86-89.

[192] Teschner D, Révay Z, Borsodi J, Hävecker M, Knop-Gericke A, Schlögl R, Milroy D, Jackson SD, Torres D, Sautet P (2008) Understanding Palladium Hydrogenation Catalysts: When the Nature of the Reactive Molecule Conrols the Nature of the Catalyst Active Phase. Angew. Chem. Int. Ed. 47:9274-9278.

[193] Seriani N, Mittendorfer F, Kresse G (2010) Carbon in Palladium Catalysts: A metastable Carbide. J. Chem. Phys. 132: 024711.

[194] Al Alam AF, Matar SF, Nakhl M, Quaini N (2009) Investigations of Changes in Crystal and Electronic Structures by Hydrogen within $\mathrm{LaNi}_{5}$ from First-Principles. Sol. State Sci. 11:1098-1106.

[195] Kohout M (2004) A Measure of Electron Localizability. Int. J. Quant. Chem. 97:651-658.

[196] Kohout M, Wagner FR, Grin Yu (2006) Atomic Shells from the Electron Localizability in Momentum Space. Int. J. Quant. Chem. 106:1499-1507.

[197] Kohout M (2007) Bonding Indicators from Electron Pair Density Functionals. Faraday Disc. 135:43-54.

[198] Kovnir K, Armbrüster M, Teschner D, Venkov TV, Szentmiklósi L, Jentoft FC, KnopGericke A, Grin Yu, Schlögl R (2009) In situ Surface Characterization of the Intermetallic Compound PdGa - A Highly Selective Hydrogenation Catalyst. Surf. Sci. 603:1784-1792.

[199] Osswald J, Giedigkeit R, Jentoft RE, Armbrüster M, Girgsdies F, Kovnir K, Grin Yu, Ressler T, Schlögl R (2008) Palladium Gallium Intermetallic Compounds for the Selective Hydrogenation of Acetylene. Part I: Preparation and Structural Investigation Under Reaction Conditions. J. Catal. 258:210-218.

[200] Osswald J, Kovnir K, Armbrüster M, Giedigkeit R, Jentoft RE, Wild U, Grin Yu, Schlögl R (2008) Palladium Gallium Intermetallic Compounds for the Selective Hydrogenation of 
Acetylene. Part II: Surface Characterization and Catalytic Performance. J. Catal. 258:219227.

[201] Chen ZX, Neyman KM, Gordienko AB, Rösch N (2003) Surface Structure and Stability of PdZn and PtZn Alloys: Density Functional Slab Model Studies. Phys. Rev. B 68:075417.

[202] Bayer A, Flechtner K, Denecke R, Steinrück HP, Neyman KM, Rösch N (2006) Electronic Properties of Thin Zn Layers on Pd(111) During Growth and Alloying. Surf. Sci. 600:7894.

[203] Chen ZX, Neyman KM, Rösch N (2004) Theoretical Study of Segregation of Zn and Pd in Pd-Zn Alloys. Surf. Sci. 548:291-300.

[204] Chen ZX, Neyman KM, Gordienko AB, Rösch N (2003) Surface Structure and Stability of PdZn and PtZn Alloys: Density-Functional Slab Model Studies. Phys. Rev. B 68:075417.

[205] Chen ZX, Neyman KM, Lim KH, Rösch N (2004) $\mathrm{CH}_{3} \mathrm{O}$ Decomposition on PdZn(111), $\mathrm{Pd}(111)$, and $\mathrm{Cu}(111)$. A Theoretical Study. Langmuir 20:8068-8077.

[206] Chen ZX, Lim KH, Neyman, KM, Rösch N (2004) Density Functional Study of Methoxide Decomposition on PdZn(100). Phys. Chem. Chem. Phys. 6:4499-4504.

[207] Chen ZX, Lim KH, Neyman KM, Rösch N (2005) Effect of Steps on the Decomposition of $\mathrm{CH}_{3} \mathrm{O}$ at PdZn Alloy Surfaces. J. Phys. Chem. B 109:4568-4574.

[208] Fasana A, Abbati I, Braicovich L (1982) Photoemission Evidence of Surface Segregation at Liquid-Nitrogen Temperature in Zn-Pd System. Phys. Rev. B 26:4749-4751.

[209] Rodriguez JA (1994) Interactions in Bimetallic Bonding: Electronic and Chemical Properties of PdZn Surfaces. J. Phys. Chem. 98:5758-5764.

[210] Stadlmayr W, Penner S, Klötzer B, Memmel N (2009) Growth, Thermal Stability and Structure of Ultrathin Zn-Layers on Pd(111). Surf. Sci. 603:251-255.

[211] Rameshan C, Stadlmayr W, Weilach C, Penner S, Lorenz H, Hävecker M, Blume R, Rocha T, Teschner D, Knop-Gericke A, Schlögl R, Memmel N, Zemlyanov D, Rupprechter G, Klötzer B (2010) Subsurface-Controlled $\mathrm{CO}_{2}$ Selectivity of PdZn Near-Surface Alloys in $\mathrm{H}_{2}$ Generation by Methanol Steam Reforming. Angew. Chem. Int. Ed. 49:3224-3227.

[212] Stadlmayr W, Rameshan C, Weilach C, Lorenz H, Hävecker M, Blume R, Rocha T, Teschner D, Knop-Gericke A, Zemlyanov D, Penner S, Schlögl R, Rupprechter G, Klötzer B, Memmel N (2010) Temperature-Induced Modifications of PdZn Layers on Pd(111). J. Phys. Chem. C 114:10850-10856.

[213] Weirum G, Kratzer M, Koch HP, Tamtögl A, Killmann J, Bako I, Winkler A, Surnev S, Netzer FP, Schennach R (2009) Growth and Desorption Kinetics of Ultrathin Zn Layers on Pd(111). J. Phys. Chem. C 113:9788-9796.

[214] Koch HP, Bako I, Weirum G, Kratzer M, Schennach R (2010) A Theoretical Study of Zn Adsorption and Desorption on a Pd(111) Substrate. Surf. Sci. 604:926-931.

[215] Gabasch H, Knop-Gericke A, Schlögl R, Penner S, Jenewein B, Hayek K, Klötzer B (2006) Zn Adsorption on Pd(111): ZnO and PdZn Alloy Formation. J. Phys. Chem. B 110:11391-11398.

[216] Jeroro E, Vohs JM (2008) Zn Modification of the reactivity of Pd(111) Toward Methanol and Formaldehyde. J. Am. Chem. Soc. 130:10199-10207.

[217] Jeroro E, Lebarbier V, Datye A, Wang Y, Vohs JM (2007) Interaction of CO with Surface PdZn Alloys. Surf. Sci. 601:5546-5554.

[218] Massalski TB (1990) Pd-Zn (Palladium-Zinc). In: Masaalski TB (ed) Binary Alloy Phase Diagrams, $2^{\text {nd }}$ edn. ASM International, Materials Park, 3068-3070.

[219] Iwasa N, Mayanagi T, Masuda S, Takezawa N (2000) Steam Reforming of Methanol over Pd-Zn Catalysts. React. Kinet. Catal. Lett. 69:355-360. 